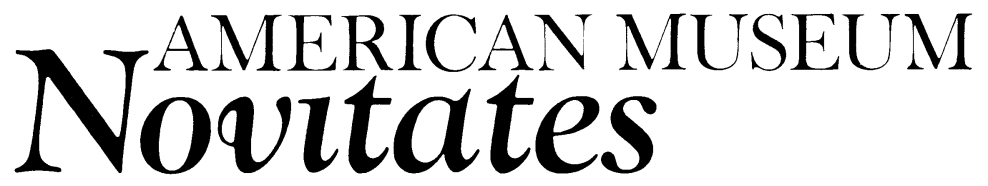

PUBLISHED BY THE AMERICAN MUSEUM OF NATURAL HISTORY CENTRAL PARK WEST AT 79TH STREET, NEW YORK, NY 10024 Number 3454, 64 pp., 22 figures, 2 tables

August 23, 2004

\title{
Cephalopods from the Cretaceous/Tertiary Boundary Interval on the Atlantic Coastal Plain, with a Description of the Highest Ammonite Zones in North America. Part 1. Maryland and North Carolina
}

\author{
NEIL H. LANDMAN, ${ }^{1}$ RALPH O. JOHNSON, ${ }^{2}$ AND LUCY E. EDWARDS ${ }^{3}$
}

\begin{abstract}
The sedimentary deposits on the Atlantic Coastal Plain in New Jersey, Delaware, Maryland, North Carolina, South Carolina, and Georgia span the Cretaceous/Tertiary boundary. We investigate the ammonites of the Severn Formation on the western and eastern shore of Chesapeake Bay, Maryland, and the Peedee Formation, North Carolina. We describe three ammonite assemblages from the Severn Formation and their associated dinoflagellates, defining three successive ammonite zones in the upper Maastrichtian. The lowest ammonite zone is the Discoscaphites conradi Assemblage Zone. It occurs near the top of the Severn Formation in Prince Georges County, Maryland, just below the Paleocene Brightseat Formation. The ammonite fauna consists of Sphenodiscus pleurisepta (Conrad, 1857), Sphenodiscus lobatus (Tuomey, 1856), Discoscaphites conradi (Morton, 1834), Discoscaphites gulosus (Morton, 1834), Jeletzkytes nebrascensis (Owen, 1852), Glyptoxoceras rugatum (Forbes, 1846), Baculites vertebralis Lamarck, 1801, and Eubaculites latecarinatus (Brunnschweiler, 1966). Dinoflagellates from a sample of matrix include Isabelidinium aff. I. cooksoniae (Alberti, 1959) Lentin \& Williams, 1977, which correlates with calcareous nannofossil Zone CC25b, indicating the lower part of the upper Maastrichtian (68.2-67.4 MaBP). The D. conradi Zone is also present in parts of the Corsicana Formation, Texas, the Prairie Bluff Chalk, Alabama and

\footnotetext{
${ }^{1}$ Division of Paleontology (Invertebrates), American Museum of Natural History (landman@amnh.org).

${ }^{2}$ Monmouth Amateur Paleontologist's Society, 57 Oceanport Avenue, West Long Branch, NJ 07764 (paleotrog@ webtv.net).

${ }^{3}$ U.S. Geological Survey, Mail Stop 926A, Reston, VA 20192 (leedward@usgs.gov).
} 


\begin{abstract}
Mississippi, the Peedee Formation, North Carolina, and the Navesink and New Egypt Formations, New Jersey. The next higher zone is the Discoscaphites minardi Assemblage Zone, which occurs in the Severn Formation approximately $6 \mathrm{~m}$ below the base of the Hornerstown Formation at Lloyd Creek, Kent County, Maryland. The ammonite assemblage is dominated by Discoscaphites minardi, n.sp., B. vertebralis, and $S$. pleurisepta, with rare specimens of Sphenodiscus sp., Discoscaphites iris (Conrad, 1858), and E. latecarinatus. A sample of dinoflagellates from the same bed as the ammonites includes Deflandrea galatea (LejeuneCarpentier, 1942) Lentin \& Williams, 1973 and Thalassiphora pelagica (Eisenack, 1954) Eisenack \& Gocht, 1960, which correlate with the Neophrolithus frequens calcareous nannofossil Zone between Subzones CC26a and CC26b, indicating the middle part of the upper Maastrichtian (66.4-66.0 MaBP). The D. minardi Zone is also present in the New Egypt Formation, New Jersey. The highest zone is the D. iris Assemblage Zone, which occurs near the top of the Severn Formation at its type locality at Round Bay, Anne Arundel County, Maryland. The ammonite assemblage is dominated by $D$. iris and E. carinatus, although elsewhere this zone also includes Pachydiscus (Neodesmoceras) mokotibensis Collignon, 1952, Pachydiscus (Pachydiscus) jacquoti jacquoti Seunes, 1890, S. lobatus, S. pleurisepta, Discoscaphites sphaeroidalis Kennedy and Cobban, 2000, and E. latecarinatus. Dinoflagellates from a sample of matrix surrounding one of the ammonites include Palynodinium grallator Gocht, 1970 and T. pelagica indicative of the $P$. grallator Zone, Tpe subzone, which correlates with the upper part of calcareous nannofossil Zone CC26b, indicating the upper part of the upper Maastrichtian (65.6-65.0 MaBP). The D. iris Zone is also present in the upper part of the Corsicana Formation, Texas, the Owl Creek Formation, Mississippi, Tennessee, and Missouri, and the New Egypt and Tinton Formations, New Jersey.
\end{abstract}

\section{INTRODUCTION}

The Cretaceous and Cenozoic strata of the Atlantic Coastal Plain crop out as a narrow, irregular belt east of the Piedmont Plateau. These outcrops have been extensively studied because they contain the Cretaceous/Tertiary boundary interval (e.g., Olsson, 1963, 1975; Olsson and Wise, 1987; Olsson et al., 1988; Jordan, 1963, 1976; Minard et al., 1969; Owens et al., 1970, 1977; Wheeler and Curran, 1974; Gallagher, 1986, 1991, 1993; Gallagher and Parris, 1985; Gallagher et al., 1986). They are especially relevant today in light of recent evidence of an asteroid impact at the end of the Cretaceous that produced a mass extinction. We have explored these outcrops with the hope of discovering ammonites to elucidate the ammonite zonation of the Maastrichtian Stage of the Atlantic Coastal Plain, as well as to provide insights into the biogeography and diversity of ammonites at the close of the Cretaceous.

For purposes of organization, we are publishing our papers as a series treating different geographic regions. In this first paper, we describe ammonites from the Peedee Formation in North Carolina and from the Severn Formation at three localities in Maryland: Prince Georges County, Kent County, and Anne Arundel County. The succession of ammonite assemblages in the Severn Formation defines three ammonite zones that span the upper Maastrichtian. The dinoflagellates associated with the ammonites permit correlation of these zones with the established biostratigraphic zonation of calcareous nannofossils.

\section{LIST OF LOCALITIES}

Numbers in parentheses indicate U.S. Geological Survey Paleobotanical localities (fig. 1).

AMNH loc. 3252 (R6235). Upper part of Severn Formation, cutbanks along Lloyd Creek, $0.9 \mathrm{mi}(1.4 \mathrm{~km})$ east-northeast of Stillpond, Kent County, Maryland.

AMNH loc. 3260 (R6370). Upper part of Severn Formation, exposures along banks of a tributary of Cattail Brook, $0.5 \mathrm{mi}(0.8 \mathrm{~km})$ south of the intersection of Sheriff and Brightseat roads, near Brightseat, Prince Georges County, Maryland.

U.S. Geological Survey Paleobotanical loc. R6374. Upper part of Severn Formation, presumed to be from the western shore of the Severn River at Round Bay, Anne Arundel County, Maryland.

AMNH loc. 3345 (R6234A-D). Top of 

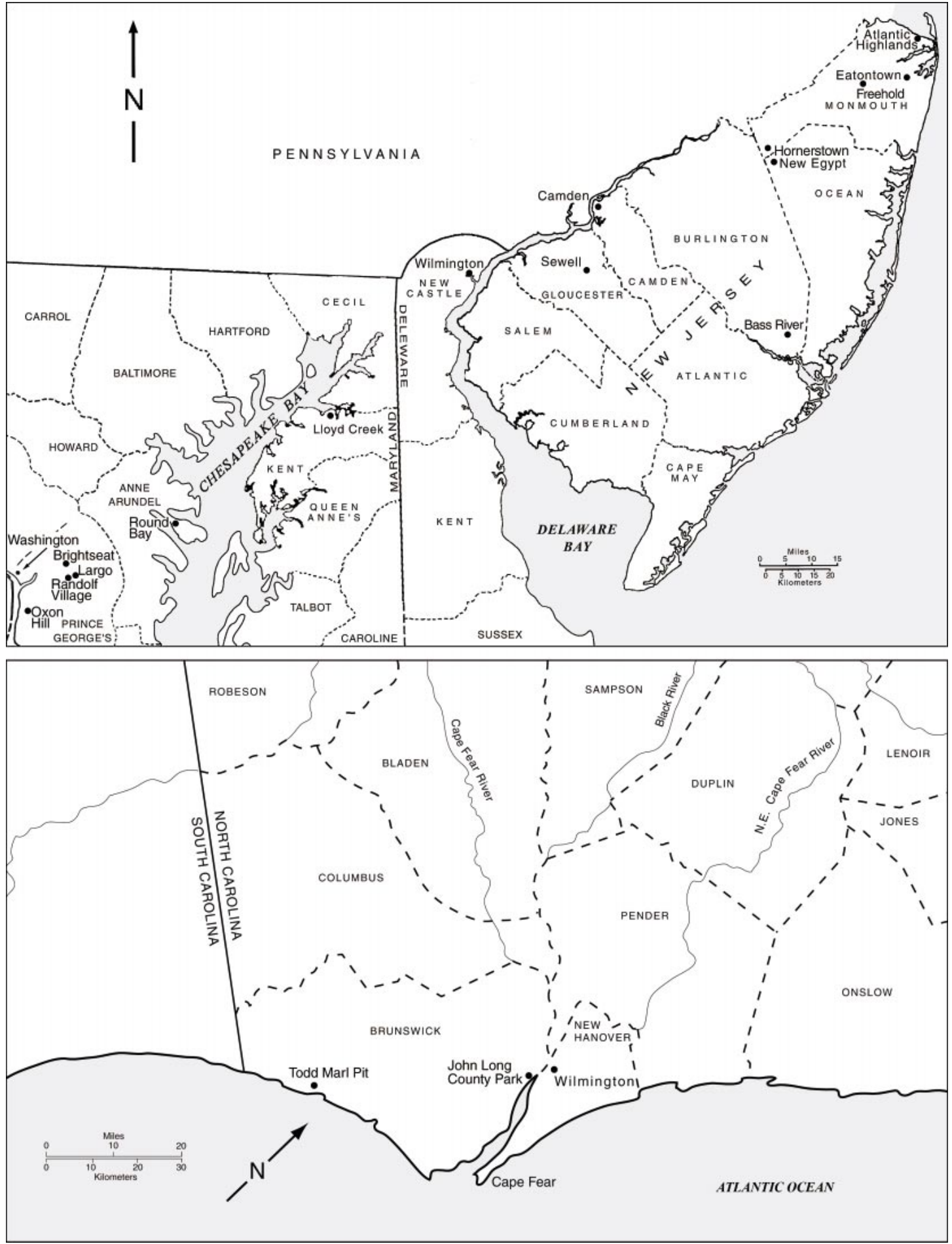

Fig. 1. Maps of parts of New Jersey, Delaware, Maryland, and North Carolina showing localities mentioned in the text. 
New Egypt Formation and bottom of Hornerstown Formation, Parkers Creek, $0.3 \mathrm{~km}$ east of Rt. 35, northwest of Eatontown, Monmouth County, New Jersey.

AMNH loc. 3346 (R6234E). Upper part of New Egypt Formation, approximately 1.5-2 $\mathrm{m}$ below the base of the Hornerstown Formation, Parkers Creek, $0.1 \mathrm{~km}$ east of Rt. 35, northwest of Eatontown, Monmouth County, New Jersey.

Upper part of Peedee Formation, Todd Marl Pit off Todd Road, approximately $2 \mathrm{~km}$ west of the Shalotte River, Brunswick County, North Carolina.

Upper part of Peedee Formation, John D. Long County Park, Rt. 33, $1.1 \mathrm{mi}(1.8 \mathrm{~km})$ south of Rt. 17, Brunswick County, North Carolina.

U.S. Geological Survey loc. 25423. Owl Creek Formation, bluffs on Owl Creek, $3 \mathrm{mi}$ $(4.8 \mathrm{~km})$ northeast of Ripley, secs. 7 and 8, T4S, R4E, Tippah County, Mississippi.

\section{SEVERN FORMATION}

OVERVIEW

The Severn Formation is named for exposures on the Severn River at Round Bay on the western shore of Chesapeake Bay, Anne Arundel County, Maryland (Minard et al., 1977). The name Severn Formation replaces the name Monmouth Formation previously proposed by Clark (1916) and Clark et al. (1897). The unit is entirely marine and very fossiliferous and consists of dark gray, finely micaceous, sparingly glauconitic, quartz sand (fig. 2). The formation crops out as a narrow, irregular band that extends southwest-northeast (Glaser, 1968) from Prince Georges County, Maryland, to New Castle County, Delaware (Minard et al., 1977). The formation thins to the southwest; it is a maximum of $24 \mathrm{~m}$ thick on the eastern shore of Chesapeake Bay (Minard et al., 1977), $12.6 \mathrm{~m}$ thick at its type locality at Round Bay on the western shore of Chesapeake Bay (Minard, 1980), and approximately $10 \mathrm{~m}$ thick in the Brightseat area near the type locality of the Brightseat Formation (Owens et al., 1977).

Brouwers and Hazel (1978) interpreted the Severn Formation as having been deposited in the Salisbury Embayment, which covered parts of southern Delaware, eastern Maryland, and northeastern Virginia. It contains a rich molluscan fauna, and in areas that have not suffered extensive groundwater leaching, the fossils preserve their original aragonitic shell (Hartstein and Decina, 1986; Kennedy et al., 1997; Kuehne, 1999). It also contains an abundant scrap fauna of marine vertebrates, including fish, sharks, sea turtles, plesiosaurs, mosasaurs, and crocodiles, as well as terrestial and fluviatile vertebrates, including soft-shelled turtles and dinosaurs, indicating that the site of deposition was relatively nearshore (Baird, 1986; Hartstein and Decina, 1986).

The Severn Formation has been correlated with the Navarroan Provincial Stage (Murray, 1961; Brouwers and Hazel, 1978). This stage is approximately equivalent to the whole of the Maastrichtian Stage as shown by Pessagno (1969), but Brouwers and Hazel (1978) have pointed out that the upper and lower boundaries of the Navarroan Provincial Stage may not coincide exactly with those of the Maastrichtian. Many studies have refined the age of the Severn Formation on the basis of a variety of micro- and macrofossils. However, these studies, which we review below, are sometimes difficult to interpret because of changes in biostratigraphic usage since the studies were completed. Our discussion of the Severn Formation is divided into three parts, covering, in sequential order, Prince Georges, Kent, and Anne Arundel Counties, Maryland.

\section{Prince Georges County}

\section{STRATIGRAPHY AND PALEONTOLOGY}

Thanks to roadwork and construction activities in the past 30 years, many new outcrops of the Severn Formation have been exposed in Prince Georges County, Maryland, and have provided the impetus for renewed research activity. These outcrops include localities near Brightseat (loc. 1, Brouwers and Hazel, 1978; loc. A, Baird, 1986), Landover (loc. 2, Brouwers and Hazel, 1978; loc. B, Baird, 1986), Largo (loc. G, Baird, 1986), Oxon Hill (loc. F, Baird, 1986), and Randolph Village (loc. 3a, Brouwers and Hazel, 1978; loc. C, Baird, 1986).

A composite stratigraphic section of the 


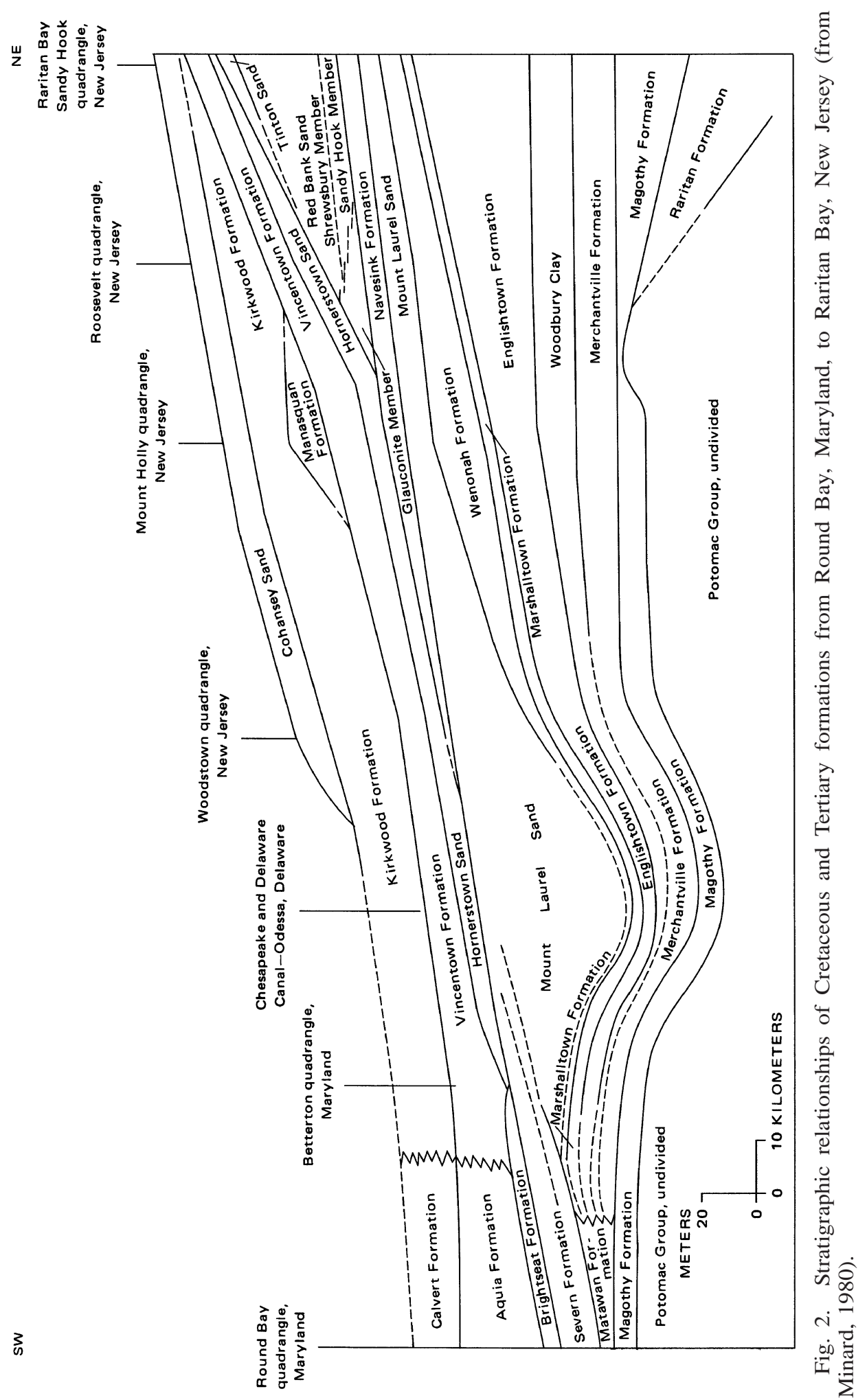



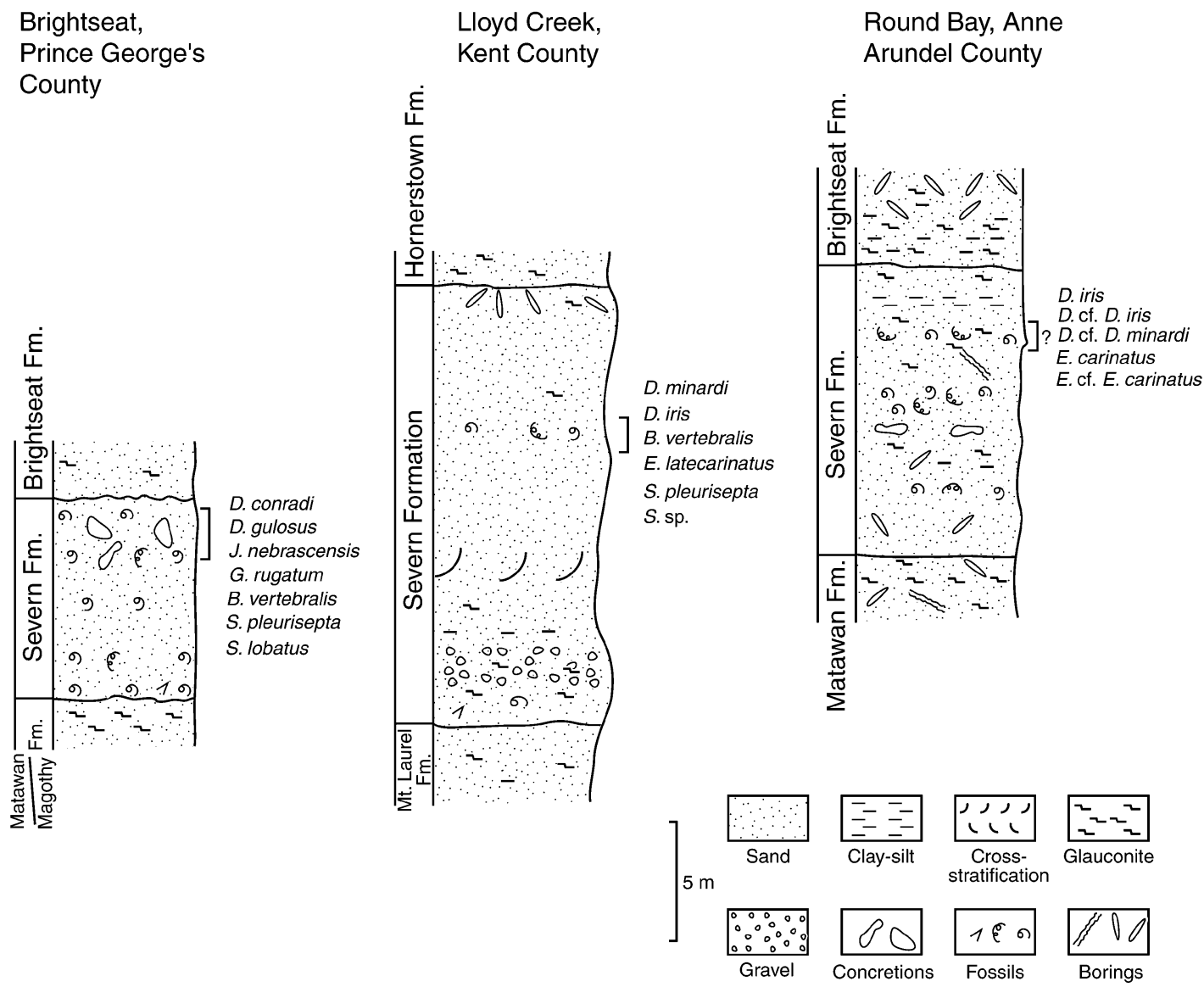

Fig. 3. Generalized stratigraphic sections of the Severn Formation at three sites in Maryland. The sections are arranged so that the ammonite assemblages (= zones) appear in ascending stratigraphic order from left to right. The Brightseat section is based on Owens et al. (1977: fig. 61), the Lloyd Creek section on Minard (1974: pl. 1; 1980) and Minard et al. (1977), and the Round Bay section on Minard (1980: pl. 1). The ammonites from Round Bay were probably collected from a site $2-3 \mathrm{~km}$ southwest of the type locality on the west side of the Severn River. According to Owens et al. (1977: fig. 61), this site is similar to the type locality. The stratigraphic position of the ammonites at Round Bay is shown with a question mark because the position is inferred based on the associated dinoflagellates with reference to the biostratigraphic zonation of the Severn Formation documented by Benson (1976) and Firth (1987).

Severn Formation in Prince Georges County is illustrated in figure 3. The Severn Formation is approximately $10 \mathrm{~m}$ thick and is unconformably underlain by either the Magothy or Matawan Formation, depending on the site, and is unconformably overlain by either the Brightseat or Aquia Formation, also depending on the site (Cooke, 1952; Glaser, 1968; Whitney, 1984). The upper 2$3 \mathrm{~m}$ of the Severn Formation contain a rich molluscan fauna.

The stream-bank exposures along the trib- utary of Cattail Branch, near Brightseat (near AMNH loc. 3260, equivalent to Brightseat locality, Gardner, 1916; loc. 1, Brouwers and Hazel, 1978) have been described by Kuehne (1999). The sediments consist of dark gray, micaceous, sandy clay, containing large, rounded, sideritic concretions. Fossils occur in the upper $2-3 \mathrm{~m}$ at this site and are preserved with original shell material both in the clay and in the concretions. The fauna is very rich in molluscs, consisting of 46 bivalve species, 54 gastropod species, and 8 cepha- 
lopod species (Kuehne, 1999: 77-78). Owens et al. (1977) noted reworked Cretaceous fossils at the base of the overlying Brightseat Formation.

Hartstein and Decina (1986) described a nearby outcrop of the Severn Formation at a construction site of an industrial park at the southeast quadrant of the junction of Interstate 95 and Landover Road. The excavations exposed up to $15 \mathrm{ft}(4.6 \mathrm{~m})$ of the Severn Formation. Most fossils are well preserved and occur in medium to large concretions 2$6 \mathrm{ft}(0.6-1.8 \mathrm{~m})$ below the top of the formation. Hartstein and Decina (1986: 88, Table 1) stated that "nearly 60 of the more than 100 species of molluscs described from the Severn Formation were relatively common at this site."

Kuehne (1999: 78) described stream-bank exposures at the head of a small ravine 1.5 mi $(2.4 \mathrm{~km})$ south of Oxon Hill (site F, Baird, 1986), approximately $15 \mathrm{~km}$ southwest of Brightseat. The Severn Formation consists of $2.8 \mathrm{~m}$ of medium gray, micaceous, sandy clay overlain by $3.8 \mathrm{~m}$ of the Aquia Formation. Original shell material is preserved in the clay and in the concretions. The fauna is less diverse than in the Brightseat area and consists of 37 bivalve species, 13 gastropod species, 1 scaphopod species, and 3 cephalopod species.

The ammonites from the upper part of the Severn Formation in Prince Georges County (fig. 4) have been described by Clark (1916: pl. 12, fig. 1; pl. 13, fig. 10), Hartstein and Decina (1986: pl. 2, figs. 14-16, 18), Landman and Waage (1993: fig. 133), and Kennedy et al. (1997: figs. 1-24). They are abundant and well preserved and consist of Sphenodiscus pleurisepta (Conrad, 1857), Sphenodiscus lobatus (Tuomey, 1856), Discoscaphites conradi (Morton, 1834), Discoscaphites gulosus (Morton, 1834), Jeletzkytes nebrascensis (Owen, 1852), Baculites vertebralis Lamarck, 1801, Eubaculites latecarinatus (Brunnschweiler, 1966), and Glyptoxoceras rugatum (Forbes, 1846).

\section{Age And Correlation}

The ammonites from the Severn Formation in Prince Georges County represent the D. conradi Assemblage Zone of the Gulf and
Atlantic Coastal Plain (Cobban and Kennedy, 1995; Kennedy et al., 1997). Kennedy et al. (1997) correlated this assemblage zone with part or all of the Belemnitella junior and $\mathrm{Be}$ lemnella kazimiroviensis Zones in the northwest European succession (fig. 5). According to Christensen (1996), as reviewed by Burnett (1998a), these zones are approximately equivalent to the whole of the upper Maastrichtian. Kennedy et al. (1997) concluded "that the Severn Formation occupies a horizon high in the Maastrichtian, but slightly below the top of the stage ..."'.

Sohl (1977: text-fig. 5) and Sohl and Koch (1984) studied the molluscs, notably the gastropods, from several sites in Prince Georges County near the top of the Severn Formation (fig. 4). They identified the Haustator bilira Assemblage Zone of the Gulf and Atlantic Coastal Plain. According to Sohl and Koch (1984), this zone includes all deposits on the Coastal Plain above the base of the Globotruncana gansseri Subzone of Pessagno (1969). Following the interpretation of Schönfeld and Burnett (1991: fig. 7), this interval (i.e., Cretaceous deposits above the $G$. gansseri Subzone) is approximately equivalent to the entire upper Maastrichtian (fig. 5). Owens et al. (1977) pointed out that the age of the lower part of the Severn Formation in Prince Georges County is more poorly constrained. They reported Belemnitella near the base of the formation in one outcrop in the Lanham quadrangle, indicating, according to them, an older faunal assemblage.

Brouwers and Hazel (1978) studied the ostracodes of the Severn Formation from six localities in Prince Georges County (fig. 4). They analyzed 10 samples near Brightseat from the base to the top of the formation, that is, from the contact with the underlying Magothy Formation to the contact with the overlying Brightseat Formation. They treated the ostracodes from all six localities as a single assemblage and compared it with the biostratigraphic distribution of ostracodes in correlative formations on the Gulf and Atlantic Coastal Plain. They concluded that the Severn Formation in Prince Georges County correlates with part of the Globotruncana gansseri Subzone of Pessagno (1969), which, in terms of today's usage, is approximately equivalent to the lower part of the 

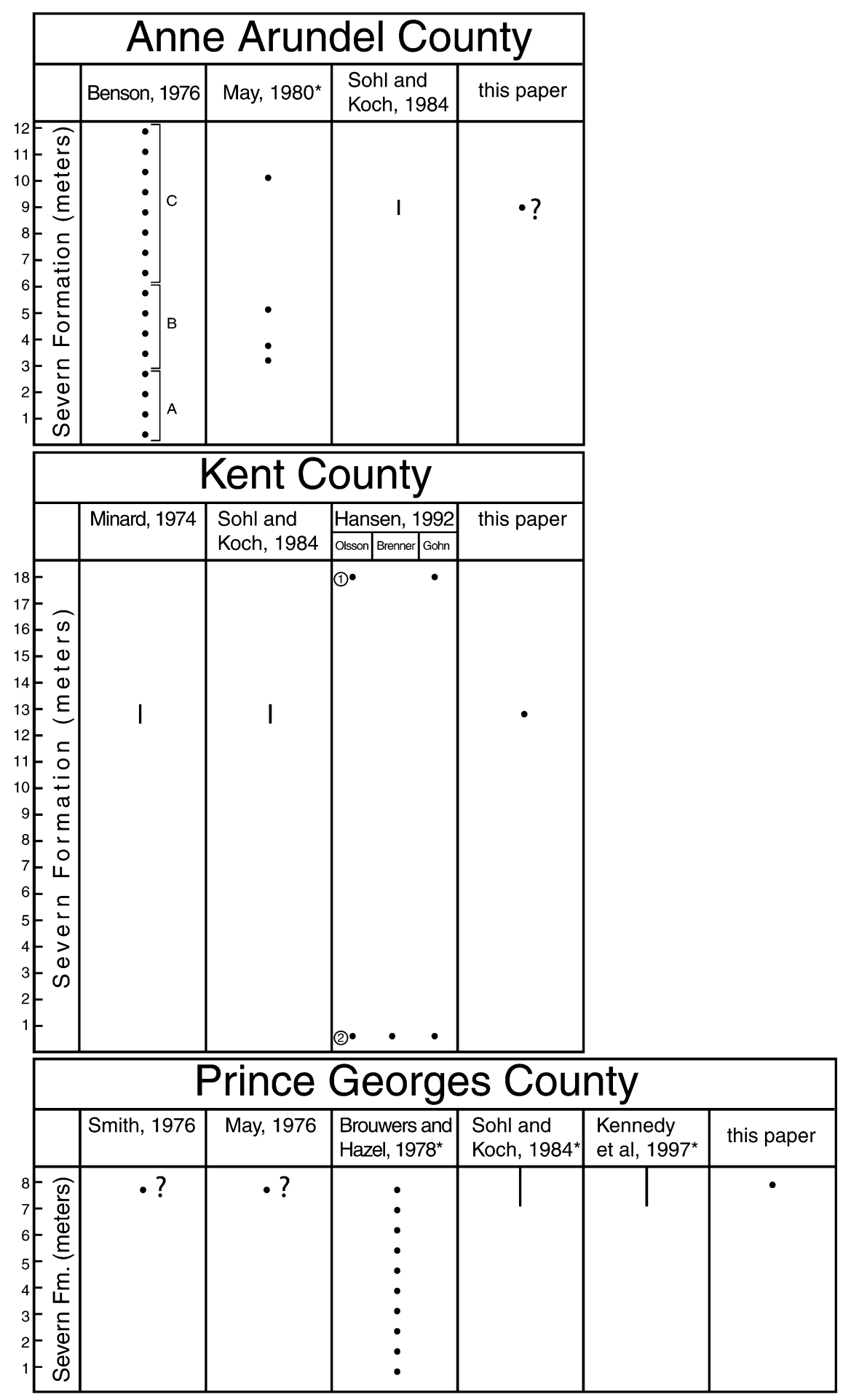

* multiple localities 
upper Maastrichtian (Schönfeld and Burnett, 1991) (fig. 5).

Brouwers and Hazel (1978) cited two other studies that corroborated their results. C.C. Smith (personal commun., 1976, in Brouwers and Hazel, 1978) analyzed nannofossils from one locality in the Severn Formation in Prince Georges County (locality 3b, Brouwers and Hazel, 1978), presumably from the upper part of the unit (fig. 4). He suggested that the Severn Formation correlates with the G. gansseri Subzone of Pessagno (1969), that is, the lower upper Maastrichtian (fig. 5). F.E. May (personal commun., 1976, in Brouwers and Hazel, 1978) analyzed the dinoflagellates from the same locality as Smith and concluded that the formation correlates with the Belemnitella lanceolata-B. occidentalis Zone and/or with the lower part of the $B$. occidentalis Zone of the type Maastrichtian (figs. 4, 5). According to Brouwers and Hazel (1978), citing Berggren (1964), this zone is approximately equivalent to the $G$. gansseri Subzone of Pessagno (1969), that is, the lower upper Maastrichtian.

\section{New Observations}

A grain size analysis of the sediments from AMNH loc. 3260 near Brightseat, Prince Georges County, reveals that nearly one-half $(48 \%)$ of the sediments are sand, almost evenly divided between very fine $(0.0625 \mathrm{~mm} \leq x<0.125 \mathrm{~mm})$ and fine $(0.125 \mathrm{~mm} \leq x<0.25 \mathrm{~mm})$ grain fractions. Quartz is the dominant mineral (52\%), with glauconite and mica representing much smaller proportions, $6 \%$ and $5 \%$, respectively.

The matrix in the body chamber of AMNH 47478, a specimen of Sphenodiscus lobatus from AMNH loc. 3260 (R6370), was analyzed for dinoflagellates (table 1, figs. 6, 7). The preservation is good, the diversity is moderate, and no single species dominates. The flora notably includes Isabelidinium aff.
I. cooksoniae (Alberti, 1959) Lentin \& Williams, 1977.

\section{Lloyd CReek, Kent County}

\section{Stratigraphy and Paleontology}

Minard (1974) studied the stratigraphy of the Betterton quadrangle in Kent County, Maryland, on the eastern shore of Chesapeake Bay, where he identified what he called the Mount Laurel Sand. He described it as a thick unit of glauconitic quartz sand lying between the Marshalltown Formation below and the Hornerstown Formation above. He described the Mount Laurel/Hornerstown formational contact as unconformable and spanning the Cretaceous/Tertiary boundary. Reminiscent of Hornerstown contacts elsewhere, Minard (1974: 11) wrote that "The green, very glauconitic Hornerstown lies directly on the brown to gray, sparingly glauconitic quartz sand of the Mount Laurel. In some outcrops, glauconite filled borings extend downward from the basal Hornerstown into the Mount Laurel." In a core-hole drilled near Chesterville, Kent County, Hansen (1992) reported that the contact was sharp with 0.5 in. $(1.3 \mathrm{~cm})$ of relief.

Subsequently, Minard et al. (1977) and Minard (1980) reinterpreted the upper part of the Mount Laurel Formation in the Betterton quadrangle as part of the Severn Formation (fig. 2). According to Minard et al. (1977), the Severn Formation is approximately $24 \mathrm{~m}$ thick in this area and is bounded below by very coarse quartz sand with granules and small pebbles (fig. 3). In contrast, Hansen (1992) reported a thickness of only $14 \mathrm{ft}$ (4.8 $\mathrm{m})$ in his core near Chesterville.

Minard (1974) noted the presence of fossiliferous beds of Maastrichtian age, which occur locally at the top of the Severn Formation, especially in the northeastern part of the Betterton quadrangle (figs. 4, 5). He described these beds as medium gray to medi-

Fig. 4. Approximate stratigraphic positions of samples from the Severn Formation in Prince Georges, Kent, and Anne Arundel Counties, Maryland, used in various studies to determine the biostratgraphic position of the Severn Formation. The samples are plotted on a generalized stratigraphic section for each area (fig. 3). 

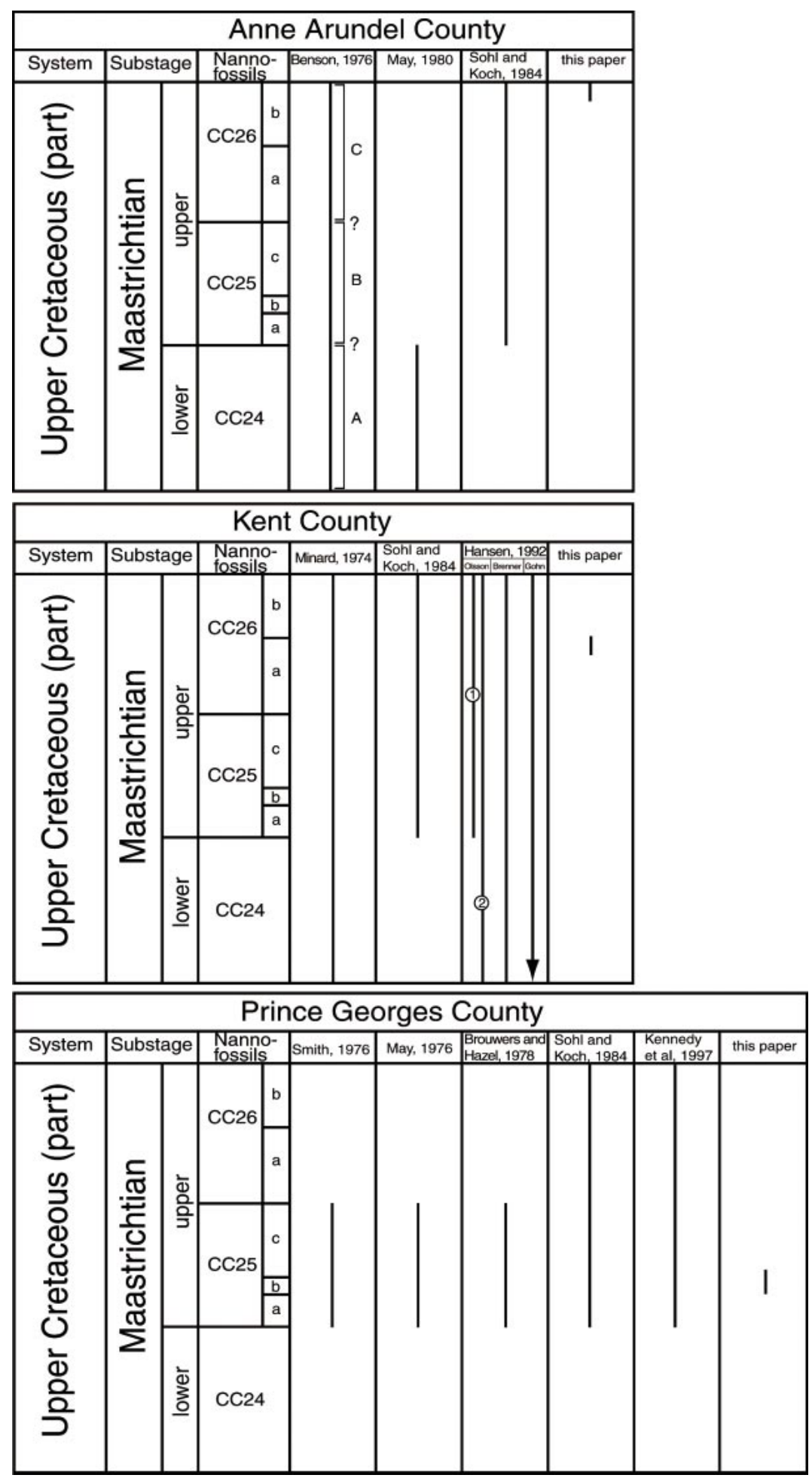
um dark gray, silty to clayey, glauconitic, quartz sand with some mica and feldspar. The contact with the overlying Hornerstown Formation was not visible at these outcrops and he did not indicate the distance of these beds below the base of the Hornerstown Formation. However, Minard (1974, pl. 1) illustrated a fossiliferous layer approximately 6 $m$ below the base of the Hornerstown Formation in his stratigraphic column, which presumably represents this horizon.

Minard (1974) reported that fossils were abundant and included bivalves such as $\mathrm{Cu}$ cullaea and Cardium, gastropods such as Haustator bilira (Stephenson, 1941), and ammonites. N.F. Sohl (personal commun., 1971, in Minard, 1974) compiled a list of 26 molluscan species including Baculites sp., Discoscaphites sp., Sphenodiscus sp., and Eutrephoceras sp. He described Baculites sp. as common (6-25 specimens) and the other ammonite species as rare (1-5 specimens). Sohl and Koch (1984: 165) subsequently assembled a faunal list of 30 molluscan species from this same site, partly reprinted in Kuehne (1999), including 19 bivalve species, 7 gastropod species, 1 scaphopod species, and 3 cephalopod species. Kuehne (1999: 38) wrote that "The bivalves Agerostrea, Cucullaea, and Syncyclonema are dominant. Common subsidiaries include the bivalves Crassatella, Veniella, Cubitostrea, and the ammonite Baculites."

\section{Age And Correlation}

Sohl and Koch (1984) interpreted the molluscan fauna in the Betterton quadrangle as representing the Haustator bilira Assemblage Zone, which lies above the base of the G. gansserri Subzone of Pessagno (1969). This interval is approximately equivalent to the whole of the upper Maastrichtian (figs. 4, $5)$.

Hansen (1992) reported three studies based on a core-hole through the Severn For- mation at Chesterville, Kent County. Two samples were analyzed, one from near the bottom, and the other from near the top of the formation (fig. 4). Olsson (in Hansen, 1992: appendix D) studied the foraminifera and assigned the upper sample to the upper Maastrichtian and the lower sample to the Maastrichtian (fig. 5). Brenner (in Hansen, 1992: appendix C) studied the dinoflagellates, pollen, and spores, and assigned the lower sample to the Maastrichtian (the upper sample was barren) (fig. 5). Gohn (in Hansen, 1992: appendix B) studied the ostracodes and concluded that both samples ranged from the upper Campanian to the Maastrichtian (fig. 5).

\section{New ObSERVATIOns}

The exposures at Lloyd Creek consist of approximately $2 \mathrm{~m}$ of clayey to silty, glauconitic, quartz sand. A grain size analysis reveals that the sediments are slightly sandier than at Brightseat, Prince Georges County. Two-thirds $(67 \%)$ of the sediments are sand, approximately evenly divided between fine and medium grain fractions. Quartz is the dominant mineral (78\%), with glauconite representing $7 \%$ and mica $1 \%$.

Macrofossils are relatively abundant and occur in a mottled interval $12 \mathrm{~cm}$ thick. The fossils are internal molds although some preserve traces of shelly iridescence. The collection (USNM, AMNH, and MAPS) consists of 32 specimens of Discoscaphites minardi, n.sp., most of which are pieces of body chambers, although a few retain parts of phragmocones; 1 fragmentary specimen of D. iris (Conrad, 1858); 30 specimens of Baculites vertebralis Lamarck, 1801; 1 specimen of Eubaculites latecarinatus (Brunnschweiler, 1966); 4 fragments of Sphenodiscus pleurisepta (Conrad, 1857); and 7 pieces of Sphenodiscus sp., which are too broken for specific identification.

We analyzed a sample of the matrix as-

$\leftarrow$

Fig. 5. Biostratigraphic position of the Severn Formation according to various authors, based on the samples shown in figure 4. We have interpreted the results of these studies in terms of today's biostratigraphic usage, even if they were not expressed that way originally, and may therefore have introduced errors into the interpretation. 
TABLE 1

Occurrences of Dinocyst Taxa from the Severn Formation, Marylanda

\begin{tabular}{|c|c|c|c|}
\hline Taxon & $\begin{array}{c}\text { Brightseat } \\
3260 \\
(\mathrm{R} 6370)\end{array}$ & $\begin{array}{c}\text { Lloyd Ck. } \\
3252 \\
\text { (R6235) }\end{array}$ & $\begin{array}{c}\text { Round } \\
\text { Bay } \\
\text { R6374 }\end{array}$ \\
\hline Alisogymnium/Dinogymnium spp. & & $\mathrm{X}$ & \\
\hline ? Andalusiella rhombohedra of Edwards et al. (1984) & & $\mathrm{X}$ & \\
\hline Areoligera senonensis Lejeune-Carpentier, 1938, species complex & $\mathrm{X}$ & & \\
\hline Areoligera/Glaphyrocysta complex & $\mathrm{X}$ & $\mathrm{X}$ & \\
\hline Cerodinium striatum/diebelii complex & & $\mathrm{X}$ & \\
\hline Circulodinium distinctum (Deflandre \& Cookson, 1955) Jansonius, 1986, species complex & & $\mathrm{X}$ & \\
\hline Conneximura fimbriata May, 1980 & $\mathrm{X}$ & & \\
\hline Cordosphaeridium fibrospinosum Davey \& Williams, 1966 & $\mathrm{X}$ & & $\mathrm{X}$ \\
\hline Cribroperidinium spp. & $\mathrm{X}^{\mathrm{b}}$ & $\mathrm{X}$ & $\mathrm{X}^{\mathbf{b}}$ \\
\hline Cyclopsiella? sp. of Edwards et al. (1984) & $\mathrm{X}$ & $\mathrm{X}$ & \\
\hline Deflandrea galatea (Lejeune-Carpentier, 1942) Lentin \& Williams, 1973 & $\mathrm{X}$ & $\mathrm{X}$ & $\mathrm{X}$ \\
\hline Disphaerogena carposphaeropsis Wetzel, 1933 (= Cyclapophysis monmouthensis) & & & $\mathrm{X}$ \\
\hline Fibradinium aff. F. annetorpense Morgenroth, 1968 & & $\mathrm{X}$ & \\
\hline Fromea fragilis (Cookson \& Eisenack, 1962) Stover \& Evitt, 1978 & $\mathrm{X}$ & $\mathrm{X}$ & \\
\hline $\begin{array}{l}\text { Glaphyrocysta expansa (Corradini, 1973) Roncaglia \& Corradini, } 1997 \\
\quad(?=\text { G. perforata sensu Schiøler et al., 1997) }\end{array}$ & & & $\mathrm{X}$ \\
\hline Hafniasphaera fluens Hansen, 1977 & $\mathrm{X}$ & $\mathrm{X}$ & $\mathrm{X}$ \\
\hline Hystrichokolpoma ? sp. & & $\mathrm{X}$ & \\
\hline Hystrichosphaeridium tubiferum (Ehrenberg, 1838) Deflandre, 1937 & & $?$ & $\mathrm{X}$ \\
\hline Impagidinium sp. & & $\mathrm{X}$ & \\
\hline Isabelidinium aff. I. cooksoniae (Alberti, 1959) Lentin \& Williams, 1977 & $\mathrm{X}$ & & \\
\hline Kleithriasphaeridium truncatum (Benson, 1976) Stover \& Evitt, 1978 & $\mathrm{X}$ & & $\mathrm{X}$ \\
\hline Microdinium cretaceum Slimani, 1994 & & $\mathrm{X}$ & \\
\hline Operculodinium/Fibrocysta complex & $\mathrm{X}$ & $\mathrm{X}$ & $\mathrm{X}$ \\
\hline Operculodinium centrocarpum (Deflandre \& Cookson, 1955) Wall, 1967, sensu lato & & $\mathrm{X}$ & \\
\hline Palaeocystodinium australinum (Cookson, 1965) Lentin \& Williams, 1976 & & $\mathrm{X}$ & \\
\hline Palaeoperidinium sp. & $\mathrm{X}$ & $\mathrm{X}$ & \\
\hline Palynodinium grallator Gocht, 1970 & & & $\mathrm{X}$ \\
\hline Piercites pentagonum (May, 1980) Habib \& Drugg, 1987 & $\mathrm{X}$ & & $\mathrm{X}$ \\
\hline Spinidinium ? clavus Harland, 1973 & & $\mathrm{X}$ & \\
\hline Spiniferites spp. & $\mathrm{X}$ & $\mathrm{X}$ & $\mathrm{X}$ \\
\hline Systematophora placacantha (Deflandre \& Cookson, 1955) Davey et al., 1969 & & $\mathrm{X}$ & \\
\hline Tanyosphaeridium xanthiopyxides (Wetzel, 1933) Stover \& Evitt, 1978 & & $\mathrm{X}$ & $\mathrm{X}$ \\
\hline Thalassiphora pelagica (Eisenack, 1954) Eisenack \& Gocht, 1960 & & $\mathrm{X}$ & $?$ \\
\hline Xenikoon australis Cookson \& Eisenack, 1960 & & $\mathrm{X}$ & \\
\hline misc. cladopyxidiaceans & & $\mathrm{X}$ & \\
\hline misc. small peridiniceans & $\mathrm{X}$ & $\mathrm{X}$ & $\mathrm{X}$ \\
\hline
\end{tabular}

${ }^{a}$ AMNH location 3260 (R6370), Brightseat, Prince Georges County; AMNH location 3252 (R6235), Lloyd Creek, Kent County; and U.S. Geological Survey Paleobotanical location R6374, Round Bay, Anne Arundel County.

bIncludes C. edwardsi/wetzelii/ventriosum complex.

sociated with the ammonites for dinoflagellates (U.S. Geological Survey Paleobotanical no. R6235). The species (table 1, figs. 6, 7) notably include Deflandrea galatea (Lejeune-Carpentier, 1942) Lentin \& Williams, 1973. The preservation is good, the diversity is high, and no single species dominates.

\section{Round bay, Anne Arundel County}

\section{Stratigraphy AND PALEONTOlogy}

The type locality of the Severn Formation is on the east bank of the Severn River at Round Bay, $0.64 \mathrm{~km}$ north of Swan Point, Anne Arundel County, Maryland (Minard, 
1980). The Severn Formation is $12.6 \mathrm{~m}$ thick and disconformably overlies the Matawan Formation and underlies the Brightseat Formation (fig. 3). Minard (1980) noted that the upper boundary represents a paraconformity. According to Minard (1980: 10), the exposure "consists of dark- to medium-gray, clayey and silty, poorly sorted, mostly fine- to medium-grained sparsely glauconitic quartz sand containing a fair amount of both very fine and coarse to very coarse quartz grains and granules, colorless mica, and carbonaceous matter." Minard (1980: 12) recorded a slight increase in grain size toward the middle of the section, culminating in coarse to very coarse quartz grains and granules. He also noted a slight decrease in the percentage of glauconite upward toward the middle of the section, followed by an increase in the percentage toward the top. Discontinuous layers of montmorillonitic clay are common in an interval approximately $30 \mathrm{~cm}$ thick 1 $\mathrm{m}$ below the top of the formation.

Minard (1980) stated that three fossiliferous beds are locally present. As shown in his stratigraphic section, they occur at $3 \mathrm{~m}$ above the bottom, $7 \mathrm{~m}$ above the bottom, and 9.6 $\mathrm{m}$ above the bottom ( $=3 \mathrm{~m}$ below the top). Owens et al. (1977: fig. 61) illustrated a generalized stratigraphic section from this site showing these same three beds but at slightly different levels: $3 \mathrm{~m}$ above the bottom, 7.5 $\mathrm{m}$ above the bottom, and $10 \mathrm{~m}$ above the bottom ( $=4 \mathrm{~m}$ below the top). According to Minard (1980: 12), the fossils "are mostly iron-oxide coated casts and molds in the clayey sand; a few outcrops contain calcareous shells."

Sohl and Koch (1984: 164) described another locality (location no. 400) from the upper part of the Severn Formation at Round Bay, Anne Arundel County. This locality is on the western shore of the Severn River approximately $2-3 \mathrm{~km}$ southwest of the type locality, although the coordinates given are not precise enough to locate it exactly. They observed a fossiliferous horizon $10 \mathrm{ft}(3 \mathrm{~m})$ above sea level yielding internal molds in a matrix of dark gray fine sand, with glauconite and mica. They listed 31 specimens of Baculites (Eubaculites) carinatus, 25 specimens of Baculites sp., 40 specimens of Discoscaphites conradi var., and 3 specimens of
Sphenodiscus sp. Owens et al. (1977: fig. 61) illustrated a section of presumably this same site showing a bed labeled with Discoscaphites conradi and Baculites undatus near the middle of the formation, approximately $2.9 \mathrm{~m}$ above the point of exposure and 4.6 $\mathrm{m}$ below the top.

Benson (1976) studied the dinoflagellates of the Severn Formation at Round Bay on the western shore of the Severn River approximately $2-3 \mathrm{~km}$ southwest of the type locality, presumably the same site described by Sohl and Koch (1984). Based on Benson's stratigraphic section of this site, the Severn Formation is approximately $10 \mathrm{~m}$ thick. It is identical to that at the type locality, including the clay layer near the top of the unit, but is missing the lower $2.5 \mathrm{~m}$ of the formation that are exposed at the type locality.

\section{Age And Correlation}

Sohl and Koch interpreted the molluscan fauna at Round Bay as representing the Haustator bilira Assemblage Zone. This is approximately equivalent to the upper Maastrichtian (fig. 5).

Benson (1976) analyzed 16 samples from the Severn Formation at Round Bay and defined three informal biostratigraphic zones, $\mathrm{A}, \mathrm{B}, \mathrm{C}$, in ascending order, based on the distribution of dinoflagellates (figs. 4, 5). Zone A comprises the bottom $2 \mathrm{~m}$ of the formation, Zone $\mathrm{B}$ the overlying $2.5 \mathrm{~m}$, and Zone $\mathrm{C}$ the rest of the formation $(\sim 5 \mathrm{~m})$. Firth (1987, text-fig. 7) interpreted Benson's Zone A as lower Maastrichtian and the upper one-half of Zone C as upper Maastrichtian; he stated that the exact boundary between the lower and upper Maastrichtian was difficult to pinpoint but lay somewhere between the top of Zone A and the middle of Zone C.

May (1980) studied the dinoflagellates and acritarchs from the Severn Formation from two sites in the Round Bay area comprising four samples from the upper and lower part of the formation (figs. 4, 5). Based on a comparison with the biostratigraphic distribution of these fossils in New Jersey, he concluded that the samples, as a whole, were early Maastrichtian in age, although the meaning of this assignment in terms of today's usage is not entirely clear. 


\section{New Observations}

The ammonites we describe were found in a drawer of Norman F. Sohl's material at the U.S. National Museum. The only label in the entire drawer was Round Bay, Maryland. This may represent the type locality or, more likely, the opposite shore on the banks of the Severn River approximately 2-3 km southwest of the type locality. The dinoflagellates from the matrix of one of the ammonites (see below) indicate that the fossils are probably from the upper part of the Severn Formation, according to the measured section given by Benson (1976). In all likelihood, the ammonites are from the same fossiliferous horizon described by Sohl and Koch (1984) and Owens et al. (1977) approximately $4 \mathrm{~m}$ below the top of the formation. However, it is unclear if all of the ammonites are from this same horizon, because only one specimen was sampled for dinoflagellates.

The matrix consists of dark gray to black clayey sand with pieces of lignite. The ammonites are internal molds composed of the same material as the matrix itself and are mostly fragments. Three small pieces of scaphites were in a separate box. They are free of matrix and have a pinkish-buff appearance, and one is stained with iron oxide.

A grain size analysis of the matrix attached to USNM 525323 reveals that the percentage of sand $(45 \%)$ is more similar to that at Brightseat (48\%) than that at Lloyd Creek $(67 \%)$. Most of the sand falls in the very fine grain fraction. Quartz is the dominant mineral $(46 \%)$ with lesser, nearly equal percentages of glauconite $(21 \%)$ and mica $(22 \%)$.

We identified six specimens of Discoscaphites iris (Conrad, 1858), one specimen of Discoscaphites cf. D. iris, one specimen of Discoscaphites cf. D. minardi, n.sp., one specimen of Eubaculites carinatus (Morton,
1834), and two specimens of Eubaculites cf. E. carinatus.

The matrix associated with USNM 525323 was analyzed for dinoflagellates (U.S. Geological Survey Paleobotanical no. R6374). The preservation is good, the diversity is moderate, and no single species dominates. The flora is listed in table 1 and illustrated in figures 6 and 7 and notably includes $P a$ lynodinium grallator Gocht, 1970 and Thalassiphora pelagica (Eisenack, 1954) Eisenack \& Gocht, 1960.

\section{PeEdeE Formation}

The Peedee Formation is a thick marine sequence that crops out on the Carolina Coastal Plain and is widespread in the subsurface (Stephenson, 1923). It unconformably overlies the Donoho Creek Formation and unconformably underlies deposits that range in age from Paleocene to Holocene, depending on the locality (Wheeler and Curran, 1974). It consists of dark greenish to gray, sparingly micaceous and glauconitic, muddy sand with beds of sandy limestone (biomicrudite) near the top of the formation. Sohl and Owens (1991) interpreted the Peedee Formation as having been deposited on the shelf and reflecting at least two cycles of sedimentation.

Most of the Peedee Formation is late Maastrichtian in age (Sohl and Owens, 1991; Edwards et al., 1999). Sohl and Owens (1991) divided the unit into three molluscan zones, the highest of which is the Haustator bilira Assemblage Zone, which, according to them, contains Sphenodiscus. This zone forms a band paralleling the Carolina coast and includes the fossil sites yielding the ammonites we describe.

The ammonites were collected from two sites in Brunswick County, North Carolina

Fig. 6. Dinoflagellates from the Severn Formation, Maryland. A, B, J-L, AMNH loc. 3260 (R6370), Brightseat, Prince Georges County; C, F, I, AMNH loc. 3252 (R6235), Lloyd Creek, Kent County; D, E, G, H, U.S.G.S. Paleobot. loc. R6374, Round Bay, Anne Arundel County. A, B. Deflandrea galatea (Lejeune-Carpentier, 1942) Lentin \& Williams, 1973. C. Thalassiphora pelagica (Eisenack, 1954) Eisenack \& Gocht, 1960. D, E. Palynodinium grallator Gocht, 1970. F. Palaeoperidinium sp. G, H. Disphaerogena carposphaeropsis Wetzel, 1933 (= Cyclapophysis monmouthensis). I. Circulodinium distinctum (Deflandre \& Cookson, 1955) Jansonius, 1986 species complex. J-L. Kleithriasphaeridium truncatum (Benson, 1976) Stover \& Evitt, 1978. 


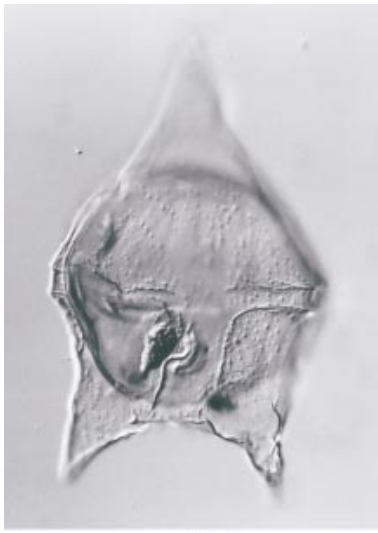

A

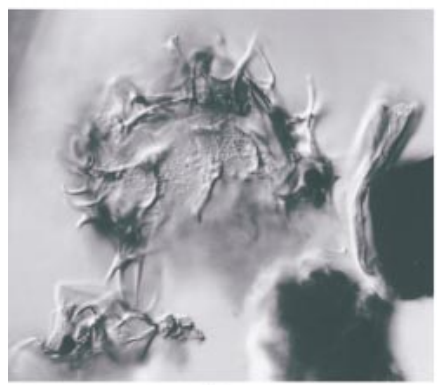

D
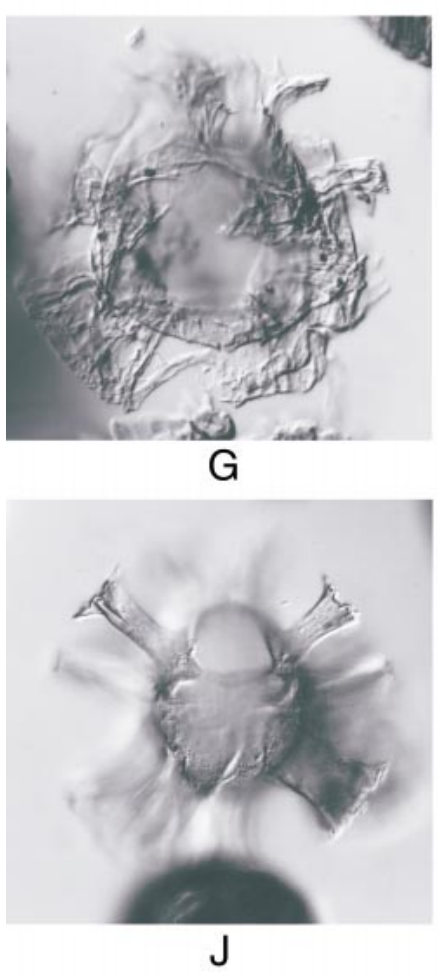

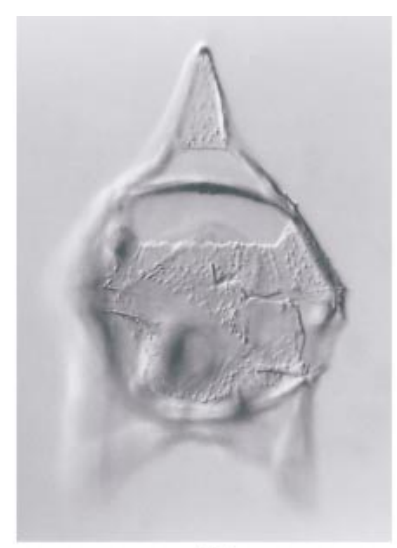

B
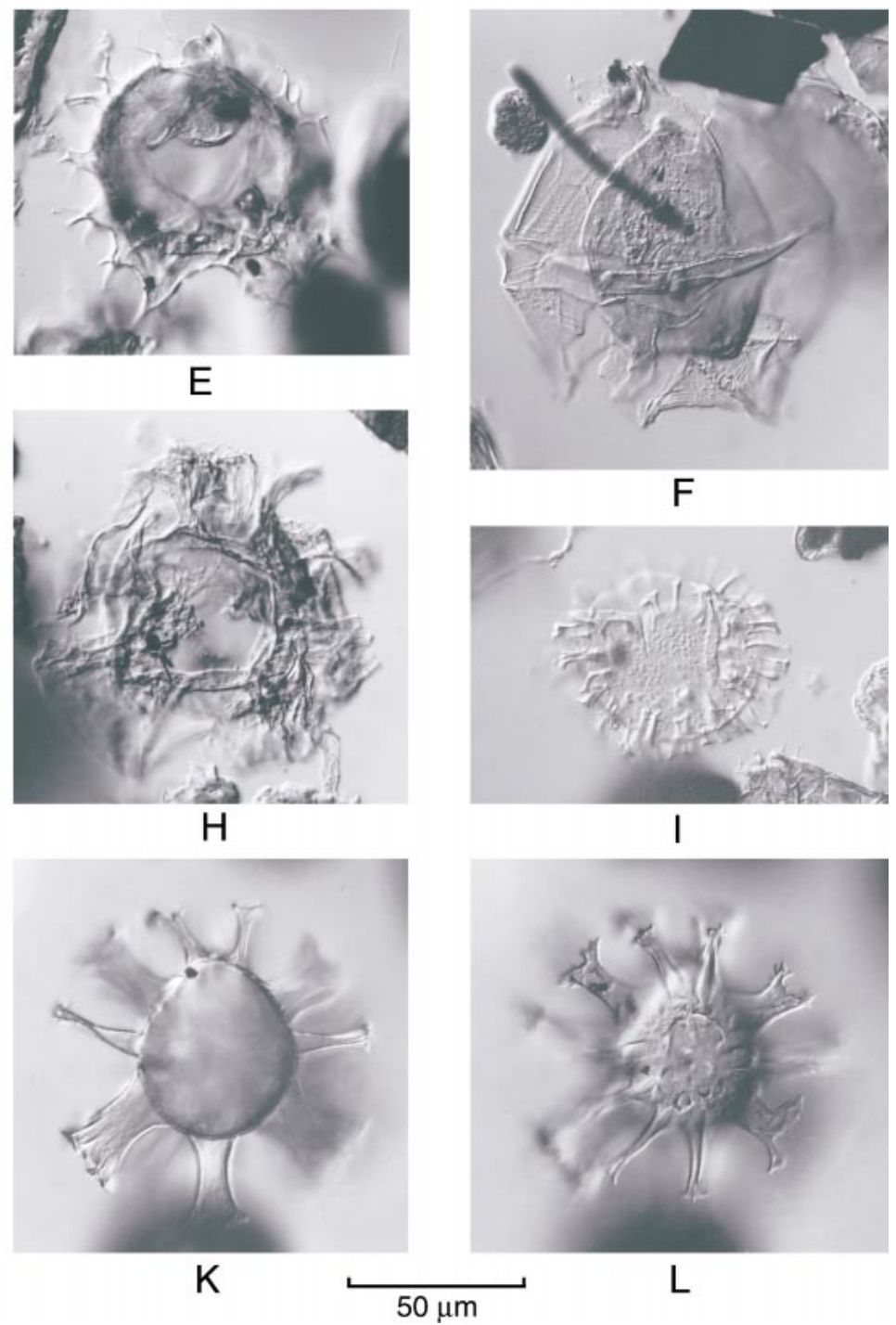
(fig. 1). Don Clements (Rocky Point, NC) collected at the Todd Marl Pit and supplied most of the information about both sites. The Todd Marl Pit produces crushed shell marl from the Plio-Pleistocene Waccamaw Formation, which unconformably overlies the Peedee Formation at this site. The pit exposes approximately $1.5 \mathrm{~m}$ of the Peedee Formation below the Waccamaw Formation. Occasionally, during mining operations, the entire portion of the Waccamaw Formation was removed, revealing the indurated, eroded upper surface of the Peedee Formation. The Peedee Formation consists of greenish, muddy, very fine to fine sand with indurated nodules randomly distributed throughout the section. These nodules contain masses of Exogyra, many of which are in life position. The associated fauna includes species of Eutrephoceras, Pycnodonte, Agerostrea, Cucullaea, and Anomia.

The second site, collected by Ned Gilmore (ANSP), is the John D. Long County Park. It is several kilometers from the well-known Hilton Park locality on the bluffs of the northeast Cape Fear River, Wilmington, New Hanover County, described by Stephenson (1923) and Sohl and Koch (1984), and reported to have Sphenodiscus. The County Park features a large square cut (approximately $80 \mathrm{~m}$ wide at its widest point) excavated into the banks of the Brunswick River. (This and adjacent cuts were made during World War II to house liberty ships that were constructed in nearby Wilmington.) The cut exposes at maximum low tide approximately $2 \mathrm{~m}$ of the Peedee Formation below the Waccamaw Formation. The Peedee Formation consists of muds and sands with two indu- rated ledges, one at the top of the formation and one at approximately $1 \mathrm{~m}$ above maximum low tide. The ammonite we describe probably comes from the lower indurated ledge.

The ammonites are all internal molds without any original shell. We identified one phragmocone of Sphenodiscus lobatus and five specimens of Discoscaphites gulosus, one of which is nearly complete but very worn. Based on the presence of D. gulosus, these ammonites probably represent the $D$. conradi Zone.

A sample of part of the phragmocone of Sphenodiscus lobatus (AMNH 48554) was analyzed for nannofossils by Jean M. SelfTrail (U.S. Geological Survey, Reston, VA). Nannofossils are abundant with moderate to good preservation. There is occasional overgrowth of the nannofossils but not enough to obscure identification. The taxa are listed in table 2 and notably include Lithraphidites quadratus Bramlette and Martini, 1964.

\section{BIOSTRATIGRAPHY}

Integrating the ammonite, dinoflagellate, and nannofossil data from these various sites helps refine the age of the Severn and Peedee Formations and clarify the ammonite zonation of the upper Maastrichtian. Our aim is to correlate the ammonite zones in this area with the established calcareous nannofossil zonation.

\section{AMmONite Biostratigraphy}

The upper Maastrichtian on the Gulf and Atlantic Coastal Plain has been divided into two ammonite zones. Cobban and Kennedy

Fig. 7. Dinoflagellates from the Severn Formation, Maryland. D-H, J, K, M, Q, S, AMNH loc. 3260 (R6370), Brightseat, Prince Georges County; N-P, AMNH loc. 3252 (R6235), Lloyd Creek, Kent County; A-C, I, L, R, U.S.G.S. Paleobot. loc. R6374, Round Bay, Anne Arundel County. A-C. Glaphyrocysta expansa (Corradini, 1972) Roncaglia \& Corradini, 1997 (? = G. perforata sensu Schiøler et al., 1997). D. Cordosphaeridium fibrospinosum Davey \& Williams, 1966. E. Operculodinium/Fibrocysta complex. F, G. Isabelidinium aff. I. cooksoniae (Alberti, 1959) Lentin \& Williams, 1977. H. Hafniasphaera fluens Hansen, 1977. I, K. Cribroperidinium spp. misc. J. Conneximura fimbriata May, 1980. L. Tanyosphaeridium xanthiopyxides (Wetzel, 1933) Stover \& Evitt, 1978. M. Piercites pentagonum (May, 1980) Habib \& Drugg, 1987. N. Spinidinium ?clavus Harland, 1973. O. Palaeocystodinium australinum (Cookson, 1965) Lentin \& Williams, 1976. P. ?Andalusiella rhombohedra of Edwards et al. (1984). Q. Areoligera/Glaphyrocysta complex. R. Miscellaneous small peridinicean. S. Cyclopsiella ?sp. of Edwards et al. (1984). 


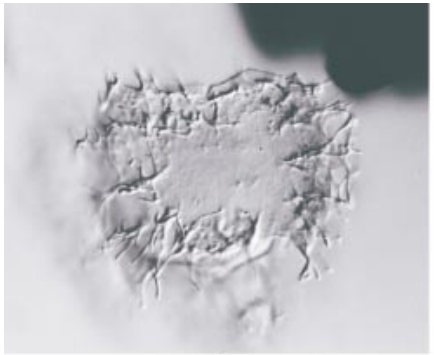

A

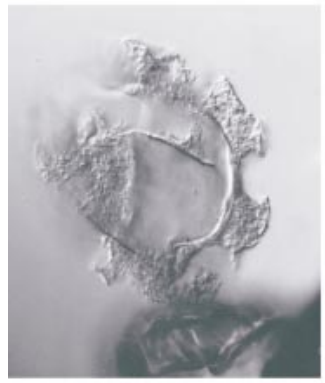

D

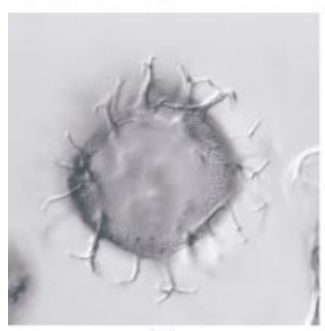

$\mathrm{H}$
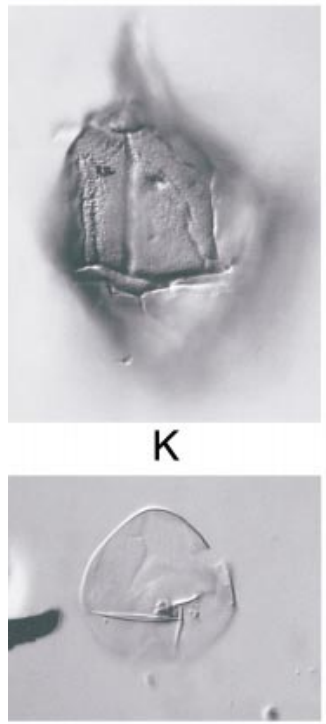

$\mathrm{P}$

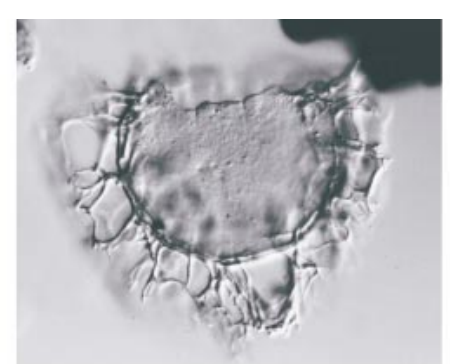

B

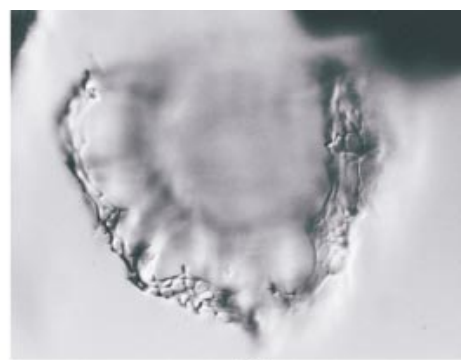

C

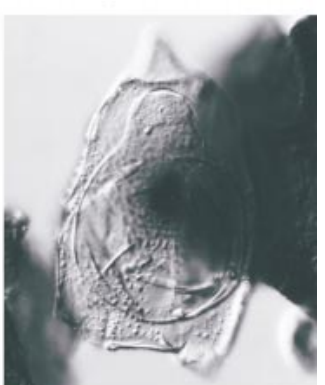

G
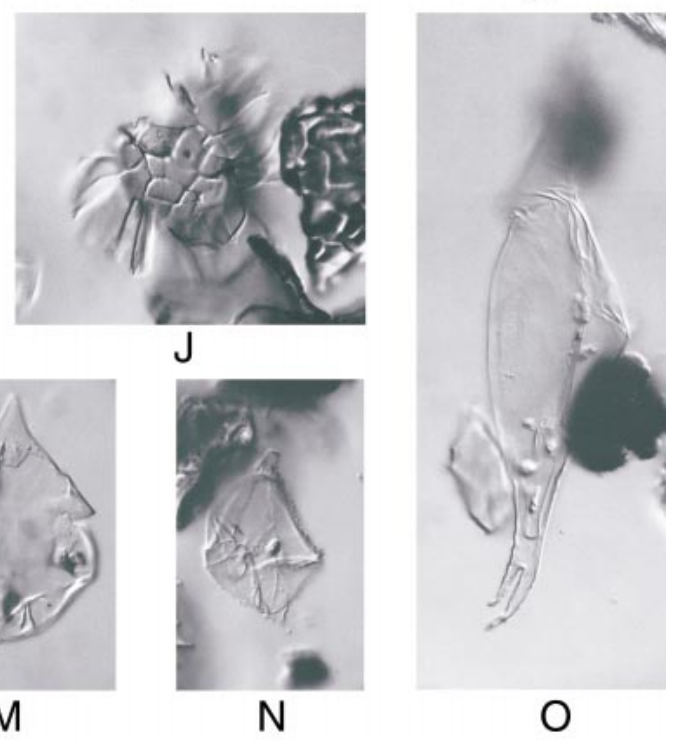

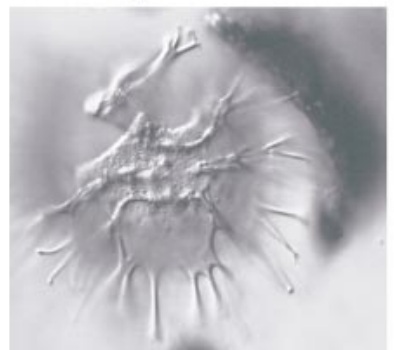

Q

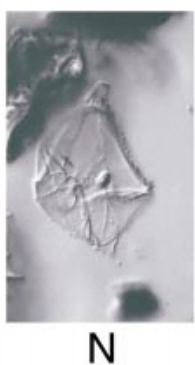

M

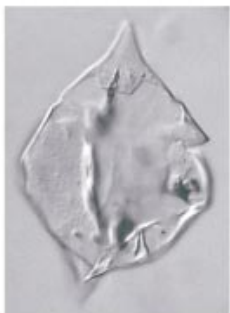

M

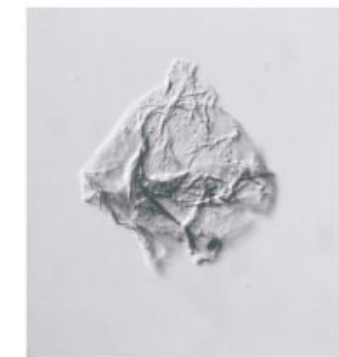

R

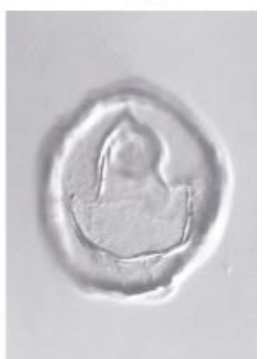

S 
TABLE 2

Nannofossil Taxa from the Peedee Formation, Todd Marl Pit, Brunswick County, North Carolina (J. Self-Trail, personal commun., 2004)

Ahmuellerella octoradiata (Górka, 1957) Reinhardt, 1966 Ahmuellerella regularis (Górka, 1957) Reinhardt and Górka, 1967

Angulofenestrellithus snyderi Bukry, 1969

Arkhangelskiella cymbiformis Vekshina, 1959

Chiastozygus antiquus (Perch-Nielsen, 1973) Burnett, 1998b

Chiastozygus synquadriperforatus Bukry, 1969

Cribrosphaerella ehrenbergii (Arkhangelsky, 1912)

Deflandre in Piveteau, 1952

Cylindralithus? nieliae Burnett, 1998b

Discorhabdus ignotus (Górka, 1957) Perch-Nielsen, 1968

Eiffellithus gorkae Reinhardt, 1965

Eiffellithus turriseiffelii (Deflandre in Deflandre and Fert, 1954) Reinhardt, 1965

Gartnerago obliquum (Stradner, 1963) Nöel, 1970

Helicolithus trabeculatus (Górka, 1957) Verbeek, 1977

Lithraphidites carniolensis Deflandre, 1963

Lithraphidites quadratus Bramlette and Martini, 1964

Microrhabdulus undosus Perch-Nielsen, 1973

Micula decussata Vekshina, 1959

Prediscosphaera cretacea (Arkhangelsky, 1912) Gartner, 1968

Prediscosphaera stoveri (Perch-Nielsen, 1968) Shafik and Stradner, 1971

Stradneria crenulata (Bramlette and Martini, 1964) Nöel, 1970

Watznaueria barnesae (Black and Barnes, 1959) PerchNielsen, 1968

Zeugrhabdotus erectus (Deflandre in Deflandre and Fert, 1954) Reinhardt, 1965

Zeugrhabdotus spiralis (Bramlette and Martini, 1964)

Burnett, 1998b

(1995) established the Discoscaphites conradi Zone and the $D$. iris Zone. They placed the $D$. conradi Zone above the D. iris Zone but did not regard this placement as definitive.

We argue for a slightly different zonal scheme based on the succession of ammonites and associated dinoflagellates in the Severn Formation and correlative units on the Gulf and Atlantic Coastal Plain. We recognize three ammonite zones (fig. 8). The lowest is the $D$. conradi Zone, the next higher is the D. minardi Zone, and the highest is the D. iris Zone.

The D. conradi Zone was established by Cobban and Kennedy (1995) for ammonite occurrences in parts of the Corsicana For- mation in northeast Texas, the Prairie Bluff Chalk in Mississippi and Alabama, and the Severn Formation in Maryland. The ammonites consist of Sphenodiscus lobatus, $S$. pleurisepta, Discoscaphites conradi, Discoscaphites gulosus, Jeletzkytes nebrascensis, Glyptoxoceras rugatum, Baculites vertebralis, Eubaculites carinatus, and E. latecarinatus.

The D. conradi Zone is an assemblage zone and not all of its constituent species are present throughout its stratigraphic and geographic range. For example, Jeletzkytes nebrascensis is absent in the Prairie Bluff Chalk but is present in the Severn Formation. The boundaries of the $D$. conradi Zone were not specified, but by implication, the lower boundary is the lowest occurrence of $D$. conradi. The upper boundary is the lowest occurrence of Discoscaphites minardi, n.sp. of the overlying $D$. minardi Zone. On the basis of the associated dinoflagellates, the $D$. conradi Zone is the lowest of the three ammonite zones described (see below).

The $D$. conradi Zone is represented in Maryland by the ammonite fauna of the Severn Formation at Oxon Hill, Randolph Village, Brightseat, Landover, and Largo, Prince Georges County, Maryland, on the western shore of Chesapeake Bay (Kennedy et al., 1997). This zone has not been recognized in other parts of Maryland although age-equivalent strata are present (see below).

The $D$. conradi Zone occurs in the Peedee Formation in Brunswick County, North Carolina, although the name bearer of this zone has not yet been collected from this site. The beds contain Sphenodiscus lobatus and Discoscaphites gulosus and overlap with part or all of the Haustator bilira Assemblage Zone (Sohl and Owens, 1991).

The D. conradi Zone is not well expressed in New Jersey, although age-equivalent strata are present as indicated by associated dinoflagellates. Sphenodiscus lobatus, Baculites vertebralis, and a single specimen of Jeletzkytes nebrascensis have been recovered in association with dinoflagellates in the upper part of the Navesink Formation and the lower part of the New Egypt Formation in the Crosswicks Creek Drainage in southern Monmouth County. Sphenodiscus lobatus and associated dinoflagellates also occur in 


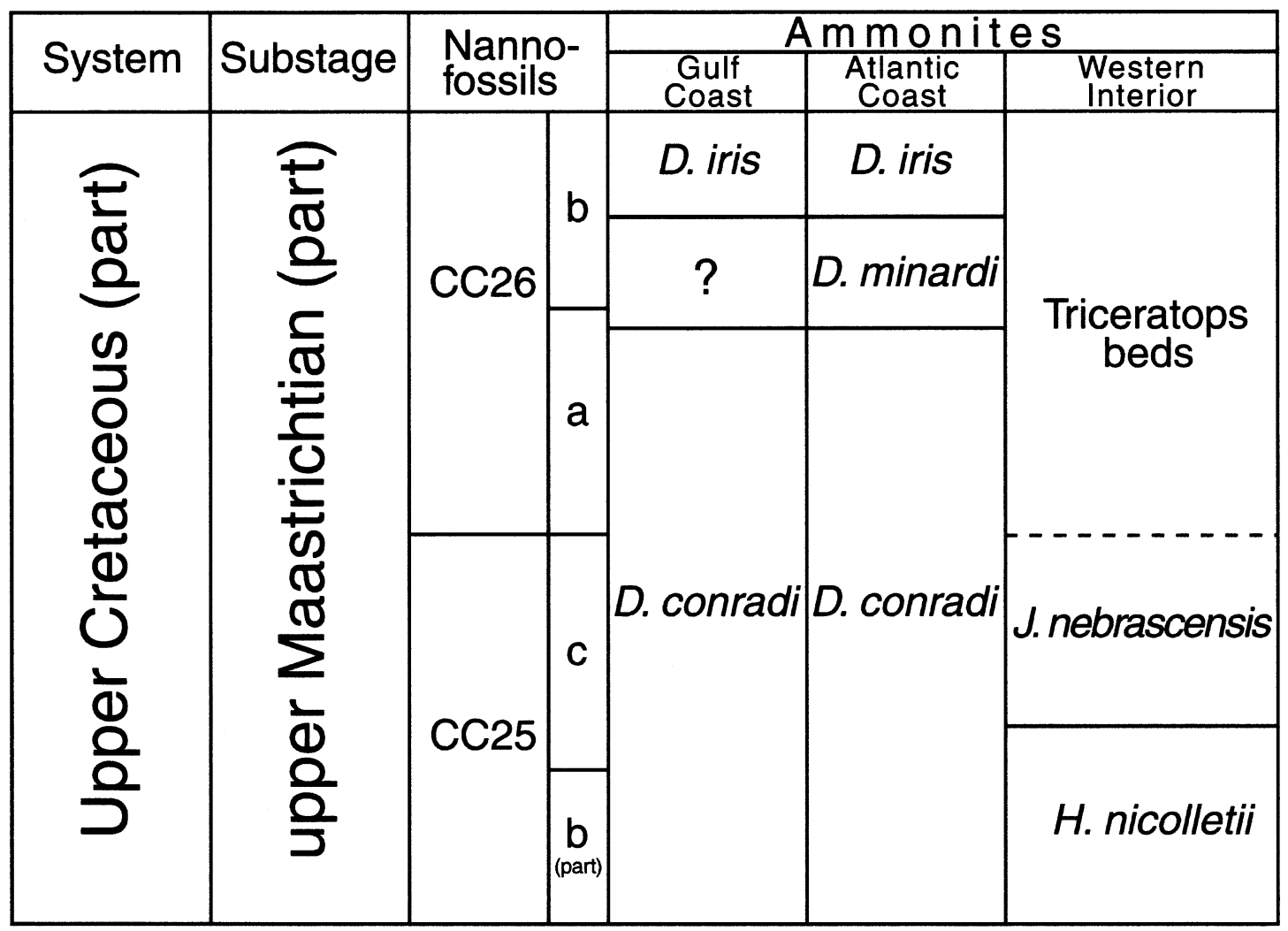

Fig. 8. Proposed ammonite zonation of the upper Maastrichtian on the Gulf and Atlantic Coastal Plain and the corresponding zones in the U.S. Western Interior. The base of each zone is defined by the lowest occurrence of the index ammonite. The ammonite zones are correlated with the established calcareous nannofossil zonation based on the biostratigraphic distribution of the dinoflagellates and nannofossils associated with the ammonites in Maryland and North Carolina. The D. minardi Zone has not yet been recognized in the Gulf Coastal Plain. Correlation with the ammonite zones in the Western Interior is based on the presence of Discoscaphites conradi and Isabelidinium cooksoniae.

the middle of the Tinton Formation in northeastern Monmouth County, but no scaphites have been recovered from this site.

The D. conradi Zone on the Gulf and Atlantic Coastal Plain corresponds, in part, to the combined zones of Hoploscaphites nicolletii and Jeletzkytes nebrascensis in the Western Interior (fig. 8). Discoscaphites conradi is present in the $H$. nicolletii Zone in the Fox Hills Formation, South Dakota, where it is associated with $H$. nicolletii, Discoscaphites gulosus, Jeletzkytes spedeni Landman and Waage, 1993, Trachybaculites columna (Morton, 1834), and Sphenodiscus lobatus. Discoscaphites conradi is also present, although not common, in the J. nebrascensis Zone in the Fox Hills Formation, South Da- kota (Landman and Waage, 1993), where it is associated with J. nebrascensis, Hoploscaphites comprimus (Owen, 1852), D. gulosus, Discoscaphites rossi Landman and Waage, 1993, S. lobatus, and rare specimens of T. columna and Baculites larsoni Cobban and Kennedy, 1992. The underlying Hoploscaphites birkelundae Zone lacks any species of Discoscaphites and is older than the $D$. conradi Zone (Landman and Cobban, 2003).

Landman and Waage (1993) assigned the $H$. nicolletii and J. nebrascensis Zones to the lower part of the upper Maastrichtian on the basis of the biostratigraphic distribution of inoceramid bivalves and Discoscaphites in comparison with the distribution of these fossils in the Gulf Coastal Plain and northwest 
Europe. Palamarczuk et al. (2003) reached a similar conclusion based on an analysis of dinoflagellates from approximately the same stratigraphic interval in southwestern South Dakota (see below).

Landman and Waage (1993: 212, 230) noted minor morphological differences between populations of $D$. conradi and D. gulosus from the Corsicana Formation, the Prairie Bluff Chalk, and the Severn Formation versus those from the Fox Hills Formation. Specimens from the Gulf and Atlantic Coastal Plain commonly include more highly ornamented forms with a midventral row of tubercles compared to those in the Western Interior (e.g., contrast specimens of D. gulosus from the Severn Formation [Kennedy et al., 1997: figs. 20K, O, 21D, E] with those from the Fox Hills Formation [Landman and Waage, 1993: figs. 167-172]). These differences may reflect ecophenotypic variation related to differences in temperature, depth, substrate, and predation intensity. However, it is equally possible that the beds in these two areas are not exactly equivalent in age. Because specimens of $D$. gulosus with a midventral row of tubercles are present, although rare, in the J. nebrascensis Zone, whereas they are absent altogether in the underlying $H$. nicolletii Zone, Landman and Waage (1993) speculated that the more highly ornamented form of $D$. gulosus is younger, thus implying that the populations of D. gulosus and D. conradi on the Gulf and Atlantic Coastal Plain, which include a greater proportion of highly ornamented forms, are slightly younger than those in the Western Interior.

The Gulf and Atlantic Coastal Plain also share few ammonite species in common with the Western Interior, further suggesting, by negative evidence, that the beds are not exactly equivalent in age in these two areas. Curiously, Jeletzkytes nebrascensis is absent in the D. conradi Zone in Mississippi and Alabama but is present in this zone in Maryland and New Jersey.

The ammonite occurrences at Lloyd Creek define a new zone called the $D$. minardi Zone after the most abundant species. The $D$. minardi Zone is an assemblage zone dominated by $D$. minardi, n.sp., Baculites vertebralis, Sphenodiscus pleurisepta, and Sphenodiscus sp., with rare specimens of Eubaculites latecarinatus and Discoscaphites iris. The lower boundary of this zone is defined by the lowest occurrence of $D$. minardi, n.sp., and the upper boundary is defined by the lowest occurrence of abundant $D$. iris of the overlying $D$. iris Zone. The position of the $D$. minardi Zone above the D. conradi Zone and below the $D$. iris Zone is based on stratigraphic superposition and associated dinoflagellates (see below).

The D. minardi Zone has not been recognized elsewhere in Maryland although age-equivalent strata are present at Round Bay (see below). The D. minardi Zone is present at AMNH loc. 3346 near Eatontown, northeastern Monmouth County, New Jersey, at the top of the New Egypt Formation approximately $1.5-2 \mathrm{~m}$ below the base of the overlying D. iris Zone. The D. minardi Zone may also occur in the upper part of the Corsicana Formation, Texas, where specimens similar to D. minardi, n.sp. have been reported (Kennedy and Cobban, 1993), but the stratigraphic position of these ammonites is not well enough constrained to adequately demonstrate this at present.

The highest ammonite zone is the Discoscaphites iris Zone. Cobban and Kennedy (1995) defined the D. iris Zone based on occurrences of this species and associated ammonites on the Gulf Coastal Plain in the upper part of the Owl Creek Formation (and as reworked fossils in the basal Clayton Formation) in Mississippi, Tennessee, and Missouri (Stephenson, 1955; Sohl, 1960, 1964; Kennedy and Cobban, 2000). The fauna consists of D. iris, D. sphaeroidalis Kennedy and Cobban, 2000, D. cf. D. conradi, Baculites cf. B. claviformis Stephenson, 1941, B. cf. B. undatus Stephenson, 1941, and Sphenodiscus pleurisepta. Elsewhere on the Gulf Coast, this zone occurs in the upper part of the Corsicana Formation (and as reworked fossils in the basal Kincaid Formation) on the Brazos River, Falls County, Texas (Kennedy et al., 2001), where it contains Pachydiscus (Pachydiscus) jacquoti jacquoti Seunes, 1890, D. sphaeroidalis, D. cf. D. gulosus, Eubaculites carinatus, and Glyptoxoceras cf. G. rugatum.

Cobban and Kennedy (1995) defined this zone as an assemblage zone, and not all of 
its constituent species are present throughout the stratigraphic and geographic range of the zone. They did not specify the boundaries of the zone, but, by implication, the lower boundary is the lowest occurrence of abundant $D$. iris and the upper boundary is the highest occurrence of $D$. iris, coinciding with the Cretaceous/Tertiary boundary.

The D. iris Zone is present at Round Bay, Anne Arundel County, where it consists of Discoscaphites iris, D. cf. D. iris, D. cf. D. minardi, n.sp., Eubaculites carinatus, and $E$. cf. E. carinatus. The D. iris Zone is also present in New Jersey (Landman et al., in prep. a) where it contains Pachydiscus (Neodesmoceras) mokotibensis Collignon, 1952, D. iris, D. gulosus, E. carinatus, E. latecarinatus, Sphenodiscus pleurisepta, and S. lobatus. It occurs in the top of the New Egypt Formation (and as reworked fossils at the base of the Hornerstown Formation) near Eatontown, northeastern Monmouth County (Landman et al., in prep. a), near New Egypt, southwestern Monmouth County (Landman et al., in prep. c), and near Sewell, Gloucester County (Kennedy and Cobban, 1996), and in the top of the Tinton Formation (and as reworked fossils at the base of the Hornerstown Formation), near Freehold, central Monmouth County (Landman et al., in prep. b).

The D. iris Zone occurs at and just below the Cretaceous/Tertiary boundary and is thus the youngest ammonite zone in North America. Stratigraphic superposition and the associated species of dinoflagellates (see below) indicate that this zone occurs above the $D$. minardi Zone. The D. iris Zone is widespread and extends from Texas, Mississippi, Tennessee, and Missouri on the Gulf Coastal Plain to Maryland and New Jersey on the Atlantic Coastal Plain.

\section{DinOFlagellate Biostratigraphy}

All of the samples from Maryland contain dinoflagellates, but calcareous nannofossils are absent. To evaluate the dinoflagellate occurrences in these samples, we relied on the biostratigraphic zonation established by Firth (1987) and Edwards et al. (1999) on the Atlantic Coastal Plain. The Santee Coastal Reserve (SCR) core from Charleston County,
South Carolina, includes the Maastrichtian Peedee Formation and contains nannofossils, foraminifera, and dinoflagellates (Edwards et al., 1999). The core is also calibrated with strontium isotope- and magnetostratigraphy. Because this core is located on the Atlantic Coastal Plain, it provides an excellent means of correlating the dinoflagellates in the Maryland samples with the standard calcareous nannofossil zonation. Furthermore, by regressing the age-calibrated paleomagnetic data and the ranges of calcareous nannofossils against depth in the SCR core, Edwards et al. (1999, fig. 11) calculated numerical ages for key dinoflagellate datums.

The occurrences of key dinoflagellate species in the SCR core are listed below (Edwards et al., 1999, fig. 5):

Lowest occurrence of Palynodinium grallator (370.3 ft in SCR core)

Lowest occurrence of Disphaerogena carposphaeropsis (389.3 $\mathrm{ft}$ in SCR core)

Lowest occurrence of Thalassiphora pelagica (390.8 ft in SCR core)

Highest occurrence of Isabelidinium cooksoniae (436.4 ft in SCR core)

Lowest occurrence of Deflandrea galatea (436.4 $\mathrm{ft}$ in SCR core)

Highest occurrence of Alterbidinium acutulum (474.2 ft in SCR core)

As noted by Edwards et al. (1999), there are several caveats to consider when using the SCR core for precise correlations. First, although the base of the Peedee Formation in the SCR core lies in Subzone CC25b, the exact position of the base within this subzone is unknown. Second, calcareous nannofossil Subzones CC25b, CC26a, and CC26b are recognized in the SCR core, but Subzone $\mathrm{CC} 25 \mathrm{c}$ is not. Micula murus, which elsewhere defines the base of Subzone CC25c, first appears in the SCR core within Subzone CC26a, indicating a delayed occurrence. However, the interpretation of the paleomagnetic data in the core by Edwards et al. (1999) suggests that the chronozone of Subzone CC25c is present. Third, Subzone CC26a may be truncated in the SCR core because Lithraphidites kennethii, which occurs elsewhere midway in Subzone CC26a, occurs near the base of this subzone in the SCR core; alternatively, L. kennethii may have a longer range than previously reported. 


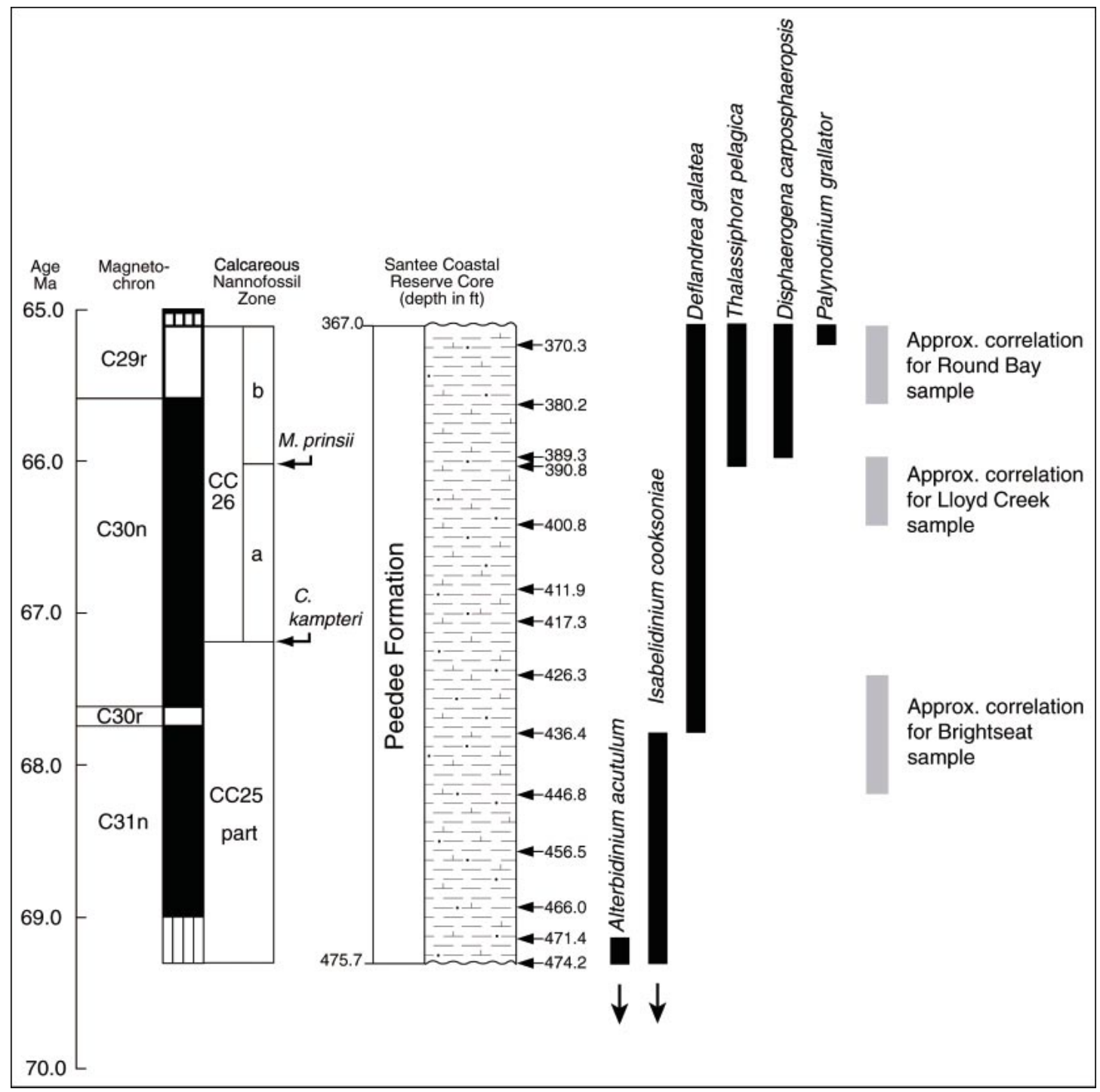

Fig. 9. Approximate correlation of the samples from Maryland with the Santee Coastal Reserve (SCR) core (Edwards et al., 1999). The horizontal arrows indicate sample locations in the SCR core. Because calcareous nannofossil Subzone CC25c is missing in the SCR core, Zone CC25 is shown as undifferentiated. The time scale is based on Berggren et al. (1995) as interpreted for the SCR core by Edwards et al. (1999).

Finally, it is difficult to determine if Subzone $\mathrm{CC} 26 \mathrm{~b}$ is complete, but based on paleomagnetic and lithologic data, there is probably a small hiatus (ca. 100,000 years) at the top of this subzone. The absence of Plummerita hantkeninoides from the top of the Cretaceous also suggests that the uppermost Maastrictian is absent in the SCR core.

The dinoflagellates at AMNH loc. 3260
(R6374) near Brightseat, Prince Georges County, Maryland, include Deflandrea galatea and Isabelidinium aff. I. cooksoniae (fig. 9). By comparison with the reported occurrences of these species in the Santee Coastal Reserve core, this sample represents the lower part of the upper Maastrichtian. It is approximately correlative with material from $436.4 \mathrm{ft}$ in the SCR core, which coincides 
with calcareous nannofossil Subzone CC25b (Edwards et al., 1999). However, the precise position within this subzone is unknown. The base of the Peedee Formation in the SCR core contains Alterbidinium acutulum, which is absent in the Brightseat sample, thus implying, by negative evidence, that this sample is slightly younger than the base of the Peedee Formation in the SCR core. By comparison with the SCR core, the Brightseat sample is 68.2-67.4 MaBP.

Benson (1976), as quoted in Firth (1987: text-fig. 7), reported Isabelidinium cooksoniae in his Zones $\mathrm{A}$ and $\mathrm{B}$, comprising the lower $4.5 \mathrm{~m}$ of the Severn Formation at Round Bay, Anne Arundel County. The highest occurrence of this species is in his Zone B. Palamarczuk et al. (2003) also reported I. cooksoniae as well as Cordosphaeridium fibrospinosum from their sample from the Fox Hills Formation in South Dakota.

The dinoflagellates at AMNH loc. 3252 (R6235), Lloyd Creek, Kent County, include Deflandrea galatea and Thalassiphora pelagica (fig. 9). However, Disphaerogena carposphaeropsis Wetzel, 1933 and Palynodinium grallator are absent, suggesting that this sample is upper, but not uppermost, Maastrichtian. It is approximately correlative with material from $390.8 \mathrm{ft}$ in the SCR core, which lies within the Nephrolithus frequens calcareous nannofossil Zone encompassing the upper part of Subzone CC26a and the lower part of Subzone CC26b (Edwards et al., 1999), according to the calcareous nannofossil zonation of Perch-Nielsen (1985). By comparison with the SCR core, the Lloyd Creek sample is 66.4-66.0 MaBP.

This interval correlates with the lower part of Zone C of Benson (1976) in the middle of the Severn Formation at Round Bay. It is above the highest occurrence of Isabelidinium cooksoniae at the top of his Zone B and below the lowest occurrence of Disphaerogena carposphaeropsis $(=$ Cyclapophysis monmouthensis) near the middle of his Zone C. The Lloyd Creek sample also contains the Circalodinium distinctum (Deflandre \& Cookson, 1955) Jansonius, 1986 species complex equivalent to Benson's Cyclonephelium distinctum, which ranges from the middle of his Zone B to the lower part of his Zone C. However, Thalassiphora pelagica, which is present in the Lloyd Creek sample, was not reported by Benson (1976) at Round Bay, which is surprising given how distinctive and well known this species is.

The dinoflagellates at Round Bay, Anne Arundel County (R6374), include Palynodinium grallator and questionable specimens of Thalassiphora pelagica (fig. 9). These species represent the uppermost Maastrichtian Palynodinium grallator Zone, probably the Tpe (T. pelagica) Subzone of Schiøler and Wilson (1993) correlative with the upper part of calcareous nannofossil Subzone CC26b (65.6-65.0 Ma). Benson (personal commun. in Firth: 1987: text-fig. 7) reported $P$. grallator in the upper part of his Zone C in the upper $2 \mathrm{~m}$ of the Severn Formation at Round Bay, presumably from approximately the same interval that we sampled.

\section{NANNOFOSSIL BIOSTRATIGRAPHY}

The nannofossils from the Peedee Formation from Brunswick County, North Carolina, include Lithraphidites quadratus, indicating nannofossil Subzone CC25b (J.M. Self-Trail, personal commun., 2004) (table 2 ). Furthermore, no species indicative of the overlying Zone CC26 are present (e.g., Ceratolithoides kamptneri or Micula prinsii).

\section{BIOSTRATIGRAPHIC SYNTHESIS}

The dinoflagellates and nannofossils associated with the ammonites permit an approximate correlation of the ammonite zones with the standard calcareous nannofossil zonation. The $D$. minardi Zone and the $D$. iris Zone are each represented by a single dinoflagellate sample from Maryland, while the D. conradi Zone is represented by a dinoflagellate sample from Maryland and a nannofossil sample from North Carolina, both of which yielded the same age. We regard the sample from each ammonite zone as marking the base of that particular zone.

The biostratigraphic distribution of dinoflagellates and nannofossils supports the proposed ammonite zonation indicating, in ascending stratigraphic order, the Discoscaphites conradi Zone, the D. minardi Zone, and the $D$. iris Zone (fig. 8). The base of the $D$. conradi Zone approximately correlates with Subzone CC25b although its precise position 
is indeterminate. The base of the $D$. minardi Zone approximately correlates with the Subzone CC26a/b boundary but may range from the very uppermost part of Subzone CC26a to the lowermost part of Subzone CC26b. The base of the D. iris Zone approximately correlates with the upper part of calcareous nannofossil Subzone CC26b.

The inferred ages of the $D$. conradi Zone in Maryland and North Carolina and the $D$. iris Zone in Maryland are compatible with the published ages of the formations in which these zones occur elsewhere on the Gulf and Atlantic Coastal Plain. The D. conradi Zone occurs in parts of the Prairie Bluff Chalk in Alabama and Mississippi, as well as in the Corsicana Formation in northeast Texas. The D. iris Zone occurs in the Owl Creek Formation in Mississippi, Tennessee, and Missouri, in the upper part of the Coriscana Formation in Falls County, Texas, and in the New Egypt Formation in New Jersey. All of these formations span the upper Maastrichtian and include the estimated ranges of both ammonite zones (for the age of the Corsicana Formation, see Kennedy and Cobban [1993] and Kennedy et al. [2001]; for the Prairie Bluff Chalk, see Smith and Mancini [1982] and Olsson et al. [1996]; for the Owl Creek Formation, see Stephenson [1955], Russell [1975], Smith and Mancini [1982], Kennedy and Cobban [2000], and Kennedy et al. [2001]; and for the New Egypt Formation, see Landman et al. [in prep. a, c]).

\section{Age and Correlation of the Severn FORMATION}

Our conclusions about the age and correlation of the Severn Formation are consistent with previously published interpretations of the age of this unit and indicate that the ammonite-bearing beds were deposited during the late Maastrichtian (fig. 5). Furthermore, based on age and stratigraphic relationships, erosion must have removed some of the formation in the southwestern part of its distribution.

The upper part of the Severn Formation in Prince Georges County represents the lower part of the upper Maastrichtian, corresponding to calcareous nannofossil Subzone CC25b. This falls within the range inferred by Kennedy et al. (1997), Sohl and Koch (1984), Smith (personal commun., 1976, in Brouwers and Hazel, 1978), and May (personal commun., 1976, in Brouwers and Hazel, 1978) (fig. 5). This assignment is also consistent with that of Brouwers and Hazel (1978), even though their conclusions were based on samples from the entire thickness of the formation in this area. Beds of this age occur in the lower part of the Severn Formation at Round Bay, based on the dinoflagellate biostratigraphy of Benson (1976) and Firth (1987).

The lower part of the upper one-third of the Severn Formation at Lloyd Creek represents the middle part of the upper Maastrichtian, corresponding to the top of calcareous nannofossil Subzone CC26a and the bottom of Subzone CC26b (fig. 5). This falls within the range inferred by Minard (1980) and Sohl and Koch (1984) for the same stratigraphic interval, as well as that inferred by Olsson (1992), Brennen (1992), and Gohn (1992), even though their conclusions were based on samples from the top and bottom of the formation at another, nearby locality. Age-equivalent strata occur in the lower part of the upper one-third of the Severn Formation at Round Bay, based on the dinoflagellate biostratigraphy of Benson (1976) and Firth (1987).

The upper part of the Severn Formation at Round Bay represents the upper part of calcareous nannofossil Subzone CC26b. This interpretation is consistent with that of Benson (1976) and Firth (1987) and falls within the range of Sohl and Koch (1984), all of whose samples are from the same stratigraphic interval. It differs from that of May (1980) whose conclusions were based on samples from the same and nearby sites (fig. 5).

Our results suggest that the upper part of the Severn Formation encompassing at least the upper two ammonite zones is missing from Prince Georges County. This interval must have been removed by erosion at the end of the Cretaceous or beginning of the Paleocene. This interpretation is consistent with isopach maps showing a thinning and rapid pinching out of the Severn Formation without any change in lithofacies in the western part of Prince Georges County (Glaser, 
1968), implying that the Severn Formation originally covered a much broader area and was subsequently removed by erosion.

\section{Ammonite Diversity AND Biogeography}

The presence of three ammonite zones in parts of the Gulf and Atlantic Coastal Plain indicates a succession of ammonite communities that lived along the late Maastrichtian coastline. However, there is no indication that these communities were persistent over time. In contrast, the stratigraphic record suggests that these communities were intermittent, although the vagaries of taphonomy always complicate any interpretation.

To assess the change in ammonite diversity over time, we counted up the number of species in each zone. We included all the species in a zone even if they did not occur everywhere in that zone (e.g., we included Jeletzkytes nebrascensis in the D. conradi Zone even though it does not occur in the Prairie Bluff Chalk). We did not include questionable species referred to as "cf." or "sp." The number of ammonite species over time does not vary significantly. There are nine species in the $D$. conradi Zone, five in the $D$. minardi Zone, and eight in the $D$. iris Zone, implying no monotonic decrease in diversity toward the close of the Cretaceous. The youngest zone, the $D$. iris Zone, is very fossiliferous, especially in Mississippi, Tennessee, Missouri, and New Jersey. Recently discovered exposures in the Manasquan Basin near Freehold, central Monmouth County, New Jersey, are especially rich in ammonites and other molluscs (Landman et al., in prep. b). These occurrences indicate a thriving community immediately prior to the extinction of the ammonites at the end of the Cretaceous.

The fauna in all three ammonite zones shows a similar biogeographic pattern involving a mix of endemic and cosmopolitan species. In the early part of the late Maastrichtian, Discoscaphites conradi, D. gulosus, Jeletzkytes nebrascensis, and Sphenodiscus lobatus were widely distributed in the Western Interior as well as in parts of the Gulf and Atlantic Coast. The two species of diplomoceratids, Baculites vertebralis and Glyptoxoceras rugatum, were absent in the
Western Interior but were present in the Gulf and Atlantic Coast, in addition to Europe, Asia, and Africa. After the disappearance of the Western Interior Seaway or at least a connection between it and the Gulf and Atlantic Coast in the middle late Maastrichtian, ammonite species were either endemic to the Gulf and Atlantic Coast or were cosmopolitan. During D. minardi Zone time, B. vertebralis, Eubaculites latecarinatus, and E. carinatus were cosmopolitan while during $D$. iris Zone time, E. latecarinatus, E. carinatus, Pachydiscus (Neodesmoceras) mokotibensis, and $P$. (P.) jacquoti jacquoti were cosmopolitan.

\section{Conventions}

The ammonites described in this paper are reposited in the Academy of Natural Sciences of Philadelphia (ANSP), the American Museum of Natural History (AMNH), the Monmouth Amateur Paleontologist's Society (MAPS), West Long Branch, New Jersey, and the U.S. National Museum (USNM). Dimensions of specimens are expressed in millimeters. Arrows on photographs indicate the base of the body chamber, where visible. All specimens were photographed in the conventional manner (with the aperture on top) except for scaphites and sphenodiscids, which are oriented with the aperture on the bottom, approximating their position in life. Suture terminology is that of Wedekind (1916), as reviewed by Kullmann and Wiedmann (1970). The term "rib index" as applied to baculites is the number of ribs in a distance equal to the whorl height at the midpoint of the interval over which the ribs were counted. The value of the rib index can be an integer or a fraction, although a fractional part of a rib does not make any sense from a practical point of view.

In discoscaphites with multiple rows of tubercles, we report the distance between tubercle rows at midshaft. The distance is also given, if possible, between outer ventrolateral tubercles on either side of the venter. These measurements involve several approximations: (1) the measurements are taken from the tips of the tubercles or, if the tubercles are elongate, from midway on the swellings; (2) the measurements do not take 
into account the curvature of the flanks (sometimes the tubercles occur on an inflated surface, sometimes on a flat surface); and (3) the measurements are taken to the nearest $0.25 \mathrm{~mm}$.

\section{SYSTEMATIC PALEONTOLOGY}

CLASS CEPHALOPODA

ORDER AMMONOIDEA VON ZITTEL, 1884

SUBORDER AMMONITINA HYATT, 1889

SUPERFAMILY ACANTHOCERATACEAE DE
GROSSOUVRE, 1894

FAMILY SPHENODISCIDAE HYATT, 1900

Genus Sphenodiscus Meek, 1871

Type Species: Ammonites lenticularis Owen, 1852: 579 (non Young and Bird, 1828: 269, fig. 5), by original designation, = Ammonites lobata Tuomey, 1856: 168.

\section{Sphenodiscus pleurisepta (Conrad, 1857)}

Figures 10A-J

Ammonites pleurisepta Conrad, 1857: 159, pl. 15, fig. 1.

Sphenodiscus lenticularis (Owen). Kellum, 1962: 68, pl. 4, figs. 3, 4; pl. 5, fig. 1; pl. 6, figs. 1, 2. Sphenodiscus pleurisepta (Conrad, 1857). Cobban and Kennedy, 1995: 12, fig. 8.5 (with full synonymy).

Sphenodiscus pleurisepta (Conrad, 1857). Kennedy et al., 1996: 11, figs. 4A, 5-12.

Sphenodiscus pleurisepta (Conrad, 1857). Kennedy et al., 1997: 9, figs. 9J, 11-14.

Sphenodiscus pleurisepta. Larson et al., 1997: 91. Sphenodiscus pleurisepta (Conrad, 1857). Landman and Cobban, 2003: 17, figs. 12-15.

TYPE: The holotype is USNM 9888, said to be from "Jacun, 3 miles below Laredo", but probably from the Escondido Formation of the Rio Grande Region, probably in Maverick County, Texas (Stephenson, 1941, 1955).

MATERIAL: There are four specimens:
AMNH 49412, 49417, 49420, and 49421 from AMNH loc. 3252 from the Severn Formation, Kent County, Maryland.

DESCRIPTION: AMNH 49412 is a fragment of a phragmocone slightly more than onehalf whorl long (fig. 10A-C). It is missing most of its venter on the adoral one-third whorl. The whorl width and height at the adapical end of the specimen are $7.8 \mathrm{~mm}$ and $25.7 \mathrm{~mm}$, respectively; the ratio of whorl width to height is 0.30 . The umbilicus is small but obscured by matrix. The whorl section is oxyconic. The inner flanks are slightly concave, the midflanks are broadly rounded, and the outer flanks gently slope to an acute venter. The ornament on the left side is better preserved. There are four radial swellings on the outer flanks, which become more widely spaced adorally. The distance between the two most adoral swellings is $8 \mathrm{~mm}$. It is possible that there are two swellings on the midflanks but the specimen is not well enough preserved to determine this. The suture has narrow-stemmed saddles with phylloidlike terminations (fig. 11).

There are three other specimens. AMNH 49421 is a small fragment of a phragmocone consisting of part of the outer flanks and acute venter (fig. 10F-H). Two radial swellings are present on the outer flanks with a distance of approximately $9 \mathrm{~mm}$ between them. AMNH 49420 is a worn piece of a phragmocone with a maximum preserved whorl height of $41.6 \mathrm{~mm}$ (fig. 10D, E). It shows faint swellings on the inner and middle flanks. AMNH 49417 is a small piece of a body chamber with an acute venter and weak swellings on the outer flanks (fig. 10I, J).

DisCUSSION: Although fragmentary, these specimens all show swellings on the outer flanks and, in a couple of instances, on the midflanks as well. This suggests that these specimens are Sphenodiscus pleurisepta rath-

Fig. 10. A-J. Sphenodiscus pleurisepta (Conrad, 1857), AMNH loc. 3252, Severn Formation, Kent County, Maryland. A-C. AMNH 49412. A, Right lateral; B, ventral; C, left lateral. D, E. AMNH 49420. D, Apertural; E, left lateral. F-H. AMNH 49421. F, Right lateral; G, ventral; H, left lateral. I, J. AMNH 49417. I, Lateral; J, ventral. K-O. Sphenodiscus sp., same locality as A-J. K. AMNH 49419, left lateral. L, M. AMNH 49415. L, Lateral; M, ventral. N, O. AMNH 49416. N, Ventral; O, lateral. All figures $\times 1$. 

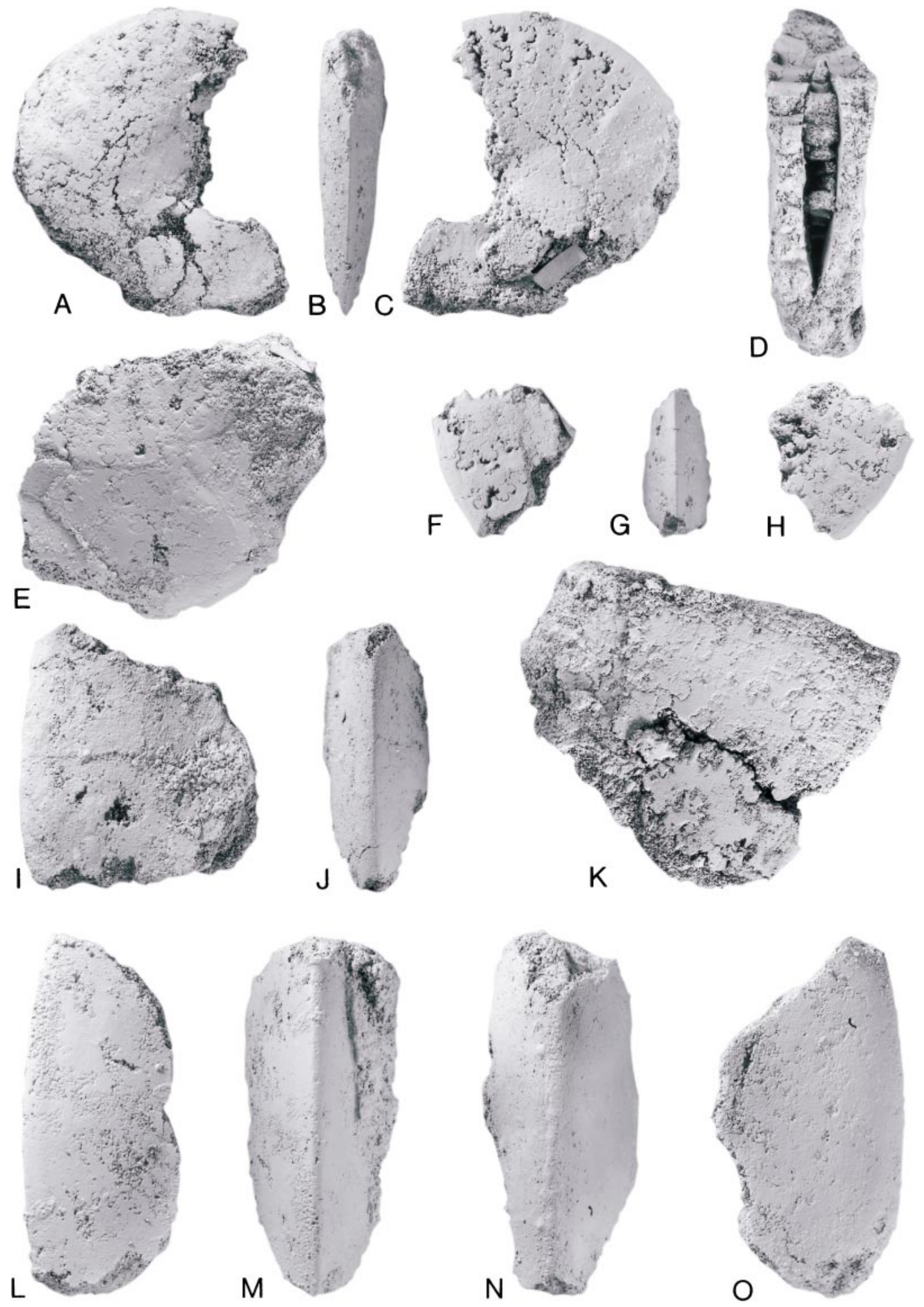


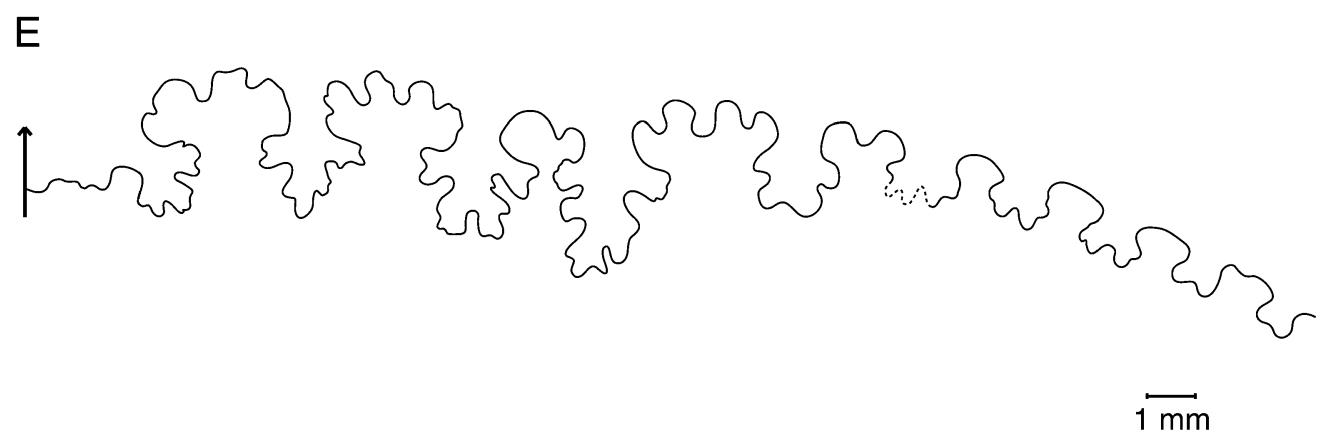

Fig. 11. Composite suture of Sphenodiscus pleurisepta (Conrad, 1857) at a whorl height of approximately 27 mm, AMNH 49412, AMNH loc. 3252, Severn Formation, Kent County, Maryland.

er than Sphenodiscus lobatus (Tuomey, 1856). Cobban and Kennedy (1995) discussed the synonymy of $S$. pleurisepta and its differences from congeneric species. Because this species has an unusually long range (the entire upper Maastrichtian), it is probably worthwhile in the future to more closely examine specimens of this species from the Gulf and Atlantic Coastal Plain and those from the Western Interior to confirm that they are all conspecific (N.L. Larson, personal commun., 2004).

OCCURRENCE: Severn Formation, Kent County, Maryland; Severn Formation, Prince Georges County, Maryland (Kennedy et al., 1997). This species occurs in New Jersey in the top of the New Egypt Formation and as reworked material in the base of the Hornerstown Formation, northeastern Monmouth County, and in the upper part of the New Egypt Formation, southwestern Monmouth County (Landman et al., in prep. a, c). It is known on the Gulf Coastal Plain from the Corsicana Formation in northeastern Texas (Kennedy and Cobban, 1993), the Owl Creek Formation in Missouri, Mississippi, and Tennessee (Kennedy and Cobban, 2000), and the Prairie Bluff Chalk in Mississippi (Cobban and Kennedy, 1995). It is also known from the Escondido Formation in Trans-Pecos Texas and northern Mexico (Stephenson, 1941, 1955). In the Western Interior, this species is reported from the Hoploscaphites birkelundae Zone of the Pierre Shale in Meade and Pennington Counties, South Dakota (Kennedy et al., 1996; Larson et al., 1997), the Fox Hills Formation in Niobrara County, Wyoming (Kennedy et al., 1996), and the up- per part of the Pierre Shale and Fox Hills Formation in Weld County, Colorado (Kennedy et al., 1996; Landman and Cobban, 2003).

\section{Sphenodiscus lobatus (Tuomey, 1856) Figure 12A, B}

Ammonites lenticularis Owen, 1852: 579, pl. 8, fig. 5.

Ammonites lobatus Tuomey, 1856: 168.

Sphenodiscus lobatus (Tuomey, 1856). Cobban and Kennedy,1995: 12, figs. 6.2, 6.3, 8.4, 8.6$8.11,12.18,12.19,16.16,16.17$ (with full synonymy).

Sphenodiscus lobatus (Tuomey, 1856). Kennedy and Cobban, 1996: 802, fig. 2.4-2.6, 2.13, 2.14, 2.19-2.21.

Sphenodiscus lobatus (Tuomey, 1856). Kennedy et al., 1997: 4, figs. 3-8, 9A-I, 10.

TYPE: The holotype, from Noxubee County, Mississippi, is lost (fide Stephenson, 1941: 434).

MATERIAL: There is one specimen (AMNH 48554) from the Peedee Formation, Brunswick County, North Carolina.

DESCRIPTION: AMNH 48554 is an internal mold $81.6 \mathrm{~mm}$ in diameter (fig. 12A, B). It is part of the phragmocone of a much larger specimen. A portion of the ventrolateral surface on the right side is covered by a bryozoan colony. There are two large circular depressions near the adoral end. The whorl section is oxyconic; the whorl width and height near the aperture are 14.9 and $47.2 \mathrm{~mm}$, respectively; the ratio of whorl width to height is 0.32. The umbilicus is small and bordered on the right side by the umbilical wall of the next whorl, most of which is missing. The 
inner flanks are slightly concave, the midflanks are broadly convex, and the outer flanks are nearly flat and converge to an acute venter. The surface of the shell is smooth without any trace of ornament.

OCCURRENCE: Peedee Formation, Brunswick County, North Carolina; Tinton Formation, near Tinton Falls, northeastern Monmouth County, New Jersey (Gallagher, 1993); Tinton Formation, near Freehold, central Monmouth County, New Jersey (Landman et al., in prep. b); upper part of the Navesink Formation and lower part of the New Egypt Formation, southwestern Monmouth County, New Jersey (Landman et al., in prep. c); base of the Hornerstown Formation, Gloucester County, New Jersey (Gallagher, 1993; Kennedy et al., 1995; Kennedy and Cobban, 1996); Severn Formation, Prince Georges County, Maryland (Kennedy et al., 1997); Corsicana Formation, northeast Texas (Kennedy and Cobban, 1993); upper part of the Ripley Formation, Mississippi; Prairie Bluff Chalk, Alabama, and Mississippi (Cobban and Kennedy, 1995); and Providence Sand, Chattahoochee River area, Alabama and Georgia. This species is also known from the Escondido Formation in Trans-Pecos Texas and northern Mexico. In the Western Interior, it occurs in the Hoploscaphites nicolletii and Jeletzkytes nebrascensis Zones of the Fox Hills Formation in north-central South Dakota (Landman and Waage, 1993) and in the J. nebrascensis Zone of the Pierre Shale in southeastern South Dakota and northeastern Nebraska (Kennedy et al., 1998).

\section{Sphenodiscus sp. \\ Figure 10K-O}

MATERIAL: There are seven specimens: AMNH 49413, 49415, 49416, 49418, 49419, and 50757, and USNM 522937 from AMNH loc. 3252 from the Severn Formation, Kent County, Maryland.

DESCRIPTION: AMNH 49415 and 49416 are ventral pieces of body chambers (fig. 10LO). The outer flanks converge to a relatively acute venter. There are no swellings on the flanks. AMNH 49413, 49418, and 49419 are worn pieces of large phragmocones (fig. 10K). USNM 522937 (not illustrated) is a piece of the venter of a body chamber 45.5 mm long.

Discussion: These specimens are too fragmentary for specific identification. However, they do not show any evidence of tubercles, suggesting kinship with Sphenodiscus lobatus.

OCCuRRence: Severn Formation, Kent County, Maryland.

\section{SUBORDER ANCYLOCERATINA WIEDMANN, 1966}

SUPERFAMILY TURRILITACEAE GILL, 1871

FAMILY BACULITIDAE GILL, 1871

Genus Baculites Lamarck, 1799

TyPe SPECIES: Baculites vertebralis Lamarck, 1801: 103, by subsequent designation by Meek, 1876: 391.

Baculites vertebralis Lamarck, 1801 Figures 13A-Z, a-f, 14A

Baculites vertebralis Lamarck, 1801: 103.

Baculites vertebralis Lamarck, 1801. Kennedy, 1986: 57, pl. 11, figs. 6-11; pl. 12, figs. 1-6; text-figs. 3a-d, 7d-f, 8 (with synonymy).

Baculites vertebralis Lamarck, 1801. Kennedy, in Kennedy et al., 1986: 1012, pl. 1, figs. 8, 9.

Baculites vertebralis Lamarck, 1801. Kennedy, 1987: 187, pl. 19, figs. 1-4, 7-10; pl. 20, figs. $3-5$; pl. 28 , figs. $2,7-10,14-16$; pl. 29 , figs. $1-5$; pl. 30, figs. $1-9$; text-figs. $11 \mathrm{a}, \mathrm{b}, 12$ (with full synonymy).

Baculites vertebralis Lamarck, 1801. Kennedy et al., 1997: 18, figs. 15E-J, M-O, 16A-F, I-K, $17,18$.

Baculites vertebralis Lamarck, 1801. Klinger and Kennedy, 2001: 215, figs. 160, 161.

TYPE: Lectotype, by the subsequent designation of Kennedy (1986: 57), is the original of Faujas-Saint-Fond (1799: pl. 21, figs. 2, 3).

MATERIAL: There are 30 specimens, mostly fragments of body chambers, all of which are internal molds, from AMNH loc. 3252, the Severn Formation, Kent County, Maryland: MAPS A2035c1-3, AMNH 47427, 49400, 49401, 49403-49405, 49408-49411, 49427, 49428, 50543, and 50683-50690, and USNM 522939-522944.

DESCRIPTION: The collection consists of robust and slender specimens, which may represent macroconchs and microconchs, re- 

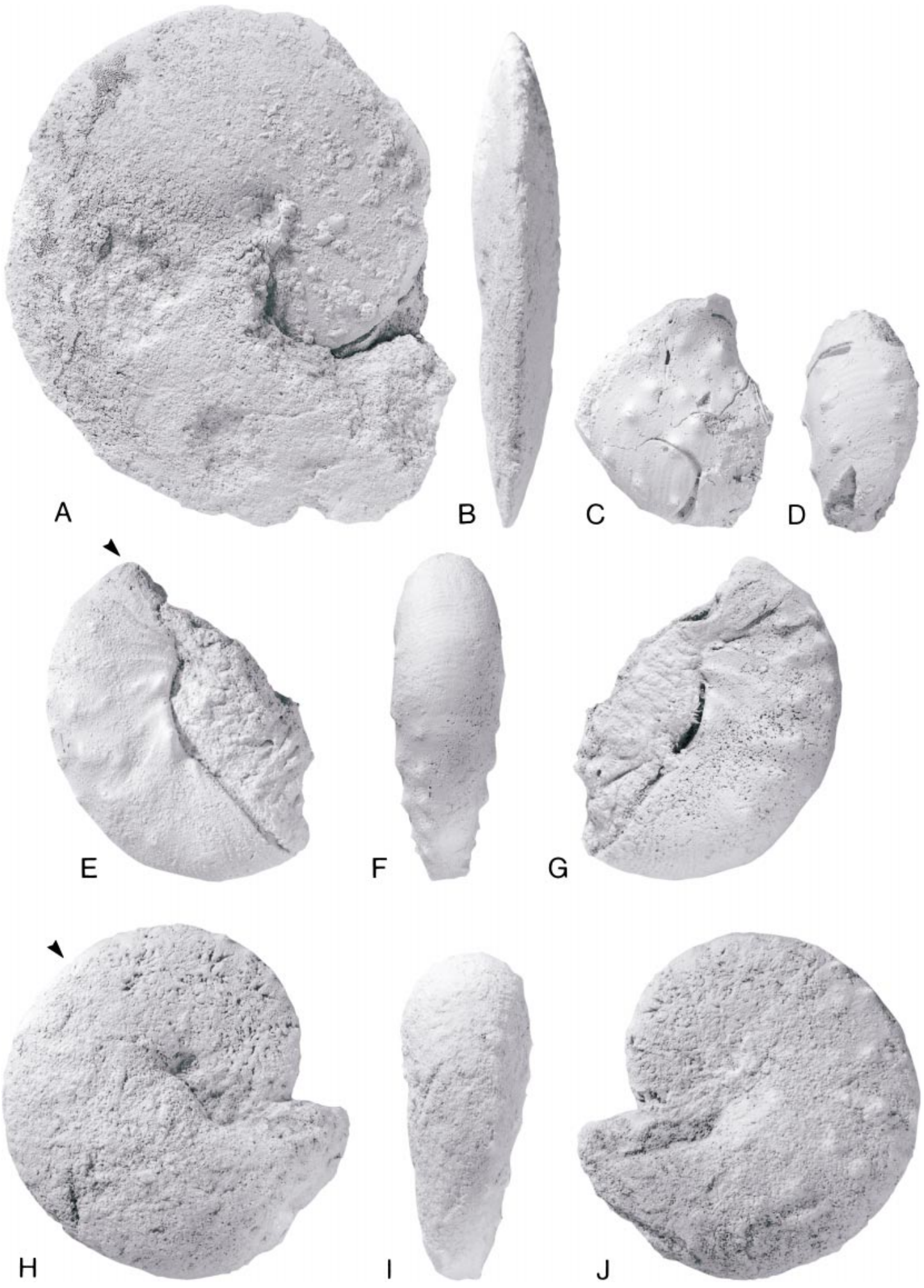
spectively. However, this is difficult to determine because the stage of ontogeny of each specimen is unknown (no evidence of septal approximation or apertural modification indicative of maturity). There are three robust specimens: MAPS A2035c1, 2, and AMNH 47428.

MAPS A2035c1 is a fragment of a body chamber $46.7 \mathrm{~mm}$ long with a taper angle of $5.0^{\circ}$ (fig. 13Q-T). The whorl section is compressed ovoid with maximum whorl width at midwhorl height; the ratio of whorl width to height near the adoral end is 0.62 . The dorsum is broadly rounded although it appears slightly angular due to crushing and wear on the dorsal half of the flanks on the left side. The flanks are broadly rounded and gently converge to an abruptly rounded ventrolateral shoulder and a narrow, broadly rounded venter. Ribs are absent on the dorsum but slant gently backward on the dorsal third of the flanks forming a broad concavity just dorsal of midflank. The rib index is approximately 5 based on the average distance between three consecutive ribs. Ribs break down into riblets on the ventral third of the flanks and slant strongly forward before disappearing on the ventrolateral shoulder.

MAPS A2035c2 is a fragment of a body chamber $35.3 \mathrm{~mm}$ long (fig. 13E-H). The whorl height is 22.8 and $19.8 \mathrm{~mm}$ at the adoral and adapical ends, respectively. The whorl section is compressed ovoid with maximum whorl width at midwhorl height; the ratio of whorl width to height at the adoral end is 0.60 . The dorsum is very broadly rounded, and the dorsolateral shoulder is fairly abruptly rounded. The dorsal half of the flanks are flat and subparallel and the ventral half of the flanks are broadly rounded, and converge to an abruptly rounded ventrolateral shoulder and a narrow, broadly rounded venter. Ribs cross the dorsum with a weak convexity; the rib index is approximately 6 based on the distance between two consecutive ribs. The flanks are covered with broad crescentic ribs with a rib index of approximately 7 based on the average distance between three consecutive ribs. The ribs project strongly forward on the outer third of the flanks and intersect the line of the venter at an angle of $39^{\circ}$. Very faint ribs are visible on the venter on the adapical end of the specimen.

AMNH 47428 is a small fragment of a body chamber $37.0 \mathrm{~mm}$ long (fig. 13I-L). It is slightly crushed and worn on the venter. The whorl section is compressed ovoid with a ratio of whorl width to height of 0.63 at the adoral end. The dorsum is very broadly rounded with a fairly abruptly rounded dorsolateral shoulder. The flanks are nearly flat and gently converge to a narrow, broadly rounded venter. Ribs cross the dorsum with a weak convexity; the rib index is approximately 7 based on the distance between two consecutive ribs. Ribs slant gently backward on the dorsal third of the flanks and merge to form weak nodelike swellings on the midflanks. The rib index on the dorsal third of the flanks is approximately 7 based on the average distance between five consecutive ribs. Ribs project strongly forward on the outer third of the flanks but are not preserved on the venter.

There are five good examples of fairly slender variants. MAPS A2035c3 is a small fragment of a body chamer $29.2 \mathrm{~mm}$ long (fig. 13A-D). The shell is slightly crushed laterally and shows a shallow constriction along the flanks at midwhorl height on the left side, which may represent a growth deformity. The whorl height is 17.3 and 15.5 $\mathrm{mm}$ at the adoral and adapical ends, respectively. The whorl section is compressed ovoid with a ratio of whorl width to height of 0.67 at the adoral end. The dorsum is broadly rounded, and the dorsolateral shoul-

$\leftarrow$

Fig. 12. Ammonites from the Peedee Formation, Todd Marl Pit off Todd Road, approximately $2 \mathrm{~km}$ west of the Shallotte River, Brunswick County, North Carolina. A, B. Sphenodiscus lobatus (Tuomey, 1856), AMNH 48554. A, Right lateral; B, ventral. C-J. Discoscaphites gulosus (Morton, 1834). C, D. AMNH 48557, fragment, probably a macroconch. C, Right lateral; D, ventral. E-G. AMNH 48553, microconch. E, Right lateral; F, ventral; G, left lateral. H-J. AMNH 48551, macroconch. H, Right lateral; I, ventral; J, left lateral. All figures $\times 1$. 

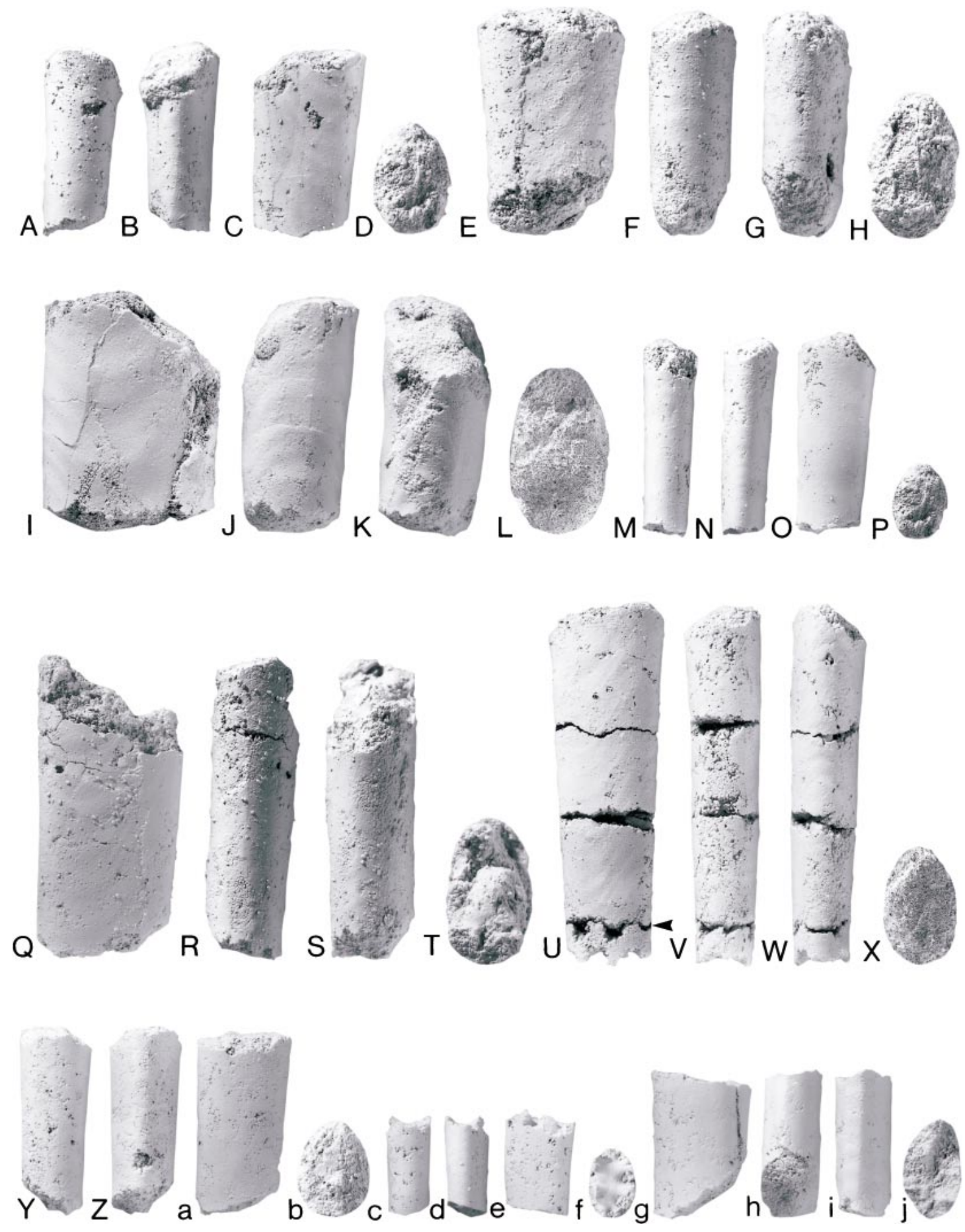

Fig. 13. A-Z, a-f. Baculites vertebralis Lamarck, 1801, AMNH loc. 3252, Severn Formation, Kent County, Maryland. A-D. MAPS A2035c3. A, Dorsal; B, ventral; C, left lateral; D, whorl cross section at adoral end. E-H. MAPS A2035c2. E, Right lateral; F, dorsal; G, ventral; H, whorl cross-section at adoral end. I-L. AMNH 47428. I, Right lateral; J, dorsal; K, ventral; L, whorl cross-section at adapical 
der is fairly abruptly rounded. The flanks are nearly parallel to just dorsal of midwhorl height and then converge more steeply toward the venter. The venter is narrow and sharply rounded although this may be due in part to lateral crushing. Faint ribs sweep strongly forward on the ventral two-thirds of the flanks; the rib index is 8 based on the average distance between three consecutive ribs.

AMNH 47427 consists of four pieces comprising the adapical part of the body chamber and last chamber of the phragmocone (fig. 13U-X). Altogether, it is $56.0 \mathrm{~mm}$ long with a taper angle of $5.7^{\circ}$. The whorl height is 18.2 and $13.5 \mathrm{~mm}$ at the adoral and adapical ends, respectively. The whorl section is compressed ovoid with maximum width at midwhorl height; the ratio of whorl width to height at the adoral end is 0.66 . The dorsum is wide and broadly rounded and the dorsolateral shoulder is fairly abruptly rounded. The dorsal half of the flanks are broadly rounded and divergent and the ventral half of the flanks are broadly rounded and converge to a fairly abruptly rounded ventrolateral shoulder and a narrow, broadly rounded venter. No ornament is visible on the dorsum and dorsal third of the flanks because this part of the specimen is worn. Ribs slant strongly forward on the ventral two-thirds of the flanks and intersect the line of the venter at an angle of $34^{\circ}$. The rib index is approximately 6 based on the distance between two consecutive ribs. Ribs cross the venter with a weak convexity; the rib index is approximately 6.5 based on the average distance between three consecutive ribs.

AMNH 49427 is a small fragment of a body chamber $31.2 \mathrm{~mm}$ long (fig. 13M-P). The whorl height is 12.1 and $10.1 \mathrm{~mm}$ at the adoral and adapical ends, respectively. The ratio of whorl width to height at the adoral end is 0.70. The whorl section is compressed ovoid with maximum width at midwhorl height. The dorsum is more broadly rounded than the venter, and the flanks are very broadly rounded to flat. The specimen is nearly smooth with very faint ribs on the ventral half of the flanks and venter. Ribs cross the venter with a marked convexity; the rib index is approximately 5.5 based on the average distance between three consecutive ribs.

AMNH 49411 is a small, worn fragment of a body chamber $29.0 \mathrm{~mm}$ long with a taper angle of $3.8^{\circ}$ (fig. 13Y, Z, a, b). The whorl height is 14.8 and $13.4 \mathrm{~mm}$ at the adoral and adapical ends, respectively. The ratio of whorl width to height at the adoral end is 0.77 . The whorl section is ovoid but slightly more tear-shaped than in other specimens in the collection. The dorsum is very broadly rounded, and the dorsolateral shoulder is well rounded. The dorsal half of the flanks are nearly flat and the ventral half of the flanks are broadly rounded and converge to a narrowly rounded venter. The specimen is smooth except for weak ribs on the venter.

AMNH 49408 is a very small, smooth septate fragment $15.3 \mathrm{~mm}$ long with a whorl height of $11.2 \mathrm{~mm}$ at the adoral end (fig. $13 \mathrm{c}-\mathrm{f})$. The ratio of whorl width to height is 0.67 . The whorl section is compressed ovoid with the dorsum more broadly rounded than the venter. The suture shows narrow, rectangular bifid lobes and saddles (fig. 14A).

USNM 522939-522944 (not illustrated) are fragments of body chambers 23.7-37.8 $\mathrm{mm}$ long, of which three are robust, one is intermediate, and two are slender.

OCCURREnCE: Severn Formation, Kent County, Maryland; Severn Formation, Prince Georges County, Maryland (Kennedy et al., 1997). Elsewhere on the Atlantic Coastal Plain, this species has been reported from the

$\leftarrow$

end. M-P. AMNH 49427. M, Dorsal; N, ventral; O, left lateral; P, whorl cross section at adoral end. Q-T. MAPS A2035c1. Q, Right lateral; R, dorsal; S, ventral; T, whorl cross section at adoral end. U-X. AMNH 47427. U, Right lateral; V, dorsal; W, ventral; X, whorl cross-section at adoral end. Y, Z, a, b. AMNH 49411. Y, Dorsal; Z, ventral; a, left lateral; b, whorl cross section at adoral end. c-f. AMNH 49408. c, Dorsal; d, ventral; e, left lateral; f, whorl cross section at adoral end. g-j. Eubaculites latecarinatus (Brunnschweiler, 1966), AMNH 49402, same locality as A-Z, a-f. g, Right lateral; h, dorsal; $\mathbf{i}$, ventral; $\mathbf{j}$, whorl cross-section at adoral end. All figures $\times 1$. 


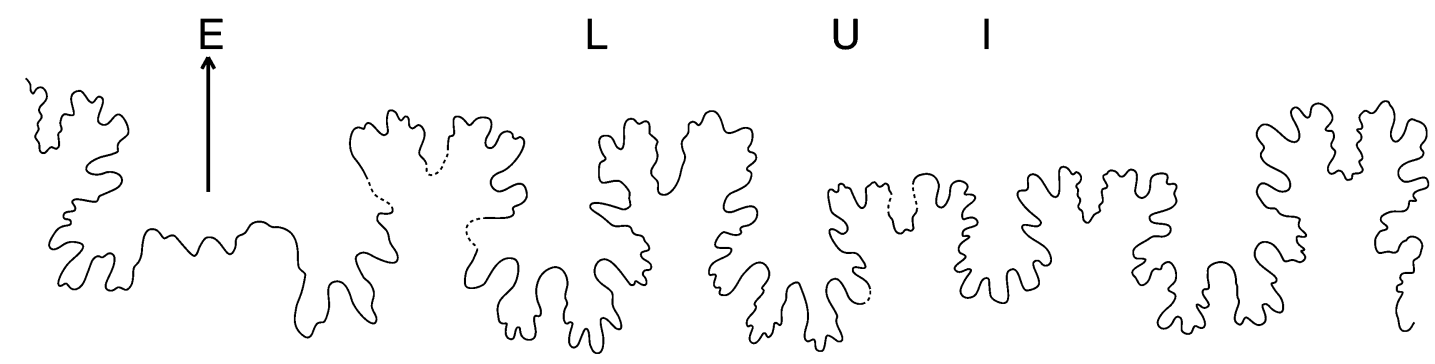

A

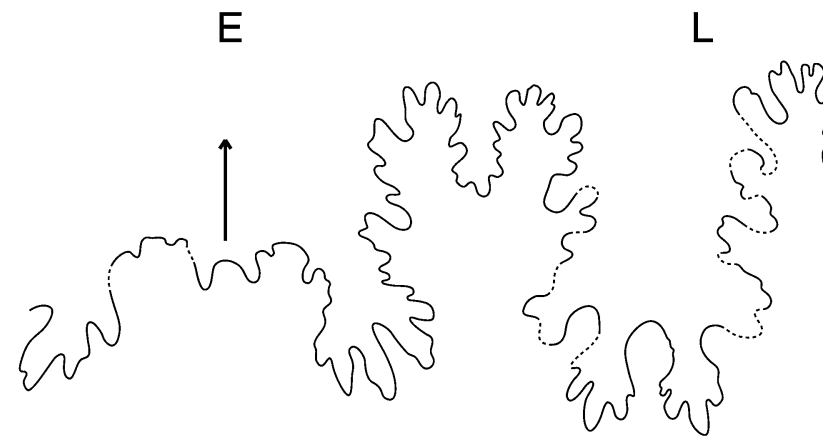

$U$

B

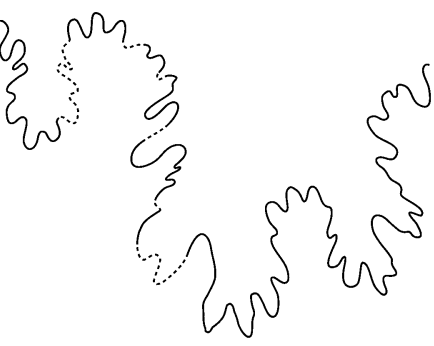

Fig. 14. A. Suture of Baculites vertebralis Lamarck, 1801, AMNH 49408, at a whorl height of 10.3 mm, AMNH loc. 3252, Severn Formation, Kent County, Maryland. B. Suture of Eubaculites latecarinatus (Brunnschweiler, 1966), AMNH 49402, at a whorl height of approximately $15 \mathrm{~mm}$, same locality as A.

upper part of the Navesink Formation and the lower part of the New Egypt Formation in Monmouth County, New Jersey (Landman et al., in prep. c). According to Kennedy et al. (1997), this species occurs in western Europe in the upper Maastrichtian Belemnitella junior and Belemnella kasimiroviensis belemnite zones. It is reported from the Maastricht area of Limburg, The Netherlands; the Cotentin Peninsula, Manche, France; Petites Pyrénées, Haute Garonne, France; Belgium; Denmark; southern Sweden; northern Germany; Poland; southern Russia; Ukraine; Turkmenia; Kazakstan; and Tunisia (see Klinger and Kennedy, 2001, for references).

Genus Eubaculites Spath, 1926

(= Giralites Brunnschweiler, 1966;

Cardabites Brunnschweiler, 1966;

Eubaculiceras Brunnschweiler, 1966)

TyPe SPECIES: Baculites vagina var. ootacodensis Stoliczka, 1866: 199, pl. 90, fig. 14, by original designation of Spath, 1926: 80; = Baculites labyrinthicus Morton, 1834: 44, pl. 13, fig. 10 .

\section{Eubaculites latecarinatus \\ (Brunnschweiler, 1966) \\ Figures 13g-j, 14B}

Eubaculites otacodensis (Stoliczka). Spath, 1940: 49 (pars), pl. 1, figs. 3a, b, text-fig. 1 b.

Giralites latecarinatus Brunnschweiler, 1966: 33, pl. 3, figs. 13, 14; pl. 4, figs. 1-5; text-figs. 17, 18.

Giralites quadrisulcatus Brunnschweiler, 1966: 35, pl. 4, figs. 11-14, text-fig. 20.

Eubaculites ambindensis Collignon, 1971: 18, pl. 646, fig. 2393.

Eubaculites latecarinatus (Brunnschweiler). Klinger, 1976: 91, pl. 40, fig. 1; pl. 41, fig. 3; pl. 42, figs. 2, 6; pl. 43, figs. 3, 4; text-figs. 11d-e.

Eubaculites latecarinatus (Brunnschweiler). Klinger and Kennedy, in Klinger et al., 1980: 296, figs. 2a-c, 3a-d, 4a-c, 5b. 
Eubaculites latecarinatus (Brunnschweiler, 1966). Henderson et al., 1992: 159, figs. 22L-N, 23N-P. Eubaculites latecarinatus (Brunnschweiler, 1966). Klinger and Kennedy, 1993: 238, figs. 26A, 39-41, 42B, C, 43-49, 50A, 52A.

Eubaculites latecarinatus (Brunnschweiler, 1966). Kennedy et al., 1997: 20, figs. 15A-D, K, L, 16G, H, 19.

Eubaculites latecarinatus (Brunnschweiler, 1966). Klinger and Kennedy, 2001: 234.

Eubaculites latecarinatus (Brunnschweiler, 1966). Klinger et al., 2001: 287, pl. 10, figs. 4-9, textfig. 6 .

TYPE: The holotype, by original designation, is the original of Brunnschweiler (1966: pl. 4, figs. 2-4) from the Maastrichtian of Western Australia.

MATERIAL: One specimen, AMNH 49402, an internal mold, from AMNH loc. 3252, the Severn Formation, Kent County, Maryland.

DESCRIPTION: AMNH 49402 is a small septate fragment $23.4 \mathrm{~mm}$ long (fig. $13 \mathrm{~g}-\mathrm{j}$ ). It is slightly crushed on the dorsum and right side. The whorl height is approximately 16.0 $\mathrm{mm}$ at the adoral end. The whorl section is ovoid with broadly rounded flanks. The venter is narrow and tabulate with fairly sharp margins and is slightly slanted toward the right side due to crushing. The venter is covered with faint ribs with a rib index of 6 based on the average distance between five consecutive ribs. The suture is poorly preserved with deeply incised lobes and saddles (fig. 14B).

DisCUSSION: Although this is a small specimen, it is identifiable by its smooth flanks and tabulate venter with weak ribs.

OCCURREnCE: Severn Formation, Kent County, Maryland; Severn Formation, Prince Georges County, Maryland (Kennedy et al., 1997). This species occurs in New Jersey in the top of the New Egypt Formation and as reworked material at the base of the Hornerstown Formation, near Eatontown, northeastern Monmouth County (Landman et al., in prep. a); in the top of the New Egypt Formation in the Crosswicks Creek Basin, southwestern Monmouth County (Landman et al., in prep. c); and in the top of the Tinton Formation and as reworked material at the base of the Hornerstown Formation near Freehold, central Monmouth County (Landman et al., in prep. b). Klinger and Kennedy
(2001) reported this species from the Maastrichtian of south India, Western Australia, Zululand, South Africa, the offshore Alphard Group, and Madagascar.

\section{Eubaculites carinatus (Morton, 1834) Figure 15P, Q}

Baculites carinatus Morton, 1834: 44, pl. 13, fig. 1. Baculites lyelli d'Orbigny, 1847: pl. 1, figs. 3-7. Baculites tippaensis Conrad, 1858: 334, pl. 3, fig. 27.

Baculites spillmani Conrad, 1858: 335, pl. 35, fig. 24.

Baculites sheromingensis Crick, 1924: 139, pl. 9, figs. 1-3.

Eubaculites lyelli (d'Orbigny, 1847). Kennedy, 1987: 195, pl. 27, figs. 5-8; pl. 32, figs. 13, 14 (with full synonymy).

Eubaculites carinatus (Morton, 1834). Henderson et al., 1992: 150, figs. 6F, G, 14-16, 17A-C, G-J, 18-20.

Eubaculites carinatus (Morton, 1834). Klinger and Kennedy, 1993: 218, text-figs. 7a-e, 21-30, 31a-g, 32-35, 36e, f, 37, 38, 42a, 52g, h.

Eubaculites carinatus (Morton, 1834). Kennedy and Cobban, 2000: 180, pl. 2, figs. 1-23, 27, 28, text figs. 3, 4 (with additional synonymy).

Eubaculites carinatus (Morton, 1834). Kennedy et al., 2001: 168, fig. 4a, e.

Eubaculites carinatus (Morton, 1834). Klinger et al., 2001: 286, pl. 9, figs. 1-7; pl. 10, figs. 13 ; text-fig. 5.

TYPE: The holotype, by monotypy, is ANSP 72866, the original of Morton (1834: pl. 13, fig. 1) from the Maastrichtian Prairie Bluff Chalk of Alabama.

MATERIAL: There is one specimen (USNM 525332) well enough preserved for positive identification from the Severn Formation, Round Bay, Anne Arundel County, Maryland.

DESCRIPTION: USNM 525332 is a piece of a robust body chamber with most of the dorsum and nearly all of the right side stuck in the matrix (fig. 15P, Q). It is approximately $37.1 \mathrm{~mm}$ long and is ornamented with coarse concave nodes on the dorsal two-thirds of the flanks. The distance between consecutive nodes is approximately $9.7 \mathrm{~mm}$, yielding a rib index of approximately 3. The ventral area is set off by a longitudinal groove, and the ventrolateral shoulder is fairly abruptly rounded; the venter is flat and smooth.

Discussion: The combination of coarse 
A
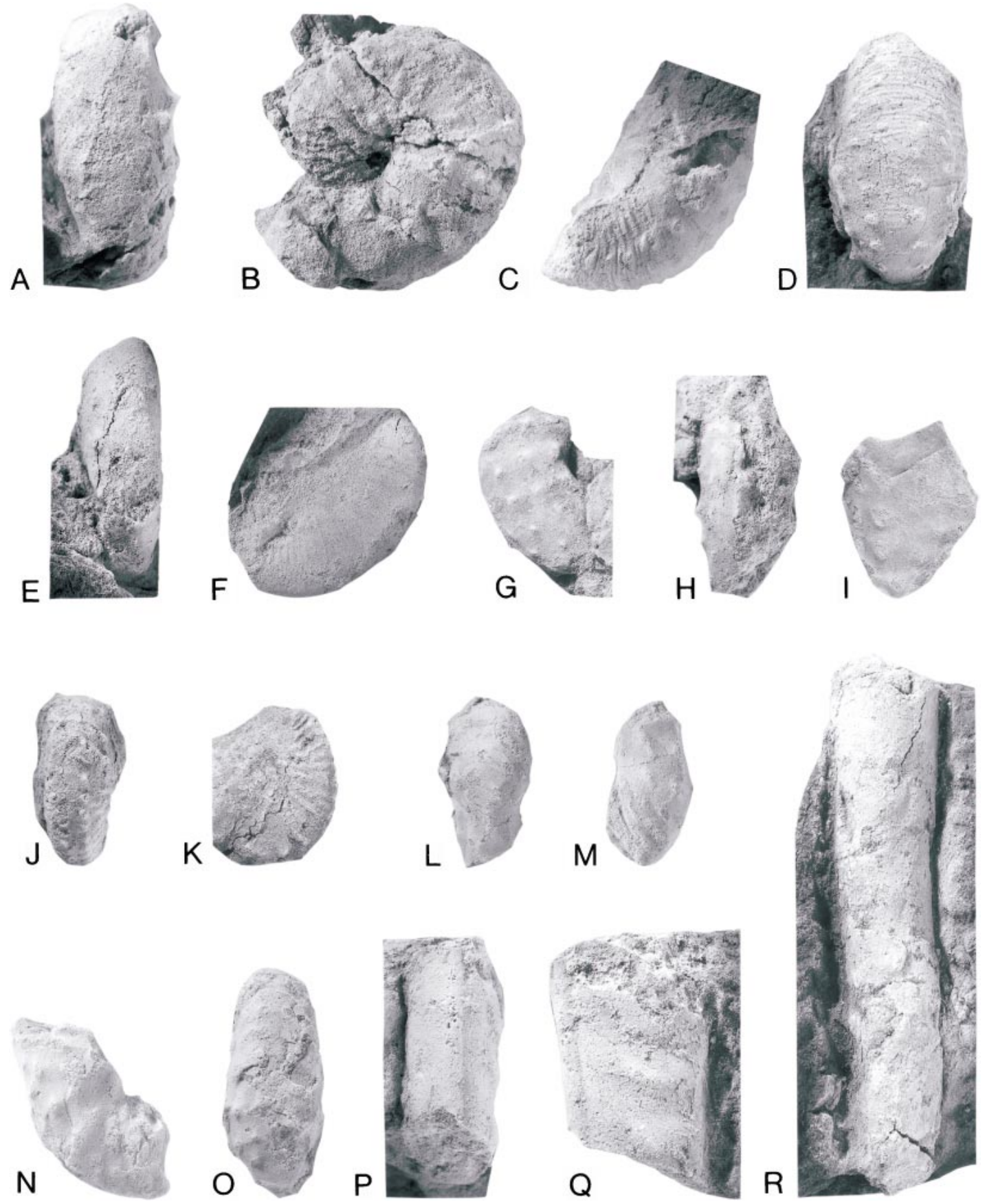

Fig. 15. Ammonites from the upper part of the Severn Formation, Round Bay, presumably on the western shore of the Severn River, Anne Arundel County, Maryland. A, B, G-O. Discoscaphites iris (Conrad, 1858). A, B. USNM 525325, macroconch. A, Ventral; B, left lateral. G, H. USNM 525329, microconch. G, Right lateral; H, ventral. I. USNM 525328, macroconch, right lateral. J, K. USNM 525330, fragment. J, Ventral; K, left lateral. L, M. USMN 525327, microconch. L, Ventral; M, left lateral. N, O. USNM 525326, microconch. N, Right lateral; O, ventral. C, D. Discoscaphites cf. D. iris (Conrad, 1858), USNM 525323, macroconch. C, Left lateral; D, ventral. E, F. Discoscaphites cf. D. 
nodes and a flat venter bordered by a longitudinal groove indicates that this specimen is Eubaculites carinatus.

OCCURRENCE: Severn Formation, Round Bay, Anne Arundel County, Maryland; Severn Formation, Prince Georges County, Maryland (Kennedy et al., 1997). This species occurs in New Jersey in the top of the New Egypt Formation and as reworked material at the base of the Hornerstown Formation, near Eatontown, northeastern Monmouth County (Landman et al., in prep. a); in the top of the New Egypt Formation in the Crosswicks Creek Basin, southwestern Monmouth County (Landman et al., in prep. c), and at the Inversand Pit, near Sewell, Gloucester County (Kennedy and Cobban, 1996); and at the top of the Tinton Formation and as reworked material at the base of the Hornerstown Formation near Freehold, central Monmouth County (Landman et al., in prep. b). Kennedy and Cobban (1996: 802, fig. 3.1-3.3, 3.7-3.12; see also Kennedy et al., 1995: figs. 4-6) recorded three specimens of this species (USNM 12691a-c), ex J.B. Marcou collection, labeled "New Jersey", which they inferred to be from the base of the Hornerstown Formation. This species is also reported from the top of the Corsicana Formation and base of the Kincaid Formation in Falls County, Texas (Kennedy et al., 2001); the Owl Creek Formation in Mississippi, Missouri, and Tennessee (Kennedy and Cobban, 2000); and the Prairie Bluff Chalk in Alabama and Mississippi (Cobban and Kennedy, 1995). Outside of North America, this species is reported from southeast France, Austria, the Netherlands, Zululand, South Africa, Mozambique, Madagascar, south India, Western Australia, Chile, Argentina, and California. It ranges from the upper lower to the upper upper Maastrichtian (Klinger et al., 2001).

Eubaculites cf. E. carinatus (Morton, 1834) Figure 15R

Compare:

Baculites carinatus Morton, 1834: 44, pl. 13, fig. 1.
Eubaculites carinatus (Morton, 1834). Kennedy and Cobban, 2000: 180, pl. 2, figs. 1-23, 27, 28, text figs. 3, 4 .

MATERIAL: There are two specimens (USNM 525333 and 525334) from the Severn Formation, Round Bay, Anne Arundel County, Maryland.

DESCRIPTION: USNM 525333 is a poorly preserved, somewhat distorted fragment, presumably of a body chamber, $83.4 \mathrm{~mm}$ long (fig. 15R). Most of what we interpret as the venter and all of the left side are stuck in the matrix. The dorsum is broadly rounded and the dorsal half of the flanks are ornamented with nodes with a rib index of approximately 2.5. However, the venter is not exposed and we cannot determine if it is tabulate.

USNM 525334 (not illustrated) is a fragment, presumably of a body chamber, 33.2 $\mathrm{mm}$ long. Although crushed, the dorsum seems broadly rounded and the venter seems tabulate. The flanks bear round, indistinct nodes with a rib index of approximately 2.5.

DisCUSSION: Both specimens are poorly preserved and incomplete but suggest kinship with Eubaculites carinatus.

OCCURRENCE: Severn Formation, Round Bay, Anne Arundel County, Maryland.

\section{SUPERFAMILY SCAPHITACEAE GILL, 1871 \\ FAMILY SCAPHITIDAE GILL, 1871}

SUBFAMILY SCAPHITINAE GILL, 1871

Genus Discoscaphites Meek, 1870

Type Species: Ammonites conradi Morton, 1834: 39, pl. 16, fig. 3, by original designation.

Discoscaphites gulosus (Morton, 1834) Figures 12C-J, 16

Ammonites conradi var. petechialis Morton, 1834: 39-40, pl. 16, fig. 1.

Ammonites conradi var. gulosus Morton, 1834: 39, pl. 16, fig. 2.

Ammonites conradi var. navicularis Morton, 1834: 40, pl. 19, fig. 4.

Discoscaphites gulosus (Morton, 1834). Landman

$\leftarrow$

minardi, n.sp., USNM 525324. E, Ventral; F, left lateral. P, Q. Eubaculites carinatus (Morton, 1834), USNM 525332. P, Ventral; Q, left lateral. R. Eubaculites cf. E. carinatus (Morton, 1834), USNM 525333, right lateral. All figures $\times 1$. 
and Waage, 1993: 212, figs. 156, 157, 159, 160, 167-180 (with full synonymy).

Discoscaphites gulosus (Morton, 1834). Cobban and Kennedy, 1995: 29, figs. 10.4, 10.5, 19.2019.24, 20.8-20.10, 20.14-20.17, 21.18-21.21.

Discoscaphites gulosus (Morton, 1834). Kennedy et al., 1997: 21, figs. 20K-O, 21D, E.

Discoscaphites gulosus (Morton, 1834). Kennedy et al., 2000: 26, fig. 9G-I.

TYPE: The holotype is ANSP 51552 from the Prairie Bluff Chalk at Prairie Bluff, Alabama.

MATERIAL: There are five specimens from the Peedee Formation, Brunswick County, North Carolina. Four of them (AMNH 48551, 48553, 48557, and 50328) were collected from the Todd Marl Pit, approximately $2 \mathrm{~km}$ west of the Shallotte River, and one of them (AMNH 50365) was collected from John D. Long County Park, Rt 33, 1.8 km south of Rt 17, near Wilmington.

MACROCONCH DESCRIPTION: AMNH 48551 is an internal mold of a macroconch $55.6 \mathrm{~mm}$ in diameter, missing part of the hook (fig. $12 \mathrm{H}-\mathrm{J})$. The umbilical seam of the body chamber is straight in side view. The whorl section at the base of the body chamber is compressed subquadrate with a ratio of whorl width to height of 0.58 . The flanks are subparallel and broadly rounded. The ventrolateral shoulder is abruptly rounded, and the venter is narrow and well rounded. The whorl section becomes more robust in passing into the body chamber; the ratio of whorl width to height at midshaft is 0.67 . The inner flanks are broadly rounded and divergent and the outer flanks are nearly flat and convergent. The ventrolateral shoulder is abruptly rounded and the venter is nearly flat.

The phragmocone bears ribs and tubercles, although the tubercles on the flanks are poorly preserved. The ventrolateral tubercles become more widely spaced toward the base of the body chamber; the distance between the two most adoral tubercles is $5.5 \mathrm{~mm}$. The ornament on the body chamber is slightly better preserved on the left side and consists entirely of tubercles. There is an umbilicolateral row, three flank rows, and a ventrolateral row. All of the tubercles are fairly strong, although eroded, and widely spaced. The tubercles on the outermost flanks are

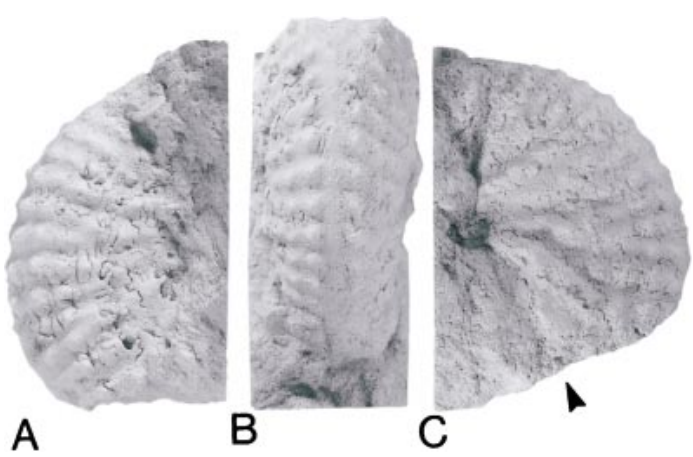

Fig. 16. Discoscaphites gulosus (Morton, 1834), AMNH 50365, macroconch, Peedee Formation, John D. Long County Park, Brunswick County, North Carolina. A, Right lateral; B, ventral; C, left lateral. All figures $\times 1$.

slightly more prominent than those on the ventrolateral margin.

AMNH 48557 is a fragment of the right side of the adoral part of the shaft of a body chamber, probably a macroconch (fig. 12C, D). Ribs swing forward crossing the venter with a weak adoral projection; there are 9 ribs/cm on the venter. Five rows of tubercles are present, including an umbilicolateral row, three flank rows, and a ventrolateral row. The umbilicolateral and outermost flank rows are the most prominent. The distance between consecutive tubercles in the outermost flank row is $9.2 \mathrm{~mm}$. The tubercles in the ventrolateral row are slightly more closely spaced with a distance between consecutive tubercles of approximately $7 \mathrm{~mm}$.

AMNH 50365 is a piece of a mature phragmocone and adapical part of a body chamber, probably of a macroconch, half of which is still stuck in the matrix (fig. 16). The umbilicus is exposed on the left side and is $4.0 \mathrm{~mm}$ in diameter. Part of the umbilical seam of the body chamber is preserved and is straight in side view. The whorl width and height near the adoral end of the phragmocone are 18.2 and $21.6 \mathrm{~mm}$, respectively; the ratio of whorl width to height is 0.84 . The flanks are broadly rounded, the ventrolateral shoulder is abruptly rounded, and the venter is nearly flat with a low "keel" in the middle. Ribs are strong, broad, and rectiradiate or prorsiradiate on the inner half of the flanks, with branching and intercalation at approximately midwhorl height. Ribs bear 
six rows of tubercles including the ventrolateral row. Tubercles in the outermost flank and ventrolateral rows are nearly equal in size; the distance between consecutive tubercles in each row is approximately $3 \mathrm{~mm}$. Outer ventrolateral tubercles are paired on either side of the venter with each pair connected by a low, broad rib.

MiCROCONCH DESCRIPTION: AMNH 48553 is an internal mold of a body chamber 54.4 $\mathrm{mm}$ long slightly crushed in on the adapical end (fig. 12E-G). The aperture is well preserved and shows a deep constriction and a moderately strong adoral projection of the venter. The whorl section is subquadrate at midshaft with an intercostal ratio of whorl width to height of 0.66 . The inner flanks are slightly concave and divergent and the outer flanks are broadly convex and convergent. The ventrolateral shoulder is fairly abruptly rounded and the venter is narrow and broadly rounded. The whorl section becomes more quadrate toward the aperture with an intercostal ratio of whorl width to height of 0.76 . The flanks are nearly flat and subparallel and the venter is broad and nearly flat.

The ornament is better preserved on the right side. A few ribs are present on the adapical end of the specimen. They appear at the umbilical shoulder and swing forward on the inner flanks, backward on the outer flanks, and then forward again on the ventrolateral shoulder. The umbilical shoulder bears three elongate bullae, the middle one of which is the most prominent. There are two rows of weak, irregularly spaced tubercles on the inner flanks, a row of stronger tubercles on the outer flanks, and a slightly weaker row of tubercles on the ventrolateral margin. The outer flank row consists of six more-or-less evenly spaced tubercles; the distance between consecutive tubercles at midshaft is $7 \mathrm{~mm}$. The ventrolateral row consists of eight tubercles, which are not as regularly spaced as those of the outer flank row; the distance between consecutive tubercles at midshaft is $5 \mathrm{~mm}$. Except for the adapical end of the specimen, the outer flank tubercles are stronger than the ventrolateral tubercles, but this may be an artifact of preservation. The outer flank tubercles extend slightly adoral of the ventrolateral tubercles and both rows disappear on the hook. The flanks of the hook are covered with dense ribs that swing slightly backward at the ventrolateral shoulder and then forward, crossing the venter with a moderately strong adoral projection. There are 10 or $11 \mathrm{ribs} / \mathrm{cm}$ on the venter.

Discussion: Of these specimens, only AMNH 50365 (fig. 16) is as highly ornamented as samples of this species from the Severn Formation (e.g., Kennedy et al., 1997: figs. 20K-O, 21D, E). AMNH 48553 (fig. 12E-G) displays an interesting combination of characters. The presence of multiple rows of tubercles plus closely spaced ribbing on the hook with a relatively strong adoral projection on the venter suggest kinship with Jeletzkytes (see, e.g., Kennedy et al. [1997: figs. 22A-C, 23D, E] for illustrations of Jeletzkytes nebrascensis from the Severn Formation). However, an important feature of this specimen is that the outer flank tubercles are stronger than the ventrolateral tubercles on most of the body chamber, which is more characteristic of Discoscaphites and Trachyscaphites than Jeletzkytes. We therefore treat this specimen as a microconch of D. gulosus, closely similar in morphology to the co-occurring macroconchs.

OCCURRENCE: Peedee Formation, Brunswick County, North Carolina; top of the New Egypt Formation and as reworked material at the base of the Hornerstown Formation, Monmouth County, New Jersey (Landman et al., in prep. a); New Egypt Formation, Gloucester County, New Jersey (Kennedy et al., 2000); Severn Formation, Prince Georges County, Maryland (Kennedy et al., 1997); and Prairie Bluff Chalk, Alabama and Mississippi (Cobban and Kennedy, 1995). In the Western Interior, Discoscaphites gulosus occurs in both the Hoploscaphites nicolletii and Jeletzkytes nebrascensis zones in the Fox Hills Formation, South Dakota (Landman and Waage, 1993).

Discoscaphites iris (Conrad, 1858)

Figures 15A, B, G-O, 17A-G, 18R

Scaphites iris Conrad, 1858: 335: pl. 35, fig. 23. Scaphites iris Conrad. Whitfield, 1892: 265, pl. 44, figs. 4-7.

Discoscaphites iris (Conrad). Stephenson, 1955: 134, pl. 23, figs. 23-30. 

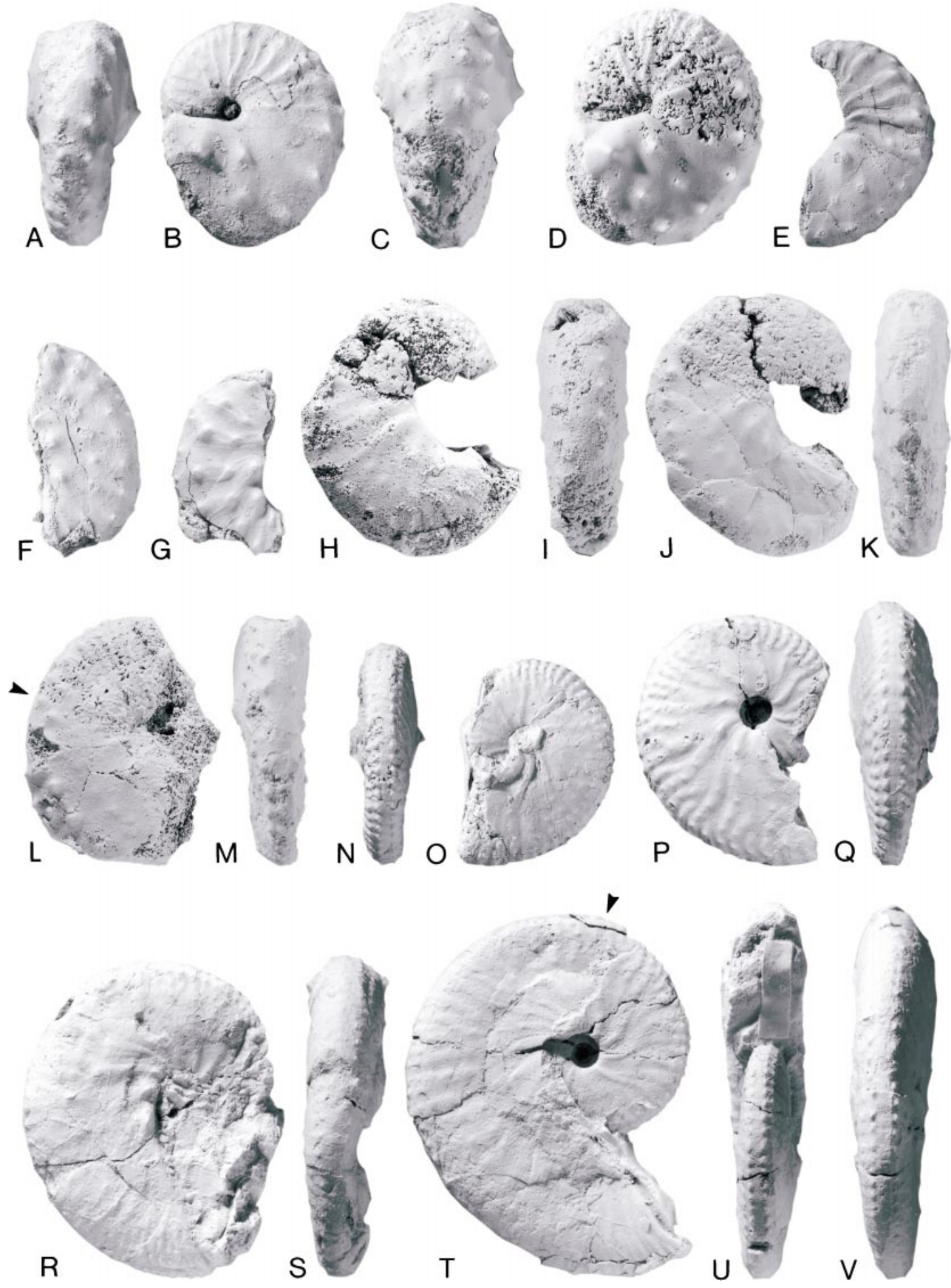
Discoscaphites iris (Conrad, 1858). Kennedy and Cobban, 2000: 183, pl. 3, figs. 3-35, text-fig. 5.

TYPE: The holotype, ANSP 50589, is the original illustrated in Conrad (1858: 335, pl. 35, fig. 23). It is from the bluffs of Owl Creek, Tippah County, Mississippi.

MATERIAL: There is one specimen (MAPS A2060c1) from the Severn Formation, AMNH loc. 3252, Kent County, and six specimens (USNM 525325-525330) from the Severn Formation, Round Bay, Anne Arundel County, Maryland. Three of the specimens from Round Bay (USNM 525326-525328) are pinkish-buff in color, suggesting that they are weathered. It is possible that they are from a different horizon than the other specimens from Round Bay, but there is only one label for the entire lot.

MACROCONCH DESCRIPTION: USNM 525325 is a fairly complete, although badly worn and slightly crushed, robust specimen $43.7 \mathrm{~mm}$ in diameter (fig. 15A, B). The right side of the phragmocone is still attached to the matrix. The phragmocone is ornamented with fairly coarse, flexuous ribs that bear four rows of tubercles of which the umbilicolateral and inner and outer ventrolateral tubercles are the most conspicuous. The distance between outer ventrolateral tubercles on the adapical end of the specimen is $2 \mathrm{~mm}$. The hook of the body chamber is eroded but the shaft preserves umbilicolateral, midflank, and inner ventrolateral tubercles, of which the umbilicolateral and midflank tubercles are the most prominent. The outer ventrolateral tubercles are worn away.

USNM 525328 is a crushed fragment of a body chamber, possibly of a macroconch, with what appear to be four rows of large, eroded tubercles (fig. 15I).

MAPS A2060c1 is a fragment of the midshaft of a large, slightly inflated body chamber with all of the right side missing (fig. $18 \mathrm{R})$. There is a row of umbilicolateral bullae and three rows of tubercles although almost all of the outer ventrolateral tubercles are worn away. Four prorsiradiate umbilicolateral bullae are spaced at approximately equal distances of 4-4.5 mm. Two relatively prominent midflank tubercles occur on the adapical portion of the specimen followed adorally by three much weaker, radial swellings spaced at distances of approximately 4 $\mathrm{mm}$. Five inner ventrolateral tubercles are preserved on the specimen and are evenly spaced at distances of $4.5-5.5 \mathrm{~mm}$. At midshaft, the distance between the umbilicolateral bullae and the midflank tubercles (6 $\mathrm{mm}$ ) is equal to that between the midflank tubercles and the inner ventrolateral tubercles, which is greater than that between the inner and outer ventrolateral tubercles (5 $\mathrm{mm})$.

MiCROCONCH DESCRIPTION: USNM 525326 is a worn, slightly distorted adoral piece of a body chamber $33.6 \mathrm{~mm}$ long (fig. $15 \mathrm{~N}, \mathrm{O}$ ). The ornament is better preserved on the right side. There are four rows of tubercles that

$\leftarrow$

Fig. 17. Comparison of three closely related species of Discoscaphites. A-G. Discoscaphites iris (Conrad, 1858). A, B. USNM 522952, macroconch, U.S. Geological Survey loc. 25423, Owl Creek Formation, Tippah County, Mississippi. A, Ventral; B, left lateral. C, D. AMNH 50538, macroconch, AMNH loc. 3345, top of New Egypt Formation and base of Hornerstown Formation, Monmouth County, New Jersey. C. Ventral; D, left lateral. E. USNM 522955, microconch, same loc. as A, B, left lateral. F. USNM 522956, microconch, same loc. as A, B, left lateral. G. USNM 522957, microconch, same loc. as A, B, right lateral. H-M. Discoscaphites minardi, n.sp., macroconchs, AMNH loc. 3252, upper part of Severn Formation, Lloyd Creek, Kent County, Maryland. H, I. AMNH 47288. H, Right lateral; I, ventral. J, K. AMNH 47293. J, Right lateral; K, ventral. L, M. AMNH 50542. L, Right lateral; M, ventral. N-V. Discoscaphites conradi (Morton, 1834). N, O. MAPS 2031a1, fragment, Severn Formation, exposures behind shopping center on south side of Central Avenue, just west of Beltway (Interstate 495), Randolph Village, Prince Georges County, Maryland. N, Ventral; O, left lateral. P, Q. MAPS A2031c2, fragment, Severn Formation, tributary of Cattail Brook, $1 \mathrm{~km}(0.6 \mathrm{mi})$ southwest of intersection of Sheriff and Brightseat roads, Brightseat, Prince Georges County, Maryland. P, Right lateral; Q, ventral. R, S. MAPS A2031c3, microconch, same loc. as P, Q. R, Right lateral; S, ventral. T-V. MAPS A2031c4, large macroconch, same loc. as P, Q. T, Right lateral; U, apertural; V, ventral. All figures $\times 1$. 

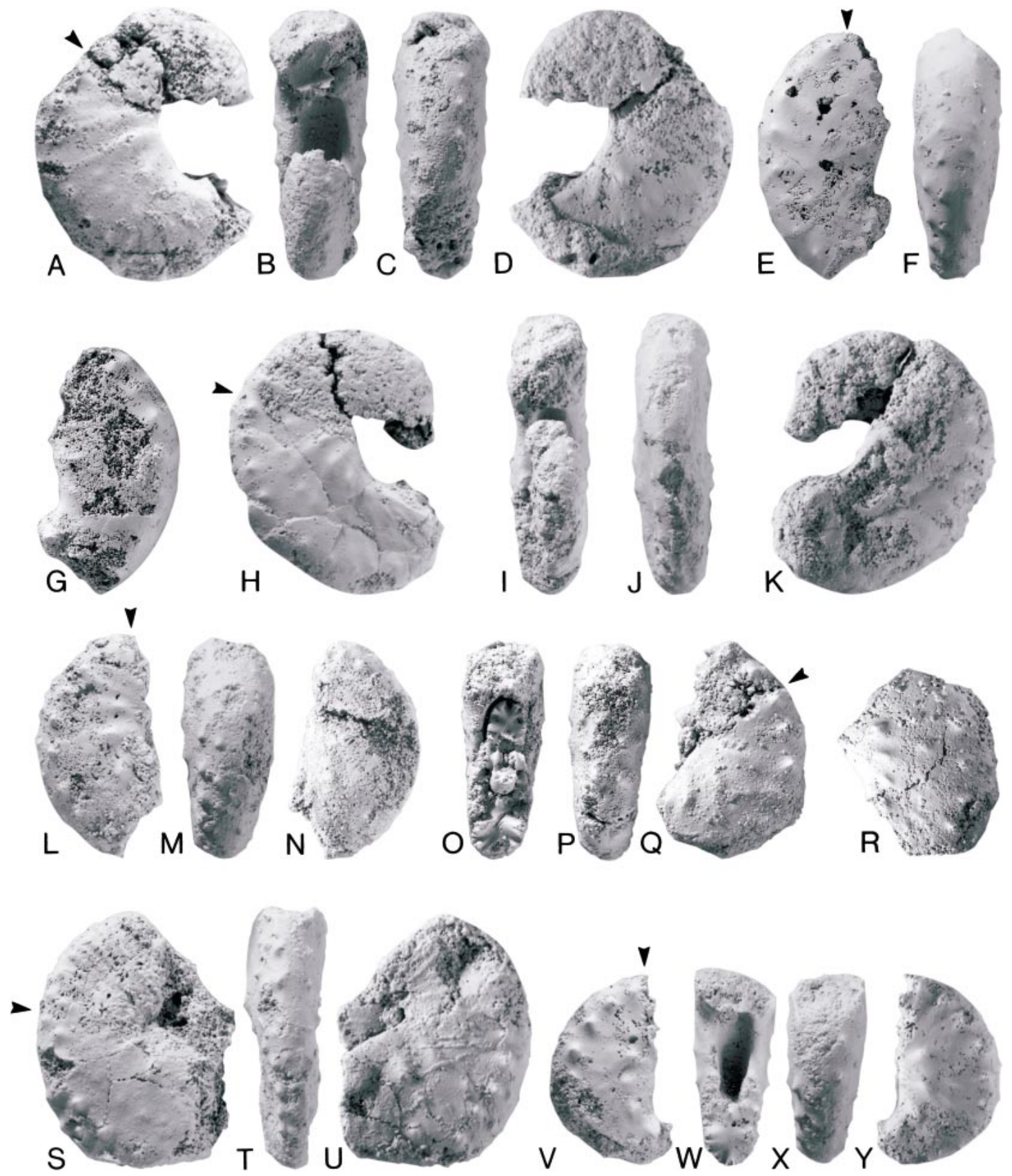

Fig. 18. A-Q, S-Y. Discoscaphites minardi, n.sp., macroconchs, AMNH loc. 3252, Severn Formation, Kent County, Maryland. A-D. Holotype, AMNH 47288. A, Right lateral; B, apertural; C, ventral; D, left lateral. E-G. AMNH 47281. E, Right lateral; F, ventral; G, left lateral. H-K. Paratype, AMNH 47293. H, Right lateral; I, apertural; J, ventral; K, left lateral. L-N. AMNH 47295. L, Right lateral; M, ventral; N, left lateral. O-Q. MAPS A2059a1. O, Apertural; P, ventral; Q, left lateral. S-U. Paratype, AMNH 50542. S, Right lateral; T, ventral; U, left lateral. V-Y. AMNH 47283. V, Right lateral; W, apertural; X, ventral; Y, left lateral. R. Discoscaphites iris (Conrad, 1858), MAPS A2060c1, same loc. as A-Q, S-Y, left lateral. All figures $\times 1$. 
occur on coarse, poorly defined ribs that become more closely spaced toward the aperture. Only two umbilicolateral tubercles are preserved. Of the other rows, the inner ventrolateral tubercles are the largest.

USNM 525329 is part of the adoral half of a body chamber with the left side still embedded in the matrix (fig. 15G, H). The umbilical seam is curved in side view and matches the curve of the venter, indicating it is a microconch. The umbilical wall is flat and gently inclined outward and the umbilical shoulder is abruptly rounded. The inner and middle flanks are nearly flat and slightly convergent and the outer flanks between the inner and outer ventrolateral tubercles are broadly rounded and more steeply convergent. The ventrolateral shoulder is fairly abruptly rounded and the venter is broadly rounded.

Four rows of tubercles are present. The umbilicolateral row is perched on the umbilical shoulder and consists of three tubercles, the middle one of which is the most prominent one on the specimen. There are four midflank, four inner ventrolateral, and five outer ventrolateral tubercles preserved. The outer ventrolateral tubercles are slightly more subdued than the inner ones. The distance between consecutive tubercles in each row is 5-5.5 $\mathrm{mm}$. The distance between tubercle rows on the middle of the specimen starting with the umbilicolateral tubercles is 5.5, 4.5, and $4 \mathrm{~mm}$. The distance between outer ventrolateral tubercles on either side of the venter is $4 \mathrm{~mm}$.

Discussion: Although fragmentary, all these specimens conform to the description of Discoscaphites iris, notably in having four fairly prominent rows of tubercles. They are indistinguishable from specimens of this species from the Owl Creek Formation, Mississippi (fig. 17A-G).

OCCURRENCE: Upper part of the Severn Formation, Kent and Anne Arundel Counties, Maryland. This species occurs in New Jersey in the top of the New Egypt Formation and as reworked material at the base of the Hornerstown Formation, near Eatontown, northeastern Monmouth County (Landman et al., in prep. a); in the top of the New Egypt Formation in the Crosswicks Creek Basin, southwestern Monmouth County (Landman et al., in prep. c); and in the top of the Tinton Formation and as reworked material at the base of the Hornerstown Formation near Freehold, central Monmouth County (Landman et al., in prep. b). It occurs on the Gulf Coastal Plain in the upper part of the Owl Creek Formation and as reworked material at the base of the Clayton Formation in Mississippi, Tennessee, and Missouri (Stephenson, 1955; Sohl, 1960, 1964; Kennedy and Cobban, 2000). This species denotes the D. iris Zone on the Gulf and Atlantic Coastal Plain, which represents the upper part of the upper Maastrichtian, corresponding to the upper part of calcareous nannofossil Subzone CC26b.

\section{Discoscaphites cf. D. iris (Conrad, 1858) Figure 15C, D}

Compare:

Scaphites iris Conrad, 1858: 335, pl. 35, fig. 23. Discoscaphites iris (Conrad, 1858). Kennedy and Cobban, 2000: 183, pl. 3, figs. 3-35, text-fig. 5.

MATERIAL: There is a single specimen (USNM 525323) from the Severn Formation, Round Bay, Anne Arundel County, Maryland.

DESCRIPTION: USNM 525323 is the adoral half of a robust body chamber with the dorsum still attached to the matrix (fig. 15C, D). Part of the aperture appears to be preserved on the right side. There is an umbilical bulge on the middle of the specimen on the left side indicating it is a macroconch. The inner and midflanks are well rounded with a swelling on the midflanks on the left side; the outer flanks between the inner and outer ventrolateral tubercles are broadly rounded to nearly flat. The ventrolateral shoulder is fairly abruptly rounded and the venter is nearly flat.

The preserved ornament consists of fine ribs, umbilical bullae, midflank bullae, and inner and outer ventrolateral tubercles. One prominent umbilical crescentic bulla appears near the dorsal margin on the middle of the specimen. Ribs are indistinct on the adapical half of the specimen, but are conspicuous on the hook. Ribs are sharp and thin and bear radial bullae on the midfanks. Ribs swing gently forward just dorsal of the row of inner ventrolateral tubercles, crossing the venter with a slight adoral projection; there are 12 
$\mathrm{ribs} / \mathrm{cm}$ on the venter. Seven inner ventrolateral tubercles are preserved on the left side spaced at distances of $4.5 \mathrm{~mm}$ on the adapical end of the specimen and $3 \mathrm{~mm}$ on the adoral end. They become smaller and slightly more bullate toward the aperture. There are nine outer ventrolateral tubercles preserved on the left side; they show the same spacing as the inner ventrolateral tubercles and become smaller and more closely spaced toward the aperture. On the adoral third of the body chamber coincident with the appearance of conspicuous ribbing, the rows of inner and outer ventrolateral tubercles, especially on the right side, are both shifted toward the venter, possibly due to a pathology.

Discussion: This specimen resembles Discoscaphites iris in its robust whorl section and well-developed rows of inner and outer ventrolateral tubercles. However, it differs in that the midflank tubercles are only represented by small bullae and that very fine ribs cover the adoral third of the specimen.

OCCURRENCE: Severn Formation, Round Bay, Anne Arundel County, Maryland.

\section{Discoscaphites minardi, new species}

Figures 17H-M, 18A-Q, S-Y, 19-22

TyPES: The holotype is AMNH 47288, a macroconch, and the paratypes are AMNH 47293 and 50542, both macroconchs, and AMNH 47289, 47292, and 47297, all microconchs, from AMNH loc. 3252, the Severn Formation, Kent County, Maryland.

Etymology: After James P. Minard, a geologist at the U.S. Geological Survey, who worked on the stratigraphy of the Atlantic Coastal Plain and discovered the locality where this species occurs.

MATERIAL: There are 32 specimens: 10 macroconchs (AMNH 47281, 47283, 47288, 47290, 47293, 47295, 47299, 49406, 50542, and MAPS A2059a1); 6 microconchs (AMNH 47286, 47289, 47292, 47294, 47297, and 49426); and 16 specimens too fragmentary to determine the dimorph (AMNH 47280, 47282, 47285, 47287, 47296, 47298, 47479, 49407, 49414, 4942225, 50536, and 50537, and USNM 522938), from AMNH loc. 3252, the upper part of the Severn Formation, Kent County, Maryland.

DiAGNOSIs: Relatively small, dimorphic species; flanks of body chamber are flat and subparallel to slightly convergent; ornament on body chamber consists of weak, slightly swollen prorsiradiate ribs bearing concave umbilicolateral bullae, very weak, radial midflank swellings, if any at all, and an approximately equal number of inner and outer ventrolateral tubercles; inner ventrolateral tubercles are as strong as or slightly stronger than the outer ventrolateral tubercles.

DESCRIPTION: This species is relatively small with the macroconch approximately 40 $\mathrm{mm}$ in maximum diameter and the microconch approximately two-thirds as large. The hook is only slightly reflected with an apertural angle in macroconchs of $40-50^{\circ}$. The shell is compressed with relatively flat flanks; the ratio of whorl width to height at midshaft averages approximately 0.70. There are four rows of tubercles on indistinct prorsiradiate ribs, which are more closely spaced near the aperture. The umbilicolateral bullae are crescentic and become progressively more prorsiradiate adorally. The midflank swellings are weak and elongated radially, although occasionally they are round. In a few instances, they do not exist at all, which may be due to poor preservation. The inner ventrolateral tubercles are usually pointed but sometimes are elongated radially. There are an equal number of outer ventrolateral tubercles, which are as strong as or slightly weaker than the inner ventrolateral tubercles. The tubercles in both rows are evenly spaced at distances of 4-5 $\mathrm{mm}$. The smallest distance between tubercle rows is between the rows of inner and outer ventrolateral tubercles (fig. 22). This distance is as little as half the distance between other, adjacent rows of tubercles. The position of the midflank swellings is approximately midway between the umbilicolateral bullae and the inner ventrolateral tubercles. However, there is some variation depending on the dimorph. In macroconchs, the midflank swellings are slightly closer to the inner ventrolateral tubercles, whereas in microconchs, they are midway between or closer to the umbilicolateral bullae. This difference is probably related to the difference in whorl height between dimorphs.

Because much of the fossil material is poorly preserved and fragmentary, we de- 
scribe several specimens to document the morphology of this species as fully as possible. Even so, there is no complete adult and only one specimen (AMNH 47289) preserves any details of the hook.

MACROCONCH DESCRIPTION: The holotype AMNH 47288 is an adult specimen $40.9 \mathrm{~mm}$ in maximum diameter with the adoral half of the phragmocone and most of the body chamber preserved except for part of the adapical quarter of the shaft and the venter of the hook (figs. 17H, I, 18A-D). The umbilical shoulder of the shaft is straight in side view. The whorl section at midshaft is relatively compressed with a slightly swollen outline. The whorl width and height at midshaft are 13.6 and $20.1 \mathrm{~mm}$, respectively; the ratio of whorl width to height is 0.68 . The umbilical wall is steep and sharply convex and the umbilical shoulder is abruptly rounded. The inner flanks are broadly rounded and gently divergent, the midflanks are nearly flat and gently convergent, and the outer flanks are broadly rounded and more steeply convergent. The ventrolateral shoulder is fairly abruptly rounded and the venter is very broadly rounded.

Part of the ornament is visible on the outer flanks and venter on the adapical portion of the preserved phragmocone. Ribs are prorsiradiate on the outermost flanks and link to small ventrolateral tubercles that are evenly spaced at distances of approximately 2.5 $\mathrm{mm}$. It is possible that there is a row of inner ventrolateral tubercles but they are difficult to detect because of poor preservation. Ribs are present on the venter of the most adapical part of the preserved phragmocone. They are evenly spaced at distances of $0.75 \mathrm{~mm}(\approx 14$ ribs $/ \mathrm{cm}$ ) and show a slight adoral projection.

The ornament on the body chamber is weak; the most obvious features are the umbilicolateral bullae and inner and outer ventrolateral tubercles. There are four umbilicolateral bullae on the right side that extend to the aperture. They are strong and arcuate at midshaft where they are evenly spaced at distances of approximately $4.5 \mathrm{~mm}$. They give rise to weak, straight prorsiradiate ribs. Faint radial swellings occur at midflank and are most noticeable on the adoral half of the shaft where they are spaced at distances of approximately $2.5 \mathrm{~mm}$. They may extend onto the hook but this is impossible to confirm because of poor preservation. There is a row of relatively prominent inner ventrolateral tubercles that are spaced at distances of approximately $4-5 \mathrm{~mm}$ at midshaft, becoming more closely spaced adorally. A row of slightly less prominent but equally spaced outer ventrolateral tubercles is also present. At midshaft, the distance between the umbilicolateral bullae and the midflank swellings $(6 \mathrm{~mm})$ is slightly greater than that between the midflank swellings and the inner ventrolateral tubercles $(5.5 \mathrm{~mm})$, which is, in turn, slightly greater than that between the inner and outer ventrolateral tubercles (4 $\mathrm{mm}$ ) (fig. 22). The venter is worn and does not preserve any ribbing.

Paratype AMNH 47293 is most of an adult $42.0 \mathrm{~mm}$ in maximum diameter (figs. $17 \mathrm{~J}, \mathrm{~K}$, $18 \mathrm{H}-\mathrm{K})$. It is missing most of the phragmocone, except for the adoral half, and most of the aperture, and it is badly worn on the left side. The body chamber occupies approximately one-half whorl; the apertural angle is $46^{\circ}$. The umbilical shoulder is straight in side view with a very slight bulge. The specimen is somewhat distorted but originally was very compressed. The whorl width and height at the base of the body chamber are 10.9 and $17.3 \mathrm{~mm}$, respectively; the ratio of whorl width to height is 0.63 . The whorl section is equally compressed at midshaft; the whorl width and height are 11.9 and 19.7 $\mathrm{mm}$, respectively; the ratio of whorl width to height is 0.60 . The umbilical wall is vertical and steeply convex and the umbilical shoulder is abruptly rounded. The inner flanks are broadly rounded, the midflanks are flat to slightly concave and gently convergent, and the outermost flanks between the inner and outer ventrolateral tubercles are broadly rounded and more steeply convergent.

The ornament is only preserved on the right side of the body chamber. Tubercles and bullae occur on weak, prorsiradiate ribs. There are four concave umbilicolateral bullae, the most adoral of which is the smallest and occurs at the apertural margin. They are evenly spaced at distances of 3.5-4 $\mathrm{mm}$ on the shaft and are linked by weak, straight prorsiradiate ribs to very weak, radial midflank swellings, of which five are visible spaced at distances of approximately $3 \mathrm{~mm}$ 

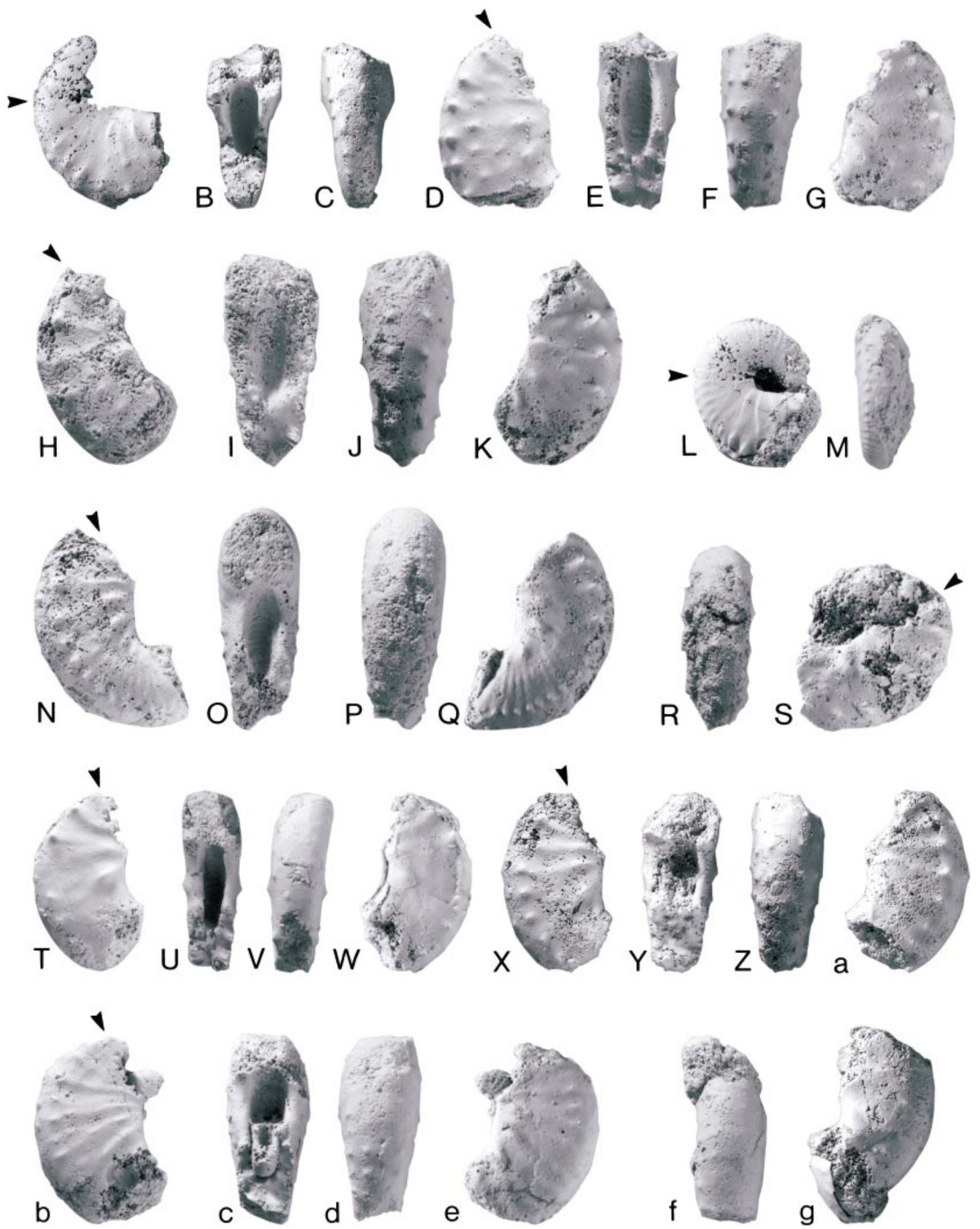

Fig. 19. Discoscaphites minardi, n.sp., AMNH loc. 3252, Severn Formation, Kent County, Maryland. A-K. Macroconchs. A-C. AMNH 49406. A, Right lateral; B, apertural; C, ventral. D-G. AMNH 47290. D, Right lateral; E, apertural; F, ventral; G, left lateral. H-K. AMNH 47299. H, Right lateral, I, apertural; J, ventral; K, left lateral. L-Z, a-g. Microconchs. L, M. AMNH 47294. L, Right lateral; M, ventral. N-Q, AMNH 47289. N, Right lateral; O, apertural; P, ventral; Q, left lateral. R, S. AMNH 
at midshaft. Due to poor preservation, it is difficult to determine if these midflank swellings extend onto the hook. Ribs are stronger and more closely spaced toward the aperture. There is a row of 13 inner ventrolateral tubercles (allowing for one lost due to preservation) that extend to the aperture (although the apertural lip is missing). These tubercles are evenly spaced on the shaft at distances of approximately $5 \mathrm{~mm}$ but become more closely spaced toward the aperture. A row of equally strong outer ventrolateral tubercles is also present but is worn away on most of the shell. On the adapical third of the body chamber where these tubercles are preserved, they are equal in number and spacing to the inner ventrolateral tubercles. At midshaft, the distance between the umbilicolateral bullae and the midflank swellings $(6 \mathrm{~mm})$ is slightly greater than that between the midflank swellings and the inner ventrolateral tubercles (5.5 $\mathrm{mm}$ ), which, in turn, is much greater than that between the inner and outer ventrolateral tubercles (3 mm) (fig. 22). No ribs are present on the venter, although most of the venter is worn away.

Paratype AMNH 50542 is a crushed piece of the adoral part of an adult phragmocone and adapical part of the body chamber (figs. $17 \mathrm{~L}, \mathrm{M}, 18 \mathrm{~S}-\mathrm{U})$. It was probably originally compressed. The phragmocone bears straight rectiradiate ribs that bifurcate on the outermost flanks. On the adapical part of the preserved phragmocone, only the outer ventrolateral tubercles are visible; they become slightly more widely spaced adorally so that the distance between the two most adoral tubercles on the phragmocone is $4 \mathrm{~mm}$. A row of inner ventrolateral tubercles appears at the adoral end of the phragmocone. The distance between inner ventrolateral tubercles at the base of the body chamber is $5 \mathrm{~mm}$.

The ornament on the body chamber consists of fairly strong, arcuate, umbilicolateral bullae, very faint swellings at approximately two-thirds whorl height, and fairly strong in- ner and outer ventrolateral tubercles. The umbilicolateral bullae are spaced at distances of 5.5-7.5 mm at midshaft. The midflank swellings, of which there are three, are more pronounced on the left side. The swellings are round and faint and are spaced at distances of 3.25-4 mm. The inner row of ventrolateral tubercles is slightly more prominent than the outer row. At midshaft, the inner ventrolateral tubercles are spaced at distances of $5 \mathrm{~mm}$ and the outer ventrolateral tubercles at distances of $6 \mathrm{~mm}$. The two rows are very close to each other so that in a few instances, tubercles from adjacent rows share a common base. On the adapical part of the body chamber on the left side where the tubercles in both rows can be counted, there are five tubercles in each row. At midshaft, the distance between the umbilicolateral bullae and the midflank swellings $(7 \mathrm{~mm})$ is much greater than that between the midflank swellings and the inner ventrolateral tubercles $(5 \mathrm{~mm})$, which is equal to that between the inner and outer ventrolateral tubercles (fig. 22). There is a single errant tubercle between the two ventrolateral rows on the right side, although it may be laterally displaced due to crushing. No ribs are preserved on the venter.

The rest of the macroconchs in the collection are fragmentary. We describe five of them to further document the morphology of the species. AMNH 47281 is a fragment of a compressed body chamber missing part of the adapical end and hook (fig. 18E-G). The umbilical wall is straight in side view. The whorl section at midshaft is compressed ovoid; the whorl width and height are 12.8 and $19.2 \mathrm{~mm}$, respectively; the ratio of whorl width to height is 0.67 . The umbilical wall is steep and sharply convex and the umbilical shoulder is abruptly rounded. The inner flanks are broadly rounded and gently divergent, the midflanks are flat and gently convergent, and the outermost flanks are very broadly rounded and more steeply conver-

47286. R, Ventral; S, left lateral. T-W. AMNH 47297. T, Right lateral; U, apertural; V, ventral; W, left lateral. X-Z, a. AMNH 49426. X, Right lateral; Y, apertural; Z, ventral; a, left lateral. b-e. AMNH 47292. b, Right lateral; c, apertural; d, ventral; e, left lateral. f, g. AMNH 47287. f, Ventral; g, left lateral. All figures $\times 1$. 

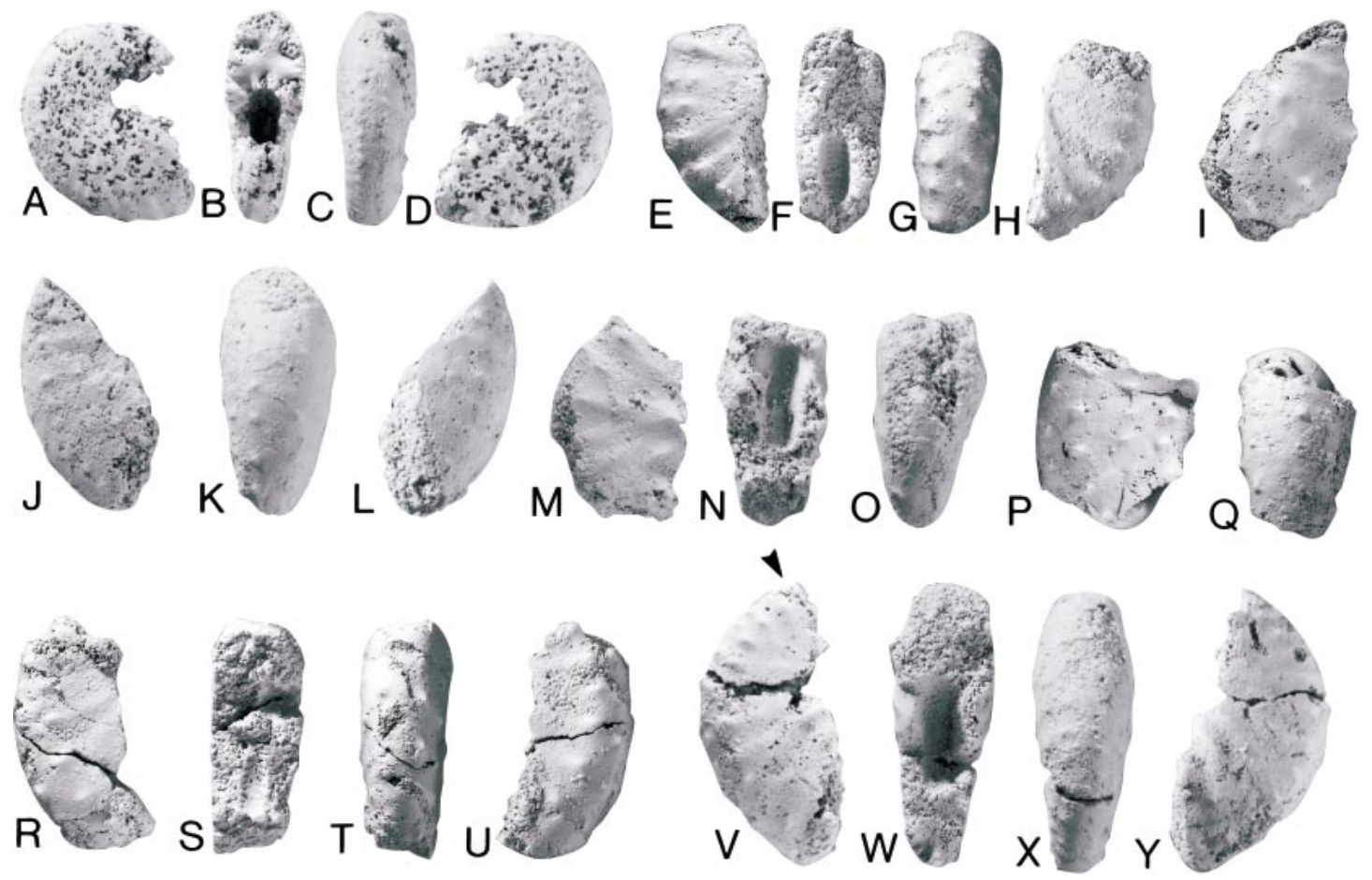

Fig. 20. Discoscaphites minardi, n.sp., dimorph indeterminate, AMNH loc. 3252, Severn Formation, Kent County, Maryland. A-D. AMNH 47298. A, Right lateral; B, apertural; C, ventral; D, left lateral. E-H. AMNH 49425. E, Right lateral, F, apertural; G, ventral; H, left lateral. I. AMNH 47296, left lateral. J-L. AMNH 47280. J, Right lateral; K, ventral; L, left lateral. M-O. AMNH 47479. M, Right lateral; N, apertural; O, ventral. P, Q. AMNH 49422. P, Right lateral; Q, ventral. R-U. AMNH 49424. R, Right lateral; S, apertural; T, ventral; U, left lateral. V-Y. AMNH 47285. V, Right lateral; W, apertural; X, ventral; Y, left lateral. All figures $\times 1$.

gent. The ventrolateral shoulder is fairly abruptly rounded and the venter is nearly flat.

The ornament on the body chamber is better preserved on the right side and consists of umbilicolateral bullae, very faint midflank swellings, inner and outer ventrolateral tubercles, and convex prorsiradiate ribs on the adoral half of the shaft. Three umbilicolateral bullae are present and are evenly spaced at distances of approximately $5 \mathrm{~mm}$. The midflank swellings are weak, radial, and occur on prorsiradiate ribs. Two swellings are visible spaced $5 \mathrm{~mm}$ apart. They are linked by ribs to the inner ventrolateral tubercles. Both rows of ventrolateral tubercles are well developed with the inner row being slightly stronger than the outer row. The distance between tubercles within each row is 4.5-5.5 $\mathrm{mm}$ with maximum spacing at midshaft. The numbers of inner and outer ventrolateral tu- bercles on the fragment are almost the same (8 inner, 9 outer ventrolateral tubercles). At midshaft, the distance between the umbilicolateral bullae and midflank swellings (8.5 $\mathrm{mm}$ ) is much greater than that between the midflank swellings and the inner ventrolateral tubercles $(5 \mathrm{~mm})$, which, in turn, is slightly greater than that between the inner and outer ventrolateral tubercles (4 mm) (fig. 22). The distance between outer ventrolateral tubercles on either side of the venter is 5 mm.

AMNH 47283 is most of the shaft of a body chamber missing the venter and outer flanks on the adoral end (fig. 18V-Y). The whorl section at the base of the body chamber is compressed ovoid; the whorl width and height are 9.1 and $13.9 \mathrm{~mm}$, respectively; the ratio of whorl width to height is 0.65 . The whorl section is slightly more depressed at 

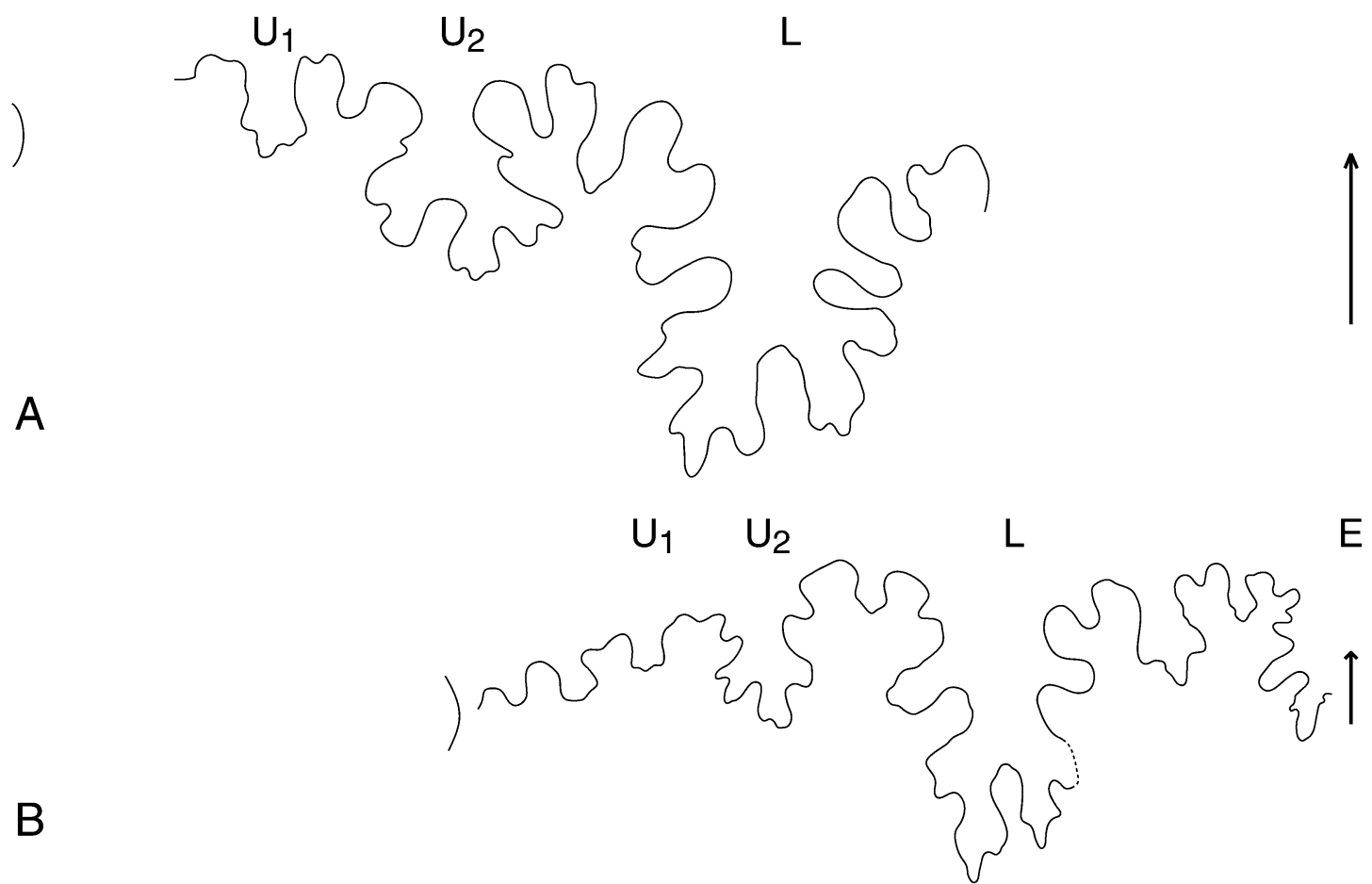

Fig. 21. Sutures of Discoscaphites minardi, n.sp., AMNH loc. 3252, Severn Formation, Kent County, Maryland. A. AMNH 47298, at a whorl height of approximately $12.0 \mathrm{~mm}$. B. AMNH 47294, last suture at a whorl height of $9.4 \mathrm{~mm}$.

midshaft; the whorl width and height are 11.4 and $16.1 \mathrm{~mm}$, respectively; the ratio of whorl width to height is 0.71 . The umbilical wall is steep and sharply convex and the umbilical shoulder is abruptly rounded. The inner flanks are broadly rounded and slightly divergent, the midflanks are nearly flat and slightly convergent, and the outermost flanks are broadly rounded and more steeply convergent. The ventrolateral shoulder is fairly abruptly rounded and the venter is broadly rounded to flat.

The body chamber is ornamented with umbilicolateral bullae, faint midflank swellings, and inner and outer ventrolateral tubercles. The ornament is slightly better preserved on the left side. There is a straight prorsiradiate rib connecting an umbilicolateral bulla and a midflank swelling just adoral of midshaft. The umbilicolateral bullae originate on the umbilical shoulder and become progressively more prorsiradiate adorally. The distance between umbilicolateral bullae at midshaft is $5 \mathrm{~mm}$. There are three weak, elongate swellings on the midflank starting just adoral of midshaft; they are spaced at equal distances of $2.5-3 \mathrm{~mm}$. The inner ventrolateral tubercles are much stronger than the midflank swellings. There are eight inner ventrolateral tubercles preserved on the body chamber fragment; they are spaced at equal distances of $4.5 \mathrm{~mm}$. The outer ventrolateral tubercles are slightly more subdued and are approximately evenly spaced at distances of 4.5-5.5 $\mathrm{mm}$. At midshaft, the distance between the umbilicolateral bullae and midflank tubercles $(5.5 \mathrm{~mm})$ is slightly greater than that between the midflank swellings and the inner ventrolateral tubercles $(5.0 \mathrm{~mm})$, which, in turn, is much greater than that between the inner and outer ventrolateral tubercles (3.5 mm) (fig. 22). Although the venter is smooth, it is raised into undulations connecting outer ventrolateral tubercles on either side of the venter on the adapical part of the specimen.

AMNH 49406 consists of the adoral part of the phragmocone and adapical part of the 


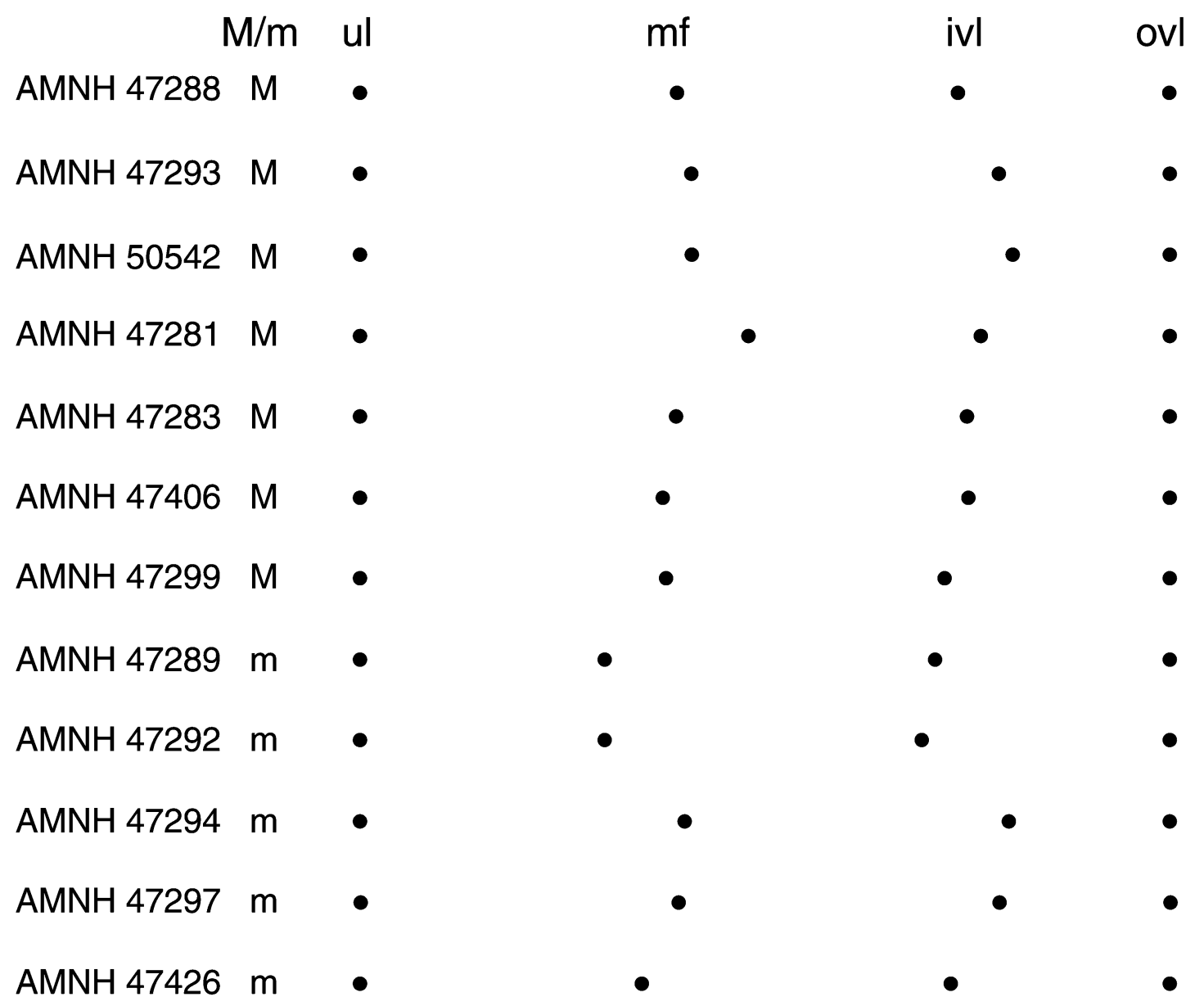

Fig. 22. Relative spacing of tubercle rows in Discoscaphites minardi, n.sp. In each specimen, the umbilicolateral bullae (ul) and outer ventrolateral tubercles (ovl) are plotted on the left and right side, respectively, with the midflank swellings ( $\mathrm{mf}$ ) and inner ventrolateral tubercles (ivl) in between. M, macroconch; m, microconch.

body chamber (fig. 19A-C). The right side is better preserved. The whorl section is compressed ovoid at midshaft. The umbilical wall is steep and convex and the umbilical shoulder is sharply rounded. The inner flanks are broadly rounded and divergent, the midflanks are flat to concave and convergent, and the outer flanks are broadly rounded and more steeply convergent. The ventrolateral shoulder is fairly abruptly rounded and the venter is flat.

The flanks of the phragmocone are covered with slightly swollen straight ribs. There are three crescentic umbilicolateral bullae on the body chamber that become progressively more prorsiradiate adorally. The bullae occur on widely spaced, straight to slightly sinuous, prorsiradiate ribs that link to inner ventrolateral tubercles. The two most adoral ribs bear feeble midflank swellings. The ribs weaken and the flanks become smoother in the region between the midflank swellings and the inner ventrolateral tubercles. The inner ventrolateral tubercles are radially elongated and first appear on the adapical part of the body chamber. They become progressively more widely spaced adorally; the distance between tubercles at midshaft is 4.5 $\mathrm{mm}$. The inner and outer ventrolateral tubercles are very close to each other so that in a few instances tubercles from adjacent rows share a common base. The outer ventrolateral 
tubercles first appear slightly adapical of the inner ventrolateral tubercles and are spaced somewhat unevenly with a maximum distance of $6 \mathrm{~mm}$ between tubercles just adapical of midshaft. The distance between the umblicolateral bullae and the midflank swellings $(4.5 \mathrm{~mm})$ is equal to that between the midflank swellings and the inner ventrolateral tubercles, which is much greater than that between the inner and outer ventrolateral tubercles (3 mm) (fig. 22). No ribbing is present on the venter.

AMNH 47299 is a fragment of the adapical half of a body chamber with the umbilical area worn away (fig. 19H-K). It is presumably a macroconch. The ornament is better preserved on the left side and consists of umbilicolateral bullae, midflank swellings, inner and outer ventrolateral tubercles, and prorsiradiate ribs. There are three concave umbilicolateral bullae spaced at approximately equal distances of $4.5-5.5 \mathrm{~mm}$. The most adoral bulla is the most prorsiradiate; the most adapical bulla occurs on a swollen rib, which is convex on the flanks and extends to an inner ventrolateral tubercle. Weak, straight prorsiradiate ribs extend across the midflanks at midshaft. Two swellings occur at midwhorl height, the adapical one of which is linked by a strongly convex rib to an inner ventrolateral tubercle. Both the inner and outer ventrolateral tubercles are equally strong and spaced at approximately equal distances of 5.5-6 $\mathrm{mm}$. The number of tubercles in each row is nearly the same ( 5 inner and 6 outer ventrolateral tubercles). Each outer ventrolateral tubercle is spaced slightly adapical of the adjacent inner ventrolateral tubercle. The distance between the umbilicolateral bullae and the midflank swellings $(5.5 \mathrm{~mm})$ is slightly greater than that between the midflank swellings and the inner ventrolateral tubercles $(5 \mathrm{~mm})$, which, in turn, is much greater than that between the inner and outer ventrolateral tubercles (4 mm) (fig. 22). The distance between outer ventrolateral tubercles on either side of the venter is $5.5 \mathrm{~mm}$. There are no ribs on the venter.

AMNH 47290 is the adapical half of a fairly robust body chamber (fig. 19D-G). The whorl section is subquadrate at midshaft; whorl width and height are 12.4 and 17.5 $\mathrm{mm}$, respectively; the ratio of whorl width to height is 0.71 . The umbilical wall is steep and convex, becoming more broadly rounded adorally; the umbilical shoulder is fairly abruptly rounded. The inner flanks are broadly rounded, the midflanks are nearly flat and slightly convergent, and the outermost flanks between the inner and outer ventrolateral tubercles are broadly rounded and more steeply convergent. The ventrolateral shoulder is fairly abruptly rounded and the venter is broadly rounded to flat.

The ornament is different on the right and left side. The left side bears four rows of tubercles with only a single row of two weak midflank tubercles on the adoral half of the specimen. In contrast, there are five rows of tubercles on the right side, including two rows of midflank tubercles on either side of midwhorl height. The more dorsal row, which more nearly corresponds to the midflank row on the left side, consists of three tubercles, one very weak and two slightly stronger, spaced at distances of $3.5 \mathrm{~mm}$ on the adoral end of the specimen. The more ventral row consists of five tubercles, which are as strong as the strongest tubercles in the more dorsal row, and are spaced at equal distances of $4 \mathrm{~mm}$ on nearly the entire specimen. Four umbilicolateral bullae are present on the right side with a spacing of $5 \mathrm{~mm}$ between consecutive bullae at midshaft. The inner and outer ventrolateral tubercles are slightly weaker than the umbilicolateral bullae but stronger than the midflank tubercles. There are six inner ventrolateral tubercles evenly spaced at distances of $4.75 \mathrm{~mm}$ on the right side. As shown on the left side (there is some erosion on the right side), the outer ventrolateral tubercles are as strong as the inner ones; they are spaced at distances of $3.75-5 \mathrm{~mm}$.

Microconch Description: Paratype AMNH 47297 is the adapical two-thirds of a body chamber of a flat-sided specimen missing part of the venter on the adapical end (fig. 19T-W). The whorl width and height at midshaft are 9.1 and $14.6 \mathrm{~mm}$, respectively; the ratio of whorl width to height is 0.62 . The umbilical wall is steep and sharply convex on the adapical part, becoming more broadly rounded and inclined outward at midshaft. Likewise, the umbilical shoulder becomes 
less abruptly rounded adorally. The midflanks are nearly flat to weakly concave and slightly convergent and the outer flanks between the inner and outer ventrolateral tubercles are more broadly rounded and more steeply convergent. The ventrolateral shoulder is fairly abruptly rounded and the venter is nearly flat.

The flanks are ornamented with swollen, widely spaced, straight to convex ribs that bear umbilicolateral bullae and inner ventrolateral tubercles. Three umbilicolateral bullae are preserved on the right side with a spacing of $6.5 \mathrm{~mm}$ between the two most adoral bullae. The tiny inner ventrolateral tubercles are irregularly distributed, perhaps due to a pathology, with the distance between tubercles equaling 5.5, 10, and $4 \mathrm{~mm}$, as measured in an adoral direction on the right side. The outer ventrolateral tubercles are very weak, probably due to poor preservation. They are approximately evenly spaced at distances of $5 \mathrm{~mm}$ at midshaft. There are very faint, radial midflank swellings on the adoral half of the specimen on the right side. The distance between the umbilicolateral bullae and midflank swellings $(4.75 \mathrm{~mm})$ is equal to that between the midflank swellings and the inner ventrolateral tubercles, which is greater than that between the inner and outer ventrolateral tubercles (2.5 mm) (fig. 22).

Paratype AMNH 47292 is most of the adapical half of a body chamber with part of the inner whorls attached (fig. 19b-e). The whorl section at midshaft is compressed ovoid; the whorl width and height are 11.4 and $16.6 \mathrm{~mm}$, respectively; the ratio of whorl width to height is 0.69 . The umbilical wall is steep and sharply convex and the umbilical shoulder is abruptly rounded. The inner flanks are broadly rounded and slightly divergent, the midflanks are nearly flat and slightly convergent, and the outer flanks are broadly rounded and more steeply convergent. The ventrolateral shoulder is fairly abruptly rounded and the venter is broadly rounded.

The flanks are ornamented with slightly swollen, weakly sinuous ribs that change from rectiradiate to prorsiradiate in an adoral direction. Umbilicolateral bullae become stronger and more prorsiradiate adorally and are evenly spaced at distances of approxi- mately $2.5 \mathrm{~mm}$. Ribs bifurcate on the midflanks and develop weak radial swellings. One such swelling is particularly prominent on the adoral end of the specimen on the left side. There are nine inner ventrolateral tubercles on the left side spaced at distances of $3-4.5 \mathrm{~mm}$ at midshaft. A row of two very faint swellings occurs just dorsal of the inner ventrolateral row on the right side. Most of the outer ventrolateral tubercles are not preserved, but on the adapical part of the specimen where they are present, they show approximately the same spacing as the inner ventrolateral tubercles-approximately $4 \mathrm{~mm}$ between consecutive tubercles just adapical of midshaft. The venter bears two swollen undulations on the adapical part of the specimen connecting outer ventrolateral tubercles on either side of the venter. The distance between the umbilicolateral bullae and the midflank swellings $(4 \mathrm{~mm})$ is slightly less than that between the midflank swellings and the inner ventrolateral tubercles $(5 \mathrm{~mm})$, which is slightly greater than that between the inner and outer ventrolateral tubercles $(4 \mathrm{~mm}$ ) (fig. 22).

Paratype AMNH 47289 consists of most of a body chamber, presumably of a microconch (fig. 19N-Q). However, the umbilical seam is straight in side view, suggesting that it could equally be an elongate macroconch. The impression of the phragmocone is visible and shows that there was no gap between the phragmocone and the hook. Parts of the dorsal projection and apertural constriction are present. The whorl section at midshaft is compressed ovoid; the whorl width and height are 11.3 and $15.6 \mathrm{~mm}$, respectively; the ratio of whorl width to height is 0.72 . The umbilical wall is steep and sharply convex at midshaft, becoming more broadly rounded near the aperture. Likewise, the umbilical shoulder becomes less abruptly rounded adorally. The inner flanks are broadly rounded, the midflanks are flat and subparallel, and the outer flanks are broadly rounded. The ventrolateral shoulder is fairly abruptly rounded and the venter is broadly rounded.

Ribs are swollen, widely spaced, prorsiradiate, and slightly sinuous on the shaft, becoming narrower, more closely spaced, more prorsiradiate, and straighter on the hook. Umbilicolateral bullae are approximately 
evenly spaced at distances of $3.5 \mathrm{~mm}$ at midshaft. As shown on the right side, the bullae become more closely spaced and weaken toward the aperture. On the adoral half of the shaft and hook, there are ten very weak, radial midflank swellings that persist to the aperture; they are evenly spaced on the hook at distances of $1-1.5 \mathrm{~mm}$. The inner ventrolateral tubercles, of which there are 15 preserved on the left side, are much stronger than the midflank swellings. They become more closely spaced, weaker, and smaller toward the aperture. The distances between tubercles at midshaft and at the aperture are 5 and $1.5 \mathrm{~mm}$, respectively. The tubercles occur on ribs on both the shaft and hook but the ribs tend to efface at midwhorl height on the shaft, giving the impression that the tubercles are not linked to the ribs, although they retain an elongate shape. The outer ventrolateral tubercles are similar to the inner ones and are only preserved on the adapical end of the specimen and on the hook. On the adapical end of the specimen, they are large and widely spaced (3.5-5 $\mathrm{mm}$ apart) and become smaller and more closely spaced (2$2.5 \mathrm{~mm}$ apart) on the hook. They occur on ribs linking the inner ventrolateral tubercles. The distance between the umbilicolateral bullae and the midflank swellings $(3.75 \mathrm{~mm})$ is less than that between the midflank swellings and the inner ventrolateral tubercles (5 $\mathrm{mm}$ ), which is greater than that between the inner and outer ventrolateral tubercles (3.5 mm) (fig. 22). The distance between outer ventrolateral tubercles on either side of the venter at midshaft is $6 \mathrm{~mm}$. There are weak, straight ribs on the venter just adapical of the aperture.

There are two other fragments of microconchs that help to further amplify the description of the species. AMNH 47294 is part of a phragmocone and adapical half of a body chamber (fig. 19L, M). The left side is completely worn away. The umbilical diameter at the base of the body chamber is $3.3 \mathrm{~mm}$. The whorl section is compressed ovoid. The umbilical wall is vertical and flat and the umbilical shoulder is sharply rounded. The inner flanks are broadly rounded, the midflanks are flat and subparallel, and the outermost flanks are broadly rounded and convergent. The ventrolateral shoulder is fairly sharply rounded and the venter is flat. The whorl section is similar at midshaft with a steeply convex umbilical wall.

The phragmocone is covered with slightly sinuous, prorsiradiate ribs. They are straight on the outermost flanks where they intercalate and branch, and straight on the venter with approximately $11 \mathrm{ribs} / \mathrm{cm}$. Each rib bears a tiny outer ventrolateral tubercle. The distances between tubercles at the adapical (broken) and adoral end of the phragmocone are 1 and $1.5 \mathrm{~mm}$, respectively. The row of inner ventrolateral tubercles is not as well defined as the row of outer ones. On the adapical portion of the body chamber, ribs are slightly concave on the outer half of the flanks, and they link inner and outer ventrolateral tubercles; ribs do not occur on the venter. Just adapical of midshaft, ribs are slightly concave on the inner flanks, where they develop into umbilicolateral bullae, and convex on the outer flanks, where they bear weak midflank swellings. The umbilicolateral bullae are initially slightly arcuate and become stronger, straighter, and more prorsiradiate adorally; they are evenly spaced at distances of 2-3 mm. Two radial midflank swellings occur on the adoral end of the body chamber fragment spaced $2.5 \mathrm{~mm}$ apart. Inner ventrolateral tubercles are faint and elongate on the adapical part of the body chamber but become stronger, more radial, and more widely spaced adorally, with a distance of $2.25 \mathrm{~mm}$ between the two most adoral tubercles. Outer ventrolateral tubercles are present on the entire piece of body chamber and gradually become more widely spaced adorally with a distance of $2.0 \mathrm{~mm}$ between consecutive tubercles on the adoral end of the specimen. On the adapical part of the body chamber, outer ventrolateral tubercles are linked to inner ventrolateral tubercles by prorsiradiate ribs, but on the adoral part, outer ventrolateral tubercles occur in the gaps between inner ventrolateral tubercles. The distance between the umbilicolateral bullae and the midflank swellings $(4 \mathrm{~mm})$ is equal to that between the midflank swellings and the inner ventrolateral tubercles, which is greater than that between the inner and outer ventrolateral tubercles ( $2 \mathrm{~mm}$ ) (fig. 22). The last suture at a whorl height of $9.2 \mathrm{~mm}$ shows 
an asymmetrically bifid first lateral lobe (fig. 21B).

AMNH 49426 is most of the shaft of a body chamber (fig. 19X-Z, a). The umbilical shoulder is curved in side view. The whorl section at midshaft is subquadrate; the whorl width and height are 10.6 and $15.2 \mathrm{~mm}$, respectively, in intercostal section, and 11.8 and $15.2 \mathrm{~mm}$, respectively, in costal section; the ratio of whorl width to height is 0.70 in intercostal section and 0.78 in costal section. The umbilical wall is steep and convex and the umbilical shoulder is abruptly rounded. The inner flanks are broadly rounded and slightly divergent, the midflanks are flat and gently convergent, and the outer flanks are broadly rounded and more steeply convergent. The ventrolateral shoulder is fairly abruptly rounded and the venter is broadly rounded.

The flanks are covered with slightly swollen, weakly sinuous, prorsiradiate ribs bearing umbilicolateral bullae and inner ventrolateral tubercles. On the adapical half of the specimen, the sinuosity of the ribs is well expressed; the ribs are concave on the inner flanks and convex on the midflanks. The ribs fade out on the adoral half of the specimen, but this may be due to poor preservation. The umbilicolateral bullae are crescentic and become markedly more prorsiradiate and slightly more widely spaced adorally; the distance between bullae at midshaft is $4 \mathrm{~mm}$. There is a row of faint midflank swellings most of which occur on ribs on the adapical two-thirds of the specimen. The inner ventrolateral tubercles, of which there are six preserved on the left side, are elongated radially and are approximately evenly spaced at distances of $4.5 \mathrm{~mm}$. There are slightly fewer outer ventrolateral tubercles (five of them preserved on the left side) evenly spaced at distances of $4.5-5 \mathrm{~mm}$ with the exception of the two most adapical tubercles, which are spaced $7.5 \mathrm{~mm}$ apart. The venter is smooth except for one rib near the adoral end of the specimen; it is straight across the venter. The distance between the umbilicolateral bullae and midflank swellings (4.5 $\mathrm{mm}$ ) is less than that between the midflank swellings and inner ventrolateral tubercles (5 $\mathrm{mm}$ ), which is greater than that between the inner and outer ventrolateral tubercles (3.5 mm) (fig. 22). The distance between outer ventrolateral tubercles on either side of the venter at midshaft is $5.25 \mathrm{~mm}$.

DIMORPH INDETERMINATE: We describe four specimens that are too fragmentary to determine the dimorph but nevertheless reveal details of the ornamentation. AMNH 47298 is part of a phragmocone with the sutures somewhat corroded (fig. 20A-D). The whorl width and height on the middle of the specimen are 6.7 and $9.8 \mathrm{~mm}$, respectively; the ratio of whorl width to height is 0.68 . The whorl section is compressed ovoid with broadly rounded flanks and flat venter. The flanks bear straight prorsiradiate ribs, although they are poorly preserved. On the adapical half of the specimen, the venter is covered with short straight ribs that disappear adorally; there are approximately 10 $\mathrm{ribs} / \mathrm{cm}$ on the venter based on the average distance between five consecutive ribs. A possible umbilicolateral bulla appears on the adoral end of the specimen. Inner ventrolateral tubercles appear on the adoral oneeighth of the specimen; the distance between tubercles at the adoral end is $2.5 \mathrm{~mm}$. Outer ventrolateral tubercles are present on the entire fragment and become progressively more widely spaced adorally; the distances between tubercles on the adapical and adoral ends are 1 and $3 \mathrm{~mm}$, respectively. The tubercles are mostly paired on either side of the venter and are connected by short ribs on the adapical half of the specimen. The suture at a whorl height of approximately $12 \mathrm{~mm}$ is moderately incised and shows a bifid first lateral lobe (fig. 21A).

AMNH 49425 is a fragment of a body chamber with part of the flanks and venter preserved (fig. 20E-H). There are some iridescent patches on the specimen suggesting the presence of a very thin layer of shell. The flanks bear prorsiradiate, slightly swollen, weakly sinuous, fairly widely spaced ribs that terminate in fairly strong inner ventrolateral tubercles, which connect in turn with equally strong outer ventrolateral tubercles. The tubercles in each row are spaced at distances of approximately 3-4 $\mathrm{mm}$; the fragment preserves six tubercles in each row. Two narrow radial swellings occur just dorsal of the inner ventrolateral tubercles on the adoral end of the specimen on the left side, and 
a single swelling occurs in the same position on the right side.

AMNH 49422 is a fragment of a body chamber with a snail stuck in the adoral end; the left side of the specimen is worn away (fig. 20P, Q). The ornament consists of four rows of sharp tubercles, although the midflank tubercles are elongated radially. The umbilicolateral tubercles are relatively strong and slightly arcuate with steep adapical and more gently sloping adoral sides. They are evenly spaced at distances of 3-4 $\mathrm{mm}$. The midflank tubercles are weaker, thinner, and prorsiradiate; they are evenly spaced at distances of 3-3.5 mm. The inner ventrolateral tubercles are stronger and more conical than the midflank tubercles and are spaced at approximately equal intervals of $4.5 \mathrm{~mm}$. One of these tubercles on the adoral end sits on a sharp prorsiradiate rib. The outer ventrolateral tubercles are slightly weaker than the inner ventrolateral ones but show the same distribution. The distance between the umbilicolateral bullae and midflank tubercles (4.5 $\mathrm{mm}$ ) is slightly less than that between the midflank tubercles and the inner ventrolateral tubercles $(5 \mathrm{~mm})$, which is greater than that between the inner and outer ventrolateral tubercles $(4 \mathrm{~mm})$. The distance between ventrolateral tubercles on either side of the venter is $5.5 \mathrm{~mm}$.

AMNH 47285 is the adapical half of a body chamber with most of the umbilical area missing (fig. 20V-Y). The whorl width and height at midshaft are 10.7 and $14.9 \mathrm{~mm}$, respectively; the ratio of whorl width to height is 0.72 . The body chamber is ornamented with slightly swollen, weakly sinuous, widely spaced ribs that become progressively more prorsiradiate adorally and bear umbilicolateral bullae and inner ventrolateral tubercles. The umbilicolateral bullae are crescentic and are spaced at distances of 3.5 $\mathrm{mm}$ at midshaft. There is a suggestion of midflank swellings. The inner ventrolateral tubercles are approximately evenly spaced at distances of 3.5-4 $\mathrm{mm}$ at midshaft. The outer ventrolateral tubercles are smaller but show the same distribution as the inner ventrolateral tubercles, with an outer ventrolateral tubercle generally occurring alongside an inner ventrolateral tubercle.

DisCUSSION: Discoscaphites minardi, n.sp. is very similar to $D$. iris (figs. $15 \mathrm{~A}, \mathrm{~B}, \mathrm{G}-\mathrm{O}$, $17 \mathrm{~A}-\mathrm{G})$. The main differences are (1) the flanks of the body chamber in D. minardi are nearly flat and subparallel, whereas they are usually broadly rounded in D. iris; (2) the midflank swellings are weak and radial in $D$. minardi, if they are present at all, whereas they are usually well developed and pointed in D. iris; and (3) the inner ventrolateral tubercles in $D$. minardi are radially elongated, whereas they are usually pointed in D. iris.

Discoscaphites minardi also resembles $D$. conradi in its general shape and ornament (fig. $17 \mathrm{~N}-\mathrm{V}$ ). However, the holotype of $D$. conradi (ANSP 51551) from the Prairie Bluff Chalk, Alabama, illustrated by Jeletzky and Waage (1978: pl. 1, figs. 1-4), is larger and covered with six rows of tubercles. Cobban and Kennedy (1995) characterized $D$. conradi as a highly variable species, but none of the specimens they illustrated from the Prairie Bluff Chalk of Alabama and Mississippi matches D. minardi. Landman and Waage (1993) stated that macroconchs of $D$. conradi usually have six to eight rows of tubercles and that microconchs usually have four to seven rows of tubercles; again, however, none of the specimens they illustrated from the Fox Hills Formation of South Dakota matches $D$. minardi. Specimens of $D$. conradi from the Severn Formation near Brightseat, Prince Georges County, Maryland, which is only approximately $85 \mathrm{~km}$ from the type locality of $D$. minardi, also bear little resemblance to $D$. minardi (fig. 17N-V; Kennedy et al., 1997: fig. 20B-J).

In contrast, the specimen called $D$. conradi ?conradi (Morton) (USNM 250607) figured by Jeletzky and Waage (1978: pl. 3, figs. 16, 17) from the Prairie Bluff Chalk of Alabama is very similar to $D$. minardi. This fact suggests that a bed-by-bed collection of scaphites from the Prairie Bluff Chalk may reveal $D$. minardi in the upper beds. In addition, Kennedy and Cobban (1993, fig. 6g-m) documented specimens of $D$. conradi from the Corsicana Formation of northeast Texas that are slender and some of which are close to D. minardi. However, the outer ventrolateral tubercles in all of these specimens are more closely spaced than the inner ones, whereas in D. minardi the tubercle spacing is approximately the same in both rows. 
The Kemp Clay at the top of the Corsicana Formation of northeast Texas contains Discoscaphites roanensis Stephenson, 1941 (Stephenson, 1941: 428, pl. 90, figs. 1-4), which Jeletzky and Waage (1978) synonymized with $D$. conradi. The holotype of $D$. roanensis (USNM 77310), a nearly complete macroconch, is similar to D. minardi in its general form but has three rows of flank tubercles, one of which first appears on the hook. The eight paratypes of $D$. roanensis are all fragments and comprise parts of the body chambers of three macroconchs and five microconchs. USNM 77311, the figured paratype, is part of the body chamber of a macroconch. It resembles $D$. minardi in the number of rows of tubercles, but the outer ventrolateral tubercles are more closely spaced that the inner ones.

There are several odd specimens in our collection that we provisionally retain in $D$. minardi. AMNH 47290 (fig. 19D-G) shows a difference in the number of tubercle rows from one side of the specimen to the other. The left side shows four rows conforming to D. minardi, whereas the right side shows five rows with the two flank rows disposed on either side of midwhorl height, more closely resembling $D$. conradi. Supernumerary tubercles occur in two other specimens. A single tubercle occurs between the inner and outer ventrolateral rows of tubercles in AMNH 50542 (fig. 18S-U), and two very faint swellings occur in addition to the midflank swellings on the right side just dorsal of the row of inner ventrolateral tubercles in AMNH 47292 (fig. 19b-e). This variation in tubercle number may be due to pathology or may indicate that the number of tubercle rows is not absolutely fixed in this species.

OCCURRENCE: Severn Formation, Kent County, Maryland; upper part of the New Egypt Formation, northeastern Monmouth County, New Jersey (Landman et al., in prep. a). Questionable specimens of this species have also been recovered from the top of the Tinton Formation and as reworked material at the base of the Hornerstown Formation near Freehold, central Monmouth County, New Jersey (Landman et al., in prep. b). This species denotes the D. minardi Zone on the Atlantic Coastal Plain, which represents the middle part of the upper Maastrichtian, cor- responding to the upper part of calcareous nannofossil Subzone CC26a and the lower part of Subzone CC26b.

\section{Discoscaphites cf. $D$. minardi, new species} Figure 15E, F

MATERial: A single specimen (USNM 525324) from the Severn Formation, Round Bay, Anne Arundel County, Maryland.

DESCRIPTION: USNM 525324 is the ventral part of a body chamber approximately 34 $\mathrm{mm}$ in diameter with the dorsal part still attached to the matrix (fig. 15E, F). The flanks are broadly rounded to flat, the ventrolateral shoulder is fairly abruptly rounded, and the venter is broadly rounded. The ornament is better preserved on the left side. Broad, rounded, evenly spaced ribs terminate in elongate inner ventrolateral tubercles on the adapical half of the specimen. These tubercles are much more pointed on the right side. The distance between the two most adoral tubercles is $6.5 \mathrm{~mm}$. Midflank tubercles are represented by slight elevations on the broad, rounded ribs. A few outer ventrolateral tubercles are present. Both inner and outer ventrolateral tubercles disappear on the hook, which is ornamented with fine, straight prorsiradiate ribs.

DiscUSSION: The presence of weak midflank tubercles in addition to rows of inner and outer ventrolateral tubercles suggests that this specimen is closely related to Discoscaphites minardi, n.sp. However, it is too incomplete for positive identification.

OCCURRENCE: Severn Formation, Round Bay, Anne Arundel County, Maryland.

\section{Discoscaphites sp.}

MATERIAL: USNM 525331 from the Severn Formation, Round Bay, Maryland.

DESCRIPTION: USNM 525331 is the ventral part of the adoral half of a body chamber (not illustrated). It is badly worn but preserves rows of inner and outer ventrolateral tubercles. The tubercles in each row are widely spaced at approximately equal intervals of 6$8 \mathrm{~mm}$.

OCCURRENCE: Severn Formation, Round Bay, Anne Arundel County, Maryland. 


\section{ACKNOWLEDGMENTS}

We thank many people who contributed to this study: William A. Cobban (U.S. Geological Survey, Denver), William J. Kennedy (University Museum, Oxford), Herbert Klinger (South African Museum, Cape Town), and Neal L. Larson (Black Hills Museum of Natural History, Hill City, South Dakota) reviewed an early draft of this manuscript and made many helpful suggestions; Jean SelfTrail (U.S. Geological Survey, Reston) examined samples from Maryland and North Carolina for nannofossils; W. Burleigh Harris (University of North Carolina, Wilmington) supplied information about the Peedee Formation; Don Clements (Rocky Point, NC) and Ned Gilmore (ANSP) donated specimens from the Peedee Formation to the AMNH; Harry Mendryk (New York) helped in the field, donated specimens, and freely shared his ideas; Susan Klofak (AMNH) helped in the field, prepared specimens, and drew sutures; Kathy Sarg (AMNH) helped in the field, did the sedimentological analysis, and helped prepare the figures; Bushra Hussaini (AMNH) helped in the field; Steve Thurston (AMNH) photographed the specimens and helped prepare the figures; Colleen McCartan (U.S. Geological Survey, Reston) prepared the dinoflagellate samples; Dan Kuehne (deceased, Merchantville, NJ) helped in the field; and Stephanie Crooms (AMNH) word processed the manuscript.

\section{REFERENCES}

Alberti, G. 1959. Zur Kenntnis der Gattung Deflandrea Eisenack (Dinoflag.) in der Kreide und im Alttertiär Nord- und-Mitteldeutschland. Mitteilungen des Geologischen Staatsinstitut Hamburg: 28: 93-105.

Arkhangelsky, A.D. 1912. Cretaceous deposits of east European Russia. Materialien zur Geologie Russlands 25: 1-631.

Baird, D. 1986. Upper Cretaceous reptiles from the Severn Formation of Maryland. Mosasaur 3: 63-85.

Benson, D.G., Jr. 1976. Dinoflagellate taxonomy and biostratigraphy at the Cretaceous-Tertiary boundary, Round Bay, Maryland. Tulane Studies in Geology and Paleontology 12(4): 169233.

Berggren, W.A. 1964. The Maestrichtian, Danian and Montian Stages and the Cretaceous-Tertia- ry boundary. Stockholm Contributions in Geology 11(5): 103-176.

Berggren, W.A., D.V. Kent, C.C. Swisher III, and M.-P. Aubry. 1995. A revised Cenozoic geochronology and chronostratigraphy. In W.A. Berggren and J. Hardenbol (editors), Geochronology, time scales and global stratigraphic correlation, SEPM Special Publication 54: 130212. Tulsa, OK: Society for Sedimentary Geology.

Black, M., and B. Barnes. 1959. The structure of coccoliths from the English Chalk. Geological Magazine 96(5): 321-328.

Bramlette, M.N., and E. Martini. 1964. The great change in calcareous nannoplankton fossils between the Maestrichtian and Danian. Micropalaeontology 10: 291-322.

Brenner, G.J. 1992. Palynological analyses of selected core samples from KEN-BF 180. Maryland Geological Survey Open-File Report 9-027, appendix C: 27-30.

Brouwers, E.M., and J.E. Hazel. 1978. Ostracoda and correlation of the Severn Formation (Navarroan; Maestrichtian) of Maryland. SEPM Paleontological Monograph 1: 1-52.

Brunnschweiler, R.O. 1966. Upper Cretaceous ammonites from the Carnarvon Basin of Western Australia. 1. The heteromorph Lytoceratina. Bureau of Mineral Resources Geology and Geophysics Bulletin (Canberra) 58: 1-58.

Bukry, D. 1969. Upper Cretaceous coccoliths from Texas and Europe. The University of Kansas Paleontological Contributions, Article 51(Protista 2): 1-79.

Burnett, J.A. 1998a. Upper Cretaceous. In P.R. Brown (editor), Calcareous nannofossil biostratigraphy: 132-199. London: Chapman and Hall.

Burnett, J.A. 1998b. New taxa and new combinations of Cretaceous nannofossils. Journal of Nannoplankton Research 19: 133-146.

Christensen, W.K. 1996. A review of the Upper Campanian and Maastrichtian belemnite biostratigraphy of Europe. Cretaceous Research 17: 751-766.

Clark, W.B. 1916. The Upper Cretaceous deposits of Maryland. In W.B. Clark et al., Upper Cretaceous. Maryland Geological Survey Systematic Report 6(1): 23-110. Baltimore: Johns Hopkins University Press.

Clark, W.B., R.M. Bagg, and G.B. Shattuck. 1897. Upper Cretaceous formations of New Jersey, Delaware and Maryland. Geological Society of America Bulletin 8: 315-358.

Cobban, W.A., and W.J. Kennedy. 1992. The last Western Interior Baculites from the Fox Hills Formation of South Dakota. Journal of Paleontology 66(4): 682-684. 
Cobban, W.A., and W.J. Kennedy. 1995. Maastrichtian ammonites chiefly from the Prairie Bluff Chalk in Alabama and Mississippi. Paleontological Society Memoir 44: 1-40.

Collignon, M. 1952. Ammonites néocrétacées du Menabe (Madagascar). II. Les Pachydiscidae. Travaux du Bureau Géologique de Madagascar 41: $1-114$.

Collignon, M. 1971. Atlas des fossiles caractéristiques de Madagascar (Ammonites). XVII. (Maestrichtien). Tananarive: Service Géologique.

Conrad, T.A. 1857. Descriptions of Cretaceous and Tertiary fossils. In W.H. Emory (editor), Report on the United States and Mexican boundary survey. United States 34th Congress, 1st Session, Senate Ex Document 108 and House Ex Document 135 1(2): 141-174.

Conrad, T.A. 1858. Observations on a group of Cretaceous fossil shells found in Tippah County, Mississippi, with descriptions of fifty-six new species. Journal of the Academy of Natural Sciences of Philadelphia, 2nd ser., 3: 323-336.

Cooke, C.W. 1952. Cretaceous system. In The geology and water resources of Prince Georges County, Maryland. Maryland Department of Geology, Mines and Water Resources Bulletin 10: 2-19.

Cookson, I.C. 1965. Microplankton from the Paleocene Pebble Point Formation, south-western Victoria. Proceedings of the Royal Society of Victoria 78: 137-141.

Cookson, I.C., and A. Eisenack. 1960. Microplankton from Australian Cretaceous sediments. Micropaleontology 6(1): 1-18.

Cookson, I.C., and A. Eisenack. 1962. Additional microplankton from Australian Cretaceous sediments. Micropaleontology 8(4): 485-507.

Corradini, D. 1973. Non-calcareous microplankton from the Upper cretaceous of the northern Apennines. Bollettino della Società Paleontologica Italiana 11: 119-197.

Crick, G.C. 1924. On Upper Cretaceous Cephalopoda from Portuguese East Africa. In E.O. Teale (editor), The geology of east Africa between the Zambesi and Sabie Rivers. Transactions of the Geological Society of South Africa 26: $130-140$.

Davey, R.J., C. Downie, W.A.S. Sarjeant, and G.L. Williams. 1969. Generic realocation. In R.J. Davey, C. Downie, W.A.S. Sarjeant, and G.L. Williams, Appendix to "Studies on Mesozoic and Cainozoic dinoflagellate cysts." Bulletin of the British Museum (Natural History). Geology. Appendix to Supplement 3: 1517.

Davey, R.J., and G.L. Williams. 1966. V. The genus Hystrichosphaeridium and its allies, In R.J.
Davey, C. Downie, W.A.S. Sarjaent, and G.L. Williams, Studies on Mesozoic and Cainozoic dinoflagellate cysts. Bulletin of the British Museum (Natural History). Geology. Supplement 3: 53-106.

Deflandre, G. 1963. Sur les Microrhabdulidés, famille nouvelle de nannofossiles calcaires. Comptes Rendus (Hebdomadaires des Séances) de l'Académie des Sciences, Paris 256: 34843487.

Deflandre, G., and I.C. Cookson. 1955. Fossil microplankton from Australian Late Mesozoic and Tertiary sediments. Australian Journal of Marine and Freshwater Research 6(2): 242313.

Deflandre, G., and C. Fert. 1954. Observations sur les coccolithophoridés actuels et fossils en microscopie ordinaire et électronique. Annales de Paléontologie 40: 115-176.

Edwards, L.E., G.S. Gohn, J.M. Self-Trail, D.C. Prowell, L.M. Bybell, L.P. Bardot, J.V. Firth, B.T. Huber, N.O. Frederiksen, and K.G. MacLeod. 1999. Physical stratigraphy, paleontology, and magnetostratigraphy of the USGSSantee Coastal Reserve core (CHN-803), Charleston County, South Carolina. United States Geological Survey Open-File Report 990308-A: 1-36.

Edwards, L.E., D.K. Goodman, and R.J. Witmer. 1984. Lower Tertiary (Pamunkey Group) dinoflagellate biostratigraphy, Potomac River area, Virginia and Maryland, In N. O. Frederiksen and K. Krafft (editors), Cretaceous and Tertiary stratigraphy, paleontology, and structure, southwestern Maryland, and northeastern Virginia. American Association of Stratigraphic Palynologists Field Trip Volume and Guidebook: 137-152.

Ehrenberg, C.G. 1838. Über das Massenverhältniss der jetzt lebenden Kiesel-Infusorien und über neues Infusorien-Conglomerat als Polierschiefer von Jastraba in Ungarn. Königlich Akademie der Wissenshaften zu Berlin, Abhandlungen 1836 1: 109-135.

Eisenack, A. 1954. Mikrofossilien aus Phosphoriten des samländischen Unteroligozäns und über Einheitlichkeit der Hystrichosphaerideen. Palaeontographica, Abteilung A 105: 49-95.

Eisenack, A., and H. Gocht. 1960. Neue Namen für einige Hystrichosphären der Bernsteinformation Ostpreussens. Neues Jahrbuch für Geologie und Paläontologie Monatschefte 1960(11): 511-518.

Faujas-Saint-Fond, B. 1799. Histoire naturelle de la montagne de Saint-Pierre de Maastricht. Paris: H.H. Jansen.

Firth, J.V. 1987. Dinoflagellate biostratigraphy of the Maastrichtian to Danian interval in the U.S. 
Geological Survey Albany core, Georgia, U.S.A. Palynology 11: 199-216.

Forbes, E. 1846. Report on the fossil Invertebrata from southern India, collected by Mr. Kaye and Mr. Cunliffe. Transactions of the Geological Society of London, ser. 7: 97-174.

Gallagher, W.B. 1986. Depositional environments, paleooceanography, and paleoecology of the Upper Cretaceous-Lower Tertiary sequence in the New Jersey Coastal Plain. In R. Talkington (editor), Geological investigations of the Coastal Plain of southern New Jersey. Part 2. B. Paleontologic investigations: 1-17. 2nd Annual Meeting of the Geological Association of New Jersey, Stockton State College, Pomona, New Jersey.

Gallagher, W.B. 1991. Selective extinction and survival across the Cretaceous/Tertiary boundary in the northern Atlantic Coastal Plain. Geology 19: 967-970.

Gallagher, W.B. 1993. The Cretaceous/Tertiary mass extinction event in the northern Atlantic Coastal Plain. Mosasaur 5: 75-155.

Gallagher, W.B., and D.C. Parris. 1985. Biostratigraphic succession across the Cretaceous-Tertiary boundary at the Inversand Company Pit, Sewell, N.J. In R. Talkington (editor), Geological investigations of the Coastal Plain of southern New Jersey. Part 1: Field Guide: C1-C16. 2nd Annual Meeting of the Geological Association of New Jersey, Stockton State College, Pomona, New Jersey.

Gallagher, W.B., D.C. Parris, and E.E. Spamer. 1986. Paleontology, biostratigraphy, and depositional environments of the Cretaceous-Tertiary transition in the New Jersey Coastal Plain. Mosasaur 3: 1-35.

Gardner, J.A. 1916. Upper Cretaceous systematic paleontology: Mollusca. In W.B. Clark et al., Upper Cretaceous. Maryland Geological Survey Systematic Report 6(1-2): 371-733. Baltimore: Johns Hopkins University Press.

Gartner, S. 1968. Coccoliths and related calcareous nannofossils from Upper Cretaceous deposits of Texas and Arkansas. The University of Kansas Paleontological Contributions, Article 48 (Protista 1): 1-56.

Gill, T. 1871. Arrangement of the families of mollusks. Smithsonian Miscellaneous Collections 227: 1-49.

Glaser, J.D. 1968. Coastal Plain geology of southern Maryland. Maryland Geological Survey Guidebook No. 1: 1-56.

Gocht, H. 1970. Dinoflagellaten-Zysten aus einem Geschiebefeuerstein und ihr Erhaltungszustand. Neues Jahrbuch für Geologie und Paläontologie Monatshefte 1970(3): 129-140.

Gohn, G.S. 1992. Distribution of selected ostra- code species in the Cretaceous part of corehole KEN-BF 180: a preliminary list. Maryland Geological Survey Open-File Report 93-02-7: 26, appendix B.

Górka, H. 1957. Les Coccolithophoridés du Maestrichtien supérieur de Pologne. Acta Palaeontologica Polonica 2: 239-284.

Grossouvre, A. de. 1894. Recherches sur la craie supérieure, 2, Paléontologie. Les ammonites de la Craie supérieure. Mémoires pour Servir à l'Explication de la Carte Géologique Détaillée de la France, 264 pp. [misdated 1893]

Habib, D., and W.S. Drugg. 1987. Palynology of sites 603 and 605, Leg 93, Deep Sea Drilling Project, In J.E. van Hinte, S.W. Wise, Jr., et al., Initial reports, Deep Sea Drilling Project 92(2): 751-776. Washington, DC: U.S. Government Printing Office.

Hansen, J.M. 1977. Dinoflagellate stratigraphy and echinoid distribution in Upper Maastrichtian and Danian deposits from Denmark. Bulletin of the Geological Society of Denmark 26: $1-26$.

Hansen, H.J. 1992. Stratigraphy of Upper Cretaceous and Tertiary sediments in a core-hole drilled near Chesterville, Kent County, Maryland. Maryland Geological Survey Open-File Report 93-02-7: 1-26.

Harland, R. 1973. Dinoflagellate cysts and acritarchs from the Bearpaw Formation (Upper Campanian) of southern Alberta, Canada. Palaeontology 16: 665-706.

Hartstein, E.F., and L.E. Decina. 1986. A new Severn Formation (early, middle Maastrichtian, Late Cretaceous) locality in Prince Georges County, Maryland. Mosasaur 3: 87-95.

Henderson, R.A., W.J. Kennedy, and K.J. McNamara. 1992. Maastrichtian heteromorph ammonites from the Carnovan Basin, Western Australia. Alcheringa 16: 133-170.

Hyatt, A. 1889. Genesis of the Arietidae. Smithsonian Contributions to Knowledge 26(637): 1239.

Hyatt, A. 1900. Cephalopoda. In K.A. von Zittel (editor), Textbook of palaeontology, translated by C.R. Eastman: 502-604. London: Macmillan.

Jansonius, J. 1986. Re-examination of Mesozoic Canadian dinoflagellate cysts published by S.A.J. Pocock (1962, 1972). Palynology 10: 201-223.

Jeletzky, J.A., and K.M. Waage. 1978. Revision of Ammonites conradi Morton, 1834, and the concept of Discoscaphites Meek, 1870. Journal of Paleontology 52(5): 1119-1132.

Jordan, R.R. 1963. Configuration of the Cretaceous-Tertiary boundary in the Delmarva Pen- 
insula and vicinity. Southeastern Geology 4: 187-198.

Jordan, R.R. 1976. The Cretaceous-Tertiary boundary in Delaware. In A.M. Thompson (editor), Guidebook to the stratigraphy of the Atlantic Coastal Plain in Delaware: 74-80. Third Annual Field Trip. Petrology Exploration Society of New York.

Kellum, L.B. 1962. Upper Cretaceous Mollusca from Niobrara County, Wyoming. Papers of the Michigan Academy of Science, Arts and Letters 47: 37-81.

Kennedy, W.J. 1986. The ammonite fauna of the Calcaire à Baculites (Upper Maastrichtian) of the Cotentin Peninsula (Manche, France). Palaeontology 29: 25-83.

Kennedy, W.J. 1987. The ammonite fauna of the type Maastrichtian with a revision of Ammonites colligatus Binkhorst, 1861. Bulletin de l'Institut Royal des Sciences Naturelles de Belgique 56: 151-267 (1986 imprint).

Kennedy, W.J., M. Bilotte, B. Lepicard, and F. Segura. 1986. Upper Campanian and Maastrichtian ammonites from the Petites Pyrénées, southern France. Eclogae Geologicae Helvetiae 79: 1001-1037.

Kennedy, W.J., and W.A. Cobban. 1993. Maastrichtian ammonites from the Corsicana Formation in northeast Texas. Geological Magazine 130: 57-67.

Kennedy, W.J., and W.A. Cobban. 1996. Maastrichtian ammonites from the Hornerstown Formation in New Jersey. Journal of Paleontology 70(5): 798-804.

Kennedy, W.J., and W.A. Cobban. 2000. Maastrichtian (Late Cretaceous) ammonites from the Owl Creek Formation in northeastern Mississippi, U.S.A. Acta Geologica Polonica 50(1): 175-190.

Kennedy, W.J., W.A. Cobban, and N.H. Landman. 1997. Maastrichtian ammonites from the Severn Formation of Maryland. American Museum Novitates 3210: 1-30.

Kennedy, W.J., A.S. Gale, and T.A. Hansen. 2001. The last Maastrichtian ammonites from the Brazos River sections in Falls County, Texas. Cretaceous Research 22: 163-171.

Kennedy, W.J., R.O. Johnson, and W.A. Cobban. 1995. Upper Cretaceous ammonite faunas of New Jersey. In J.E.B. Baker (editor), Contributions to the paleontology of New Jersey 12: 24-55. Geological Association.

Kennedy, W.A., N.H. Landman, W.K. Christensen, W.A. Cobban, and J.M. Hancock. 1998. Marine connections in North America during the late Maastrichtian: palaeogeographic and palaeobiogeographic significance of Jeletzkytes nebrascensis Zone cephalopod fauna from the
Elk Butte Member of the Pierre Shale, SE South Dakota and NE Nebraska. Cretaceous Research 19: 745-775.

Kennedy, W.J., N.H. Landman, and W.A. Cobban. 1996. The Maastrichtian ammonites Coahuilites sheltoni Böse, 1928 and Sphenodiscus pleurisepta (Conrad, 1857), from the uppermost Pierre Shale and basal Fox Hills Formation of Colorado and Wyoming. American Museum Novitates 3186: 1-14.

Kennedy, W.J., N.H. Landman, W.A. Cobban, and R.O. Johnson. 2000. Additions to the ammonite fauna of the Upper Cretaceous Navesink Formation of New Jersey. American Museum Novitates 3306: 1-30.

Klinger, H.C. 1976. Cretaceous heteromorph ammonites from Zululand. Memoirs of the Geological Survey of South Africa 69: 1-142.

Klinger, H.C., E.G. Kauffman, and W.J. Kennedy. 1980. Upper Cretaceous ammonites and inoceramids from the off-shore Alphard Group of South Africa. Annals of the South African Museum 82: 293-320.

Klinger, H.C., and W.J. Kennedy. 1993. Cretaceous faunas from Zululand and Natal, South Africa. The heteromorph ammonite genus $\mathbf{E u}$ baculites Spath, 1926. Annals of the South African Museum 102: 185-264.

Klinger, H.C., and W.J. Kennedy. 2001. Stratigraphic and geographic distribution, phylogenetic trends and general comments on the ammonite family Baculitidae Gill, 1871 (with an annotated list of species referred to the family). Annals of the South African Museum 107: 1290.

Klinger, H.C., W.J. Kennedy, J.A. Lees, and S. Kitto. 2001. Upper Maastrichtian ammonites and nannofossils and a Palaeocene nautiloid from Richards Bay, Kwa Zulu, South Africa. Acta Geologica Polonica 51: 273-291.

Kuehne, D.F. 1999. Upper Cretaceous macroinvertebrate faunas of the northern Atlantic Coastal Plain. Mosasaur 7: 29-79.

Kullmann, J., and J. Wiedmann. 1970. Significance of sutures in phylogeny of Ammonoidea. University of Kansas Paleontological Contributions 44: 1-32.

Lamarck, J.P.B. de M. de. 1799. Prodrome d'une nouvelle classification des coquilles. Mémoires de la Société d'Histoire Naturelle de Paris; 1799: 63-90.

Lamarck, J.P.B. de M. de. 1801. Système des animaux sans vertèbres. Deterville, Paris: The author.

Landman, N.H., and W.A. Cobban. 2003. Ammonites from the upper part of the Pierre Shale and Fox Hills Formation of Colorado. American Museum Novitates 3388: 1-45. 
Landman, N.H., R.O. Johnson, and L.E. Edwards. In prep. a. Cephalopods from the Cretaceous/ Tertiary boundary interval on the Atlantic Coastal Plain, with a description of the highest ammonite zones in North America. Part II. Northeastern Monmouth County, New Jersey.

Landman, N.H., R.O. Johnson, M. Garb, and L.E. Edwards. In prep. b. Cephalopods from the Cretaceous/Tertiary boundary interval on the Atlantic Coastal Plain, with a description of the highest ammonite zones in North America. Part III. Manasquan Basin, Monmouth County, New Jersey.

Landman, N.H., R.O. Johnson, M. Garb, and L.E. Edwards. In prep. c. Cephalopods from the Cretaceous/Tertiary boundary interval on the Atlantic Coastal Plain, with a description of the highest ammonite zones in North America. Part IV. Crosswicks Creek Basin, Monmouth County, New Jersey.

Landman, N.H., and K.M. Waage. 1993. Scaphitid ammonites of the Upper Cretaceous (Maastrichtian) Fox Hills Formation in South Dakota and Wyoming. Bulletin of the American $\mathrm{Mu}-$ seum of Natural History 215: 1-257.

Larson, N.L., S.D. Jorgensen, R.A. Farrar, and P.L. Larson. 1997. Ammonites and the other cephalopods of the Pierre Seaway. Tucson, AZ: Geoscience Press.

Lejeune-Carpentier, M. 1938. L'étude microscopique des silex. Areoligera: nouveau genre d'Hystrichosphaeridée (sixième note). Annales de la Société Géologique de Belgique 62: B163-B174.

Lejeune-Carpentier, M. 1942. L'étude microscopique des silex. Péridiniens nouveaux ou peu connnus (dixième note). Annales de la Société Géologique de Belgique 65: B181-B192.

Lentin, J.K., and G.L. Williams. 1973. Fossil dinoflagellates; index to genera and species. Geological Survey of Canada Paper 73-42: 1-176.

Lentin, J.K., and G.L. Williams. 1976. A monograph of fossil peridinoid dinoflagellate cysts. Bedford Institute of Oceanography Report Series BI-R-75-16: 1-237.

Lentin, J.K., and G.L. Williams. 1977. Fossil dinoflagellate genus Isabelidinium nom. nov. Palynology 1: 167-168.

May, F.E. 1980. Dinoflagellate cysts of the Gymnodiniaceae, Peridiniaceae, and Gonyaulacacaeae from the Upper Monmouth Group, Atlantic Highlands, New Jersey. Palaeontographica Abteilung B 172: 10-116.

Meek, F.B. 1870. A preliminary list of fossils, collected by Dr. Hayden in Colorado, New Mexico, and California, with brief descriptions of a few of the new species. Proceedings of the American Philosophical Society 11: 425-431.
Meek, F.B. 1871. Preliminary paleontological report, consisting of lists of fossils, with descriptions of some new types, etc. Preliminary Report of the United States Geological Survey of Wyoming (Hayden) 4: 287-318.

Meek, F.B. 1876. A report on the invertebrate Cretaceous and Tertiary fossils of the upper Missouri country. United States Geological Survey of the Territories (Hayden) Report 9: 1-629.

Minard, J.P. 1974. Geology of the Betterton Quadrangle, Kent County, Maryland, and a discussion of the regional stratigraphy. United States Geological Survey Professional Paper 816: 127.

Minard, J.P. 1980. Geology of the Round Bay quadrangle, Anne Arundel County, Maryland. United States Geological Survey Professional Paper 1109: 1-30.

Minard, J.P., J.P. Owens, N.F. Sohl, H.E. Gill, and J.F. Mello. 1969. Cretaceous-Tertiary boundary in New Jersey, Delaware, and eastern Maryland. United States Geological Survey Bulletin 1274-H: 1-33.

Minard, J.P., N.F. Sohl, and J.P. Owens. 1977. Reintroduction of the Severn Formation (Upper Cretaceous) to replace the Monmouth Formation in Maryland. United States Geological Survey Bulletin 1435-A: 132-133.

Morgenroth, P. 1968. Zur Kenntnis der Dinoflagellaten und Hystrichosphaeridien des Danien. Geologisches Jarhbuch, Hannover 86: 533-578.

Morton, S.G. 1834. Synopsis of the organic remains of the Cretaceous group of the United States. Illustrated by nineteen plates, to which is added an appendix containing a tabular view of the Tertiary fossils hitherto discovered in North America. Philadephia: Key and Biddle.

Murray, G.E. 1961. Geology of the Atlantic and Gulf Coastal Province of North America. New York: Harper.

Noël, D. 1970. Coccolithes Crétacés: La Craie Campanienne du Bassin de Paris. Paris: Éditions du Centre National de la Recherche Scientifique.

Olsson, R.K. 1963. Latest Cretaceous and earliest Tertiary stratigraphy of New Jersey Coastal Plain. American Association of Petroleum Geologists Bulletin 47(4): 643-665.

Olsson, R.K. 1975. Upper Cretaceous and Lower Tertiary stratigraphy, New Jersey coastal plain. New York, NY: Petroleum Exploration Society.

Olsson, R.K. 1992. Foraminiferal analyses of selected core samples from KEN-BF 180. Maryland Geological Survey Open-File Report 9302-7: 31-33, appendix D.

Olsson, R.K., T.G. Gibson, H.H. Hansen, and J.P. Owens. 1988. Geology of the northern Atlantic Coastal Plain: Long Island to Virginia. In R.E. 
Sheridan and J.A. Grow (editors), The Atlantic continental margin: U.S.: 87-106. Boulder, CO: Geological Society of America.

Olsson, R.K., C. Liu, and M. von Fossen. 1996. The Cretaceous-Tertiary catastrophic event at Millers Ferry, Alabama. In G. Ryder, D. Fastovsky, and S. Gartner (editors), The Cretaceous-Tertiary event and other catastrophes in earth history. Geological Society of America Special Paper 307: 263-277.

Olsson, R.K., and S.W. Wise. 1987. Upper Maestrichtian to Middle Eocene stratigraphy of the New Jersey slope and coastal plain. In J.E. van Hinte, S.W. Wise, Jr., et al., Initial reports, Deep Sea Drilling Project 92(2): 1343-1365. Washington, DC: U.S. Government Printing Office.

Orbigny, A. d'. 1847. Paléontologie. In D. d'Urville, Voyage au pole sud et dans l'Océanie sur les corvettes l'Astrolabe et la Zélée, exécuté par ordre du roi pendant les années 1837-18381839-1840, sous le commandement de M. J. Dumont d'Urville, capitaine de vaisseau .... Paris: Gide, 1842-1854.

Owen, D.D. 1852. Report of a geological survey of Wisconsin, Iowa, and Minnesota and incidentally of a portion of Nebraska Territory. Philadelphia: Lippincott, Grambo.

Owens, J.P., J.P. Minard, N.F. Sohl, and J.F. Mello. 1970. Stratigraphy of the outcropping post-Magothy Upper Cretaceous formations in southern New Jersey and northern Delmarva Peninsula, Delaware and Maryland. United States Geological Survey Professional Paper 674: 1-60.

Owens, J.P., N.F. Sohl, and J.P. Minard. 1977. A field guide to the Cretaceous and Lower Tertiary beds of the Raritan and Salisbury embayments, New Jersey, Delaware, and Maryland. American Association of Petroleum Geologists-Society of Economic Paleontologists and Mineralogists, Annual Meeting, Washington, D.C.: $1-57$.

Palamarczuk, S., J.A. Chamberlain, Jr., and D.O. Terry, Jr. 2003. Dinoflagellates of the Fox Hills Formation (Maastrichtian), Badlands area of South Dakota: biostratigraphic and paleoenvironmental implications. Programs with Abstracts, Joint Meeting of the American Association of Stratigraphic Palynology, Canadian Association of Palynologists, and the North American Micropaleontology Section of the SEPM, St. Catharines, Canada, Oct. 5-8, 2003. [not paginated]

Perch-Nielsen, K. 1968. Der Feinbau und die Klassifikation der Coccolithen aus dem Maastrichtien von Dänemark. Det Kongelige Danske videnskabernes selskab biologiske skrifter 16 : 1-93.

Perch-Nielsen, K. 1973. Neue Coccolithen aus dem Maastrichtien von Dänemark, Madagaskar und Ägypten. Bulletin of the Geological Society of Denmark 22: 306-333.

Perch-Nielsen, K. 1985. Mesozoic calcareous nannofossils. In H.M. Bolli, J.B. Saunders, and K. Perch-Nielsen (editors), Plankton Stratigraphy: 329-426. Cambridge: Cambridge University Press.

Pessagno, Jr., E.A. 1969. Upper Cretaceous stratigraphy of the western Gulf coast area of México, Texas, and Arkansas. The Geological Society of America Memoir 111: 1-139.

Piveteau, J. 1952. Traité de paléontologie. Paris: Masson.

Reinhardt, P. 1965. Neue Familien für fossile Kalkflagellaten (Coccolithophoriden, Coccolithineen). Monatsberichte der Deutschen Akademie der Wissenschaften zu Berlin 7: 30-40.

Reinhardt, P. 1966. Zur Taxionomie und Biostratigraphie des fossilen Nannoplanktons aus dem Malm, der Kreide und dem Alttertiär mitteleuropas. Freiberger Forschungshefte C196: 5109.

Reinhardt, P. and H. Górka. 1967. Revision of some Upper Cretaceous Coccoliths from Poland and Germany. Neues Jahrbuch für Geologie und Paläontologie, Abhandlungen 129: 240-256.

Roncaglia, L., and D. Corradini. 1997. Correlation of key dinoflagellate events with calcareous nannoplankton and planktonic foraminiferal zones in the Solignano Formation (Maastrichtian, Late Cretaceous) northern Apennines, Italy. Review of Paleobotany and Palynology 97: 177-196.

Russell, E.E. 1975. Stratigraphy of the outcropping Upper Cretaceous in western Tennessee. In E.E. Russell and W.S. Parks (editors), Stratigraphy of the outcropping Upper Cretaceous, Paleocene and Lower Eocene in western Tennessee (including descriptions of younger fluvial deposits). State of Tennessee Department of Conservation/Division of Geology Bulletin 75: A1-A65.

Schiøler, P., H. Brinkhuis, L. Roncaglia, and G.J. Wilson. 1997. Dinoflagellate biostratigraphy and sequence stratigraphy of the type Maastrichtian (Upper Cretaceous), ENCI Quarry, The Netherlands. Marine Micropaleontology 31: 65-95.

Schiøler, P., and G.J. Wilson. 1993. Maastrichtian dinoflagellate zonation in the Dan Field, Danish North Sea. Review of Palaeobotany and Palynology 78: 321-351.

Schönfeld, J., and J. Burnett. 1991. Biostratigraphical correlation of the CampanianMaastrichtian boundary: Lägerdorf-Hemmoor (northwestern Germany), DSDP sites 548A, 
549 and 551 (eastern North Atlantic) with palaeobiogeographical and palaeoceanographical implications. Geological Magazine 128(5): 479-503.

Seunes, J. 1890. Contributions à l'étude des céphalopods du Crétacé Supérieur de France. 1. Ammonites du Calcaire à Baculites du Cotentin. Mémoires de la Société Géologique de France, Paléontologie 1, Mémoire 2: 1-7.

Shafik, S., and H. Stradner. 1971. Nannofossil from the Eastern Desert, Egypt. Jahrbuch der Geologischen Bundesanstalt, Sonderband 17: 69-104.

Slimani, H. 1994. Les dinokystes des craies du Campanien au Danien à Halembaye (Belgique) et à Beutenaken (Pays-Bas). Mémoires pour servir à l'explication des cartes géologique et minières de la Belgique 37: 1-173.

Smith, C.C., and E.A. Mancini. 1982. Biostratigraphy. In E.E. Russell et al., Upper Cretaceous in the lower Mississippi embayment of Tennessee and Mississippi: lithostratigraphy and biostratigraphy. Geological Society of America, Field Trip Guidebook: 15-26. 1982 Annual Meeting, New Orleans, LA.

Sohl, N.F. 1960. Archeogastropoda, Mesogastropoda and stratigraphy of the Ripley, Owl Creek, and Prairie Bluff Formations. United States Geological Survey Professional Paper 331-A: $1-151$.

Sohl, N.F. 1964. Neogastropoda, Opisthobranchia, and Basommatophora from the Ripley, Owl Creek, and Prairie Bluff Formations. United States Geological Survey Professional Paper 331-B: 153-344.

Sohl, N.F. 1977. Utility of gastropods in biostratigraphy. In E.G. Kauffman, and J.E. Hazel (editors), Concepts and methods of biostratigraphy: 519-539. Stroudsburg, PA: Dowden, Hutchinson and Ross.

Sohl, N.F., and C.F. Koch. 1984. Upper Cretaceous (Maestrichtian) larger invertebrates from the Haustator bilira Asssemblage Zone in the Atlantic Coastal Plain with further data for the east Gulf. United States Geological Survey Open File Report 87-194: 1-172.

Sohl, N.F., and J.P. Owens. 1991. Cretaceous Stratigraphy of the Carolina Coastal Plain. In J.W. Horton, Jr., and V.A. Zullo (editors), The geology of the Carolinas: 191-220. Knoxville: University of Tennessee Press.

Spath, L.F. 1926. New ammonites from the English Chalk. Geological Magazine 63: 77-83.

Spath, L.F. 1960. On Upper Cretaceous (Maastrichtian) Ammonoidea from Western Australia. Journal of the Royal Society of Western Australia 26: 41-57.

Stephenson, L.W. 1923. The Cretaceous formation of North Carolina, part 1, Invertebrate fossils of the Upper Cretaceous formations. North Carolina Geological Survey 5: 1-604.

Stephenson, L.W. 1941. The larger invertebrates of the Navarro Group of Texas (exclusive of corals and crustaceans and exclusive of the fauna of the Escondido Formation). University of Texas Bulletin 4101: 1-641.

Stephenson, L.W. 1955. Owl Creek (Upper Cretaceous) fossils from Crowley's Ridge, southeastern Missouri. United States Geological Survey Professional Paper 274: 97-140.

Stoliczka, F. 1863-1866. The fossil Cephalopoda of the Cretaceous rocks of southern India. Ammonitidae with revision of the Nautilidae etc. Memoirs of the Geological Survey of India. Palaeontologia. Indica 3 1(1863): 41-56; $2-$ 5(1864): 57-106; 6-9(1865): 107-154; 1013(1866): 155-216.

Stover, L.E., and W.R. Evitt. 1978. Analyses of pre-Pleistocene organic-walled dinoflagellates. Stanford University Publications 15: 1-300.

Stradner, H. 1963. New contributions to Mesozoic stratigraphy by means of nannofossils. Proceedings of the Sixth World Petroleum Congress, Section 1, Paper 4, 167-183.

Tuomey, M. 1856. Description of some new fossils from the Cretaceous rocks of the southern states. Proceedings of the Academy of Natural Sciences of Philadelphia 7: 167-172.

Vekshina, V.N. 1959. Coccolithophoridae of the Maastrichtian deposits of the West Siberian lowlands. Siberian Science Research Institute of Geology, Geophysics, Mineralogy and Raw Materials 2: 56-81.

Verbeek, J.W. 1977. Calcareous nannoplankton biostratigraphy of Middle and Upper Cretaceous deposits in Tunisia, southern Spain and France. Utrecht Micropaleontological Bulletins 16: $1-157$.

Wall, D. 1967. Fossil microplankton in deep-sea cores from the Caribbean Sea. Paleontology 10(1): 95-123.

Wedekind, R. 1916. Über Lobus, Suturallobus und Inzision. Zentralblatt für Mineralogie, Geologie und Paläontologie B 1916: 185-195.

Wetzel, O. 1933. Die in organischer Substanz erhaltenen Mikrofossilien des baltischen KreideFeuersteins mit einem sediment-petrographischen und stratigraphischen Anhang. Palaeontographica Abteilung A 78: 1-110.

Wheeler, W.H., and H.A. Curran. 1974. Relation of Rocky Point Member (Peedee Formation) to Cretaceous-Tertiary boundary in North Carolina. The American Association of Petroleum Geologists Bulletin 58(9): 1751-1757.

Whitfield, R.P. 1892. Gasteropoda and Cephalopoda of the Raritan Clays and Greensand Marls 
of New Jersey. United States Geological Survey Monograph 18: 1-402.

Whitney, B.L. 1984. Dinoflagellate biostratigraphy of the Maestrichtian-Danian section in southern Maryland. In N.O. Frederiksen and K. Krafft (editors), Cretaceous and Tertiary stratigraphy, paleontology, and structure, southwestern Maryland and northeastern Virginia. American Association of Stratigraphic Palynologists Field Trip Volume and Guidebook: 123-136.

Wiedmann, J. 1966. Stammesgeschichte und Sys- tem der posttriadischen Ammonoideen: ein Überblick. Neues Jahrbuch für Geologie und Paläontologie Abhandlungen 125: 49-79; 127: 13-81.

Young, G., and J. Bird. 1828. A geological survey of the Yorkshire coast: describing the strata and fossils occurring between the Humber and the Tees, from the German Ocean to the Plain of York, 2nd ed.: 1-368. Whitby: R. Kirby.

Zittel, K.A. von. 1884. Handbuch der Paläontologie, abt. I, band II: 329-522. Munich: R. Oldenbourg.

Recent issues of the Novitates may be purchased from the Museum. Lists of back issues of the Novitates and Bulletin published during the last five years are available at World Wide Web site http://library.amnh.org. Or address mail orders to: American Museum of Natural History Library, Central Park West at 79th St., New York, NY 10024. TEL: (212) 769-5545. FAX: (212) 7695009. E-MAIL: scipubs@amnh.org 